GILBERTO CARLOS SUNDEFELD JUNIOR

EFEITOS DO RECEBIMENTO DO LODO DA ESTAÇÃO DE TRATAMENTO DE ÁGUA PELO SISTEMA DE TRATAMENTO DE ESGOTO POR LODO ATIVADO EM BATELADAS E AERAÇÃO PROLONGADA DO MUNICÍPIO DE JUQUITIBA - SP 


\section{EFEITOS DO RECEBIMENTO DO LODO DA ESTAÇÃO DE TRATAMENTO DE ÁGUA PELO SISTEMA DE TRATAMENTO DE ESGOTO POR LODO ATIVADO EM BATELADAS E AERAÇÃO PROLONGADA DO MUNICÍPIO DE JUQUITIBA - SP}

\footnotetext{
Dissertação apresentada à Escola Politécnica da Universidade de São Paulo para obtenção do Grau de Mestre em Engenharia Civil

Área de concentração: Engenharia Civil Orientador: Prof. Livre-Docente Roque Passos Piveli
} 
Este exemplar foi revisado e alterado em relação à versão original, sob responsabilidade única do autor e com a anuência de seu orientador.

São Paulo, de junho de 2007.

Assinatura do autor

Assinatura do orientador

FICHA CATALOGRÁFICA

Sundefeld Júnior, Gilberto Carlos

Efeitos do recebimento do lodo da estação de tratamento de água pelo sistema de tratamento de esgoto por lodo ativado em bateladas e aeração prolongada do Município de Juquitiba - SP I G.C. Sundefeld Jr. -- ed.rev. -- São Paulo, 2007. $107 \mathrm{p}$.

Dissertação (Mestrado) - Escola Politécnica da Universidade de São Paulo. Departamento de Engenharia Hidráulica e Sanitária.

1. Lodo ativado 2. Estações de tratamento de água I. Universidade de São Paulo. Escola Politécnica. Departamento de Engenharia Hidráulica e Sanitária II. 2007. 


\section{AGRADECIMENTOS}

Agradeço aos meus familiares pela compreensão e apoio a mim prestado ao longo deste trabalho.

Ao meu orientador Prof. Livre docente Roque Passos Piveli pelas informações e experiências profissionais passadas que contribuíram para o desenvolvimento deste trabalho.

Aos técnicos do Laboratório de Saneamento Prof. Lucas Nogueira Garcez, Fábio e Laerte.

Aos bibliotecários da Biblioteca EP-Civil, USP.

Aos novos amigos funcionários da SABESP o Químico Osvaldo Beltrame Filho, que se esforçou tanto quanto eu para as realizações conquistadas, Crysthian Antunes operador da ETE e, seguidamente, encarregado dos sistemas de saneamento do município e João Laide Silva operador da ETA. Também ao Arlindo Bambi, Arlindo Soares, Ednir Lara de Pádua, Janethe Daneluz Silva, Márcio Rodrigues Cunha, Simião Rodrigues Fortes Filho e Waldecir Teodoro Garcia.

Às novas amigas Maria Aparecida Faustino Pires e Marycel Cotrim do Instituto de Pesquisas Energéticas e Nucleares - IPEN, pela contribuição prestada para o desenvolvimento deste estudo.

À FAPESP pela concessão da bolsa de mestrado através do processo 06/53000-4.

À FAPESP pelo fomento concedido à esta pesquisa através do Projeto Gerenciamento de Lodos de ETA's. Programa de Políticas Públicas, processo n०03/06419-1.

E aos colegas de pós-graduação Lúcia, Carlos, Luciano, Rui e Ricardo, os quais comigo dividiram o mesmo espaço no laboratório de saneamento. 


\section{RESUMO}

Existem algumas diferentes soluções técnicas de engenharia para a finalidade de tratamento e disposição final dos resíduos gerados em ETA's aplicáveis aos diferentes sistemas de tratamento de água. Porém, depara-se com estações consolidadas sem os sistemas de tratamento da fase sólida, onde nem sempre a melhor solução para o tratamento é a mais econômica ou ainda, é a possível de ser implantada. Com isso propôs-se neste estudo avaliar a capacidade da estação de tratamento de esgotos receber os resíduos da ETA, da cidade de Juquitiba - SP, via rede coletora de esgotos, uma vez que existe na ETE o sistema de tratamento dos sólidos ali gerados. Este estudo teve como objetivo verificar as transformações do fósforo e do nitrogênio ao longo do sistema de esgotos, verificar as variações das concentrações de DBO, DQO e sólidos em suspensão, assim como verificar se é possível a manutenção de um equilíbrio consistente controlado pela idade do lodo. $A$ estação de tratamento de água produz resíduos que resultariam em um acréscimo médio de $133 \mathrm{mg} / \mathrm{L}$ de sólidos no esgoto e ao longo deste estudo atingiu-se $74 \mathrm{mg} / \mathrm{L}$. Esta contribuição representou, aproximadamente, uma situação em que o porte da ETA é o dobro da ETE receptora dos resíduos. Como conseqüência as concentrações dos sólidos em suspensão totais nos reatores biológicos aumentaram em média $15 \%$ e no efluente tratado $73 \%$, ainda a produção de lodo biológico aumentou a ordem de $40 \%$. Ocorreu a diminuição da concentração de fósforo total no efluente tratado da ETE em $29 \%$ e $51 \%$ para os reatores 1 e 2 , respectivamente e da concentração de fósforo solúvel em $74 \%$ e $79 \%$ para os reatores 1 e 2 , respectivamente. Ocorreu a diminuição da remoção média de NKT em 18\% e na remoção média de $\mathrm{N}-\mathrm{NH}_{3}$ em 13\%. Ocorreu, ainda, a diminuição da remoção dos parâmetros DBO e DQO em 4\% após o lançamento do lodo da ETA no sistema de esgotos. Pode-se então admitir que ETE's pelo processo de lodo ativado com aeração prolongada e com reatores seqüenciais em bateladas são adequados para o recebimento de lodo proveniente de ETA's, desde que projetada para atender a essa função complementar, especialmente no que se refere às unidades de desidratação de lodo.

Palavras chaves: lodo ativado, lodo de ETA 


\begin{abstract}
There are different technical engineering solutions for the treatment and final disposal of water treatment plants (WTPs) residuals. Discharge of WTP residual to a wastewater treatment plant (WWTP) is a technical solution in evidence. Therefore, the purpose of this study was to evaluate the capacity of the WWTP using sequencing batch reactor (SBR) activated-sludge process (with two reactors named reactor 1 and 2) in the city of Juquitiba, State of São Paulo, to receive the WTP residuals by gravity sanitary sewers. For this purpose the following points were checked: phosphorous and nitrogen transformations in the sewer systems, variations in BOD, COD and suspended solids (SS) concentrations and the possibility of maintaining a consistent balance system controlled by solids retention time. There was an average increase of $74 \mathrm{mg}$ of suspended solids per liter in incoming sewage by the discharge of WTP residuals to sanitary sewers. Suspended solids concentrations in the biological reactors increased 15 percent in average and 73 percent in the final effluent. Production of waste activated-sludge increased by 40 percent. There was a decrease of 29 percent and 51 percent of total phosphorus concentration in the effluent in reactors 1 and 2, respectively, and of 74 percent and 79 percent of soluble phosphorus concentration in reactors 1 and 2, respectively. Total Kjeldahl nitrogen removal efficiency was reduced by 18 percent and ammonia nitrogen removal efficiency by 13 percent. BOD and DQO parameters for efficiency removal showed a decrease of 4 percent after the discharge of WTP residual to sanitary sewers. In view of these results it can be admitted that WWTPs using sequencing batch reactor activated-sludge process are suitable to receive WTP residuals since adequately designed for this complementary function.
\end{abstract}

Keywords: activated sludge, WTP residuals 


\section{LISTA DE FIGURAS}

Figura 3.1 - Captação de água bruta superficial para a ETA Juquitiba -SP ..............4

Figura 3.2 - Unidade de floculação da ETA Juquitiba - SP ...................................

Figura 3.3 - Unidade de decantação da ETA Juquitiba - SP .................................

Figura 3.4 - Unidades de filtração da ETA Juquitiba - SP ..................................

Figura 3.5 - Água de retro-lavagem dos filtros da ETA Juquitiba - SP ......................

Figura 3.6 - Descarga de lodo de ETA no corpo d'água ......................................10

Figura 3.7 - Fluxograma simplificado das fases líquida e sólida de uma ETA ..........12

Figura 3.8 - Esquema simplificado do sistema de lodo ativado de fluxo contínuo.....16

Figura 3.9 - Esquema simplificado do sistema de lodos ativados em bateladas.......16

Fugura 3.10 - Representação das quatro frações do material orgânico e seus destinos no processo de lodo ativado (Fonte: adaptado de Metcalf \& Eddy, 2003)..24 Figura 3.11 - Fluxograma esquemático da matéria orgânica em um sistema de lodo ativado. 26

Figura 3.12 - Situação do saneamento no Brasil (Fonte: adaptado de SNIS, 2002) 31

Figura 4.1 - Seqüência das unidades produtoras de água tratada do sistema de tratamento de água de Juquitiba: 1- estação de captação de água bruta; 2-

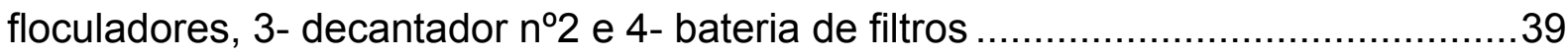

Figura 4.2 - Lavagem da unidade decantadora da ETA Juquitiba...........................40

Figura 4.3 - Pontos de coletas dos resíduos da ETA ..........................................42

Figura 4.4 - Estação de tratamento de esgotos pelo processo e lodo ativado com

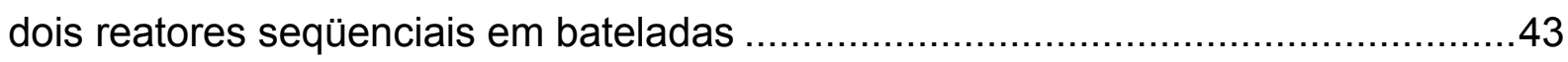

Figura 4.5 - Grade de remoção de sólidos grosseiros com limpeza manual ............44

Figura 4.6 - Pontos de coleta das amostras da ETE Juquitiba ..............................46

Figura 5.1 - Esquema de cálculo da aplicação dos resíduos da ETA na ETE, no dia da lavagem dos decantadores da ETA.

Figura 5.3 - Séries temporais de $\mathrm{DBO}_{5,20}$ do esgoto afluente e efluente da ETE Juquitiba, sem o lançamento do lodo da ETA no sistema de esgotos 60

Figura 5.4 - Séries temporais de DQO do esgoto afluente e efluente da ETE Juquitiba, sem o lançamento do lodo da ETA no sistema de esgotos 
Figura 5.5 - Séries temporais de sólidos em suspensão totais do lodo dos reatores biológicos 1 e 2 da ETE Juquitiba, sem o lançamento do lodo da ETA no sistema de esgotos.

Figura 5.6 - Séries temporais de sólidos em suspensão voláteis do lodo dos reatores biológicos 1 e 2 da ETE Juquitiba, sem o lançamento do lodo da ETA no sistema de esgotos.

Figura 5.7 - Séries temporais de sólidos em suspensão fixos do lodo dos reatores biológicos 1 e 2 da ETE Juquitiba, sem o lançamento do lodo da ETA no sistema de esgotos.

Figura 5.8 - Séries temporais de NKT do esgoto afluente e efluente da ETE Juquitiba, sem o lançamento do lodo da ETA no sistema de esgotos

Figura 5.9 - Séries temporais de nitrogênio amoniacal do esgoto afluente e efluente da ETE Juquitiba, sem o lançamento do lodo da ETA no sistema de esgotos 64

Figura 5.10 - Séries temporais de nitrato do esgoto afluente e efluente da ETE Juquitiba, sem o lançamento do lodo da ETA no sistema de esgotos

Figura 5.11 - Séries temporais de fósforo total do esgoto afluente e efluente da ETE Juquitiba, sem o lançamento do lodo da ETA no sistema de esgotos 66

Figura 5.12 - Séries temporais de fósforo solúvel do esgoto afluente e efluente da ETE Juquitiba, sem o lançamento do lodo da ETA no sistema de esgotos ...... 66

Figura 5.13 - Séries temporais de OD do lodo dos reatores biológicos 1 e 2 da ETE Juquitiba, sem o lançamento do lodo da ETA no sistema de esgotos 67 Figura 5.14 - Séries temporais de alcalinidade do esgoto afluente e tratado da ETE Juquitiba, sem o lançamento do lodo da ETA no sistema de esgotos 68 Figura 5.15 - Diagrama "box-plot" da eficiência de remoção de $\mathrm{DBO}_{5,20}$ do esgoto bruto pela ETE Juquitiba, sem o lançamento do lodo da ETA no sistema de esgotos

Figura 5.16 - Diagrama "box-plot" da eficiência de remoção de DQO do esgoto bruto pela ETE Juquitiba, sem o lançamento do lodo da ETA no sistema de esgotos 69 Figura 5.17 - Diagrama "box-plot" da eficiência de remoção de NKT do esgoto bruto pela ETE Juquitiba, sem o lançamento do lodo da ETA no sistema de esgotos .......70 Figura 5.18 - Diagrama "box-plot" da eficiência de remoção de nitrogênio amoniacal do esgoto bruto pela ETE Juquitiba, sem o lançamento do lodo da ETA no sistema de esgotos. 
Figura 5.19 - Diagrama "box-plot" da eficiência de remoção de fósforo total do esgoto bruto pela ETE Juquitiba, sem o lançamento do lodo da ETA no sistema de esgotos.

Figura 5.20 - Diagrama "box-plot" da eficiência de remoção de fósforo solúvel do esgoto bruto pela ETE Juquitiba, sem o lançamento do lodo da ETA no sistema de esgotos.

Figura 5.21 - Séries temporais de $\mathrm{DBO}_{5,20}$ do esgoto afluente e efluente da ETE Juquitiba, após o início do lançamento do lodo da ETA no sistema de esgotos 74 Figura 5.22 - Séries temporais de DQO do esgoto afluente e efluente da ETE Juquitiba, após o início do lançamento do lodo da ETA no sistema de esgotos

Figura 5.23 - Diagrama "Box-plot" de $\mathrm{DBO}_{5,20}$ do esgoto bruto e tratado da ETE Juquitiba, sem o lançamento do lodo da ETA no sistema de esgotos

Figura 5.24 - Diagrama "Box-plot" de $\mathrm{DBO}_{5,20}$ do esgoto bruto e tratado da ETE Juquitiba, após o início do lançamento do lodo da ETA no sistema de esgotos 75 Figura 5.25 - Séries temporais de sólidos em suspensão totais do lodo dos reatores biológicos 1 e 2 da ETE Juquitiba, após o início do lançamento do lodo da ETA no sistema de esgotos

Figura 5.26 - Séries temporais de sólidos em suspensão voláteis do lodo dos reatores biológicos 1 e 2 da ETE Juquitiba, após o início do lançamento do lodo da ETA no sistema de esgotos.

Figura 5.27 - Séries temporais de sólidos em suspensão fixos do lodo dos reatores biológicos 1 e 2 da ETE Juquitiba, após o início do lançamento do lodo da ETA no sistema de esgotos

Figura 5.28 - Séries temporais de NKT do esgoto afluente e efluente da ETE Juquitiba, após o início do lançamento do lodo da ETA no sistema de esgotos

Figura 5.29 - Séries temporais de nitrogênio amoniacal dos esgotos afluente e efluente da ETE Juquitiba, após o início do lançamento do lodo da ETA no sistema de esgotos

Figura 5.30 - Diagrama "Box-plot" de NKT do esgoto bruto e tratado da ETE Juquitiba, sem o lançamento do lodo da ETA no sistema de esgotos

Figura 5.31 - Diagrama "Box-plot" de NKT do esgoto bruto e tratado da ETE Juquitiba, após o início do lançamento do lodo da ETA no sistema de esgotos

Figura 5.32 - Diagrama "Box-plot" de nitrogênio amoniacal do esgoto bruto e tratado da ETE Juquitiba, sem o lançamento do lodo da ETA no sistema de esgotos 
Figura 5.33 - Diagrama "Box-plot" de nitrogênio amoniacal do esgoto bruto e tratado da ETE Juquitiba, após o início do lançamento do lodo da ETA no sistema de esgotos.

Figura 5.34 - Séries temporais de fósforo total do esgoto afluente e efluente da ETE Juquitiba, após o início do lançamento do lodo da ETA no sistema de esgotos. 82

Figura 5.35 - Séries temporais de fósforo solúvel do esgoto afluente e efluente da ETE Juquitiba, após o início do lançamento do lodo da ETA no sistema de esgotos

Figura 5.36 - Diagrama "Box-plot" de fósforo total do esgoto bruto e tratado da ETE Juquitiba, sem o lançamento do lodo da ETA no sistema de esgotos

Figura 5.37 - Diagrama "Box-plot" de fósforo total do esgoto bruto e tratado da ETE Juquitiba, após o início do lançamento do lodo da ETA no sistema de esgotos 84 Figura 5.38 - Diagrama "Box-plot" de fósforo solúvel do esgoto bruto e tratado da ETE Juquitiba, sem o lançamento do lodo da ETA no sistema de esgotos 85

Figura 5.39 - Diagrama "Box-plot" de fósforo solúvel do esgoto bruto e tratado da ETE Juquitiba, após o início do lançamento do lodo da ETA no sistema de esgotos

Figura 5.40 - Séries temporais de oxigênio dissolvido do lodo dos reatores 1 e 2 da ETE Juquitiba, apo o início do lançamento do lodo da ETA no sistema de esgotos 87 Figura 5.41 - Séries temporais de alcalinidade dos esgotos afluente e tratado da ETE Juquitiba, após o início do lançamento do lodo da ETA no sistema de esgotos

Figura 5.42 - Diagrama "box-plot" da eficiência de remoção de $\mathrm{DBO}_{5,20}$ do esgoto bruto pela ETE Juquitiba, após o início do lançamento do lodo da ETA no sistema de esgotos.

Figura 5.43 - Diagrama "box-plot" da eficiência de remoção de DQO do esgoto bruto pela ETE Juquitiba, após o início do lançamento do lodo da ETA no sistema de esgotos. 89

Figura 5.44 - Diagrama "box-plot" da eficiência de remoção de NKT do esgoto bruto pela ETE Juquitiba, após o início do lançamento do lodo da ETA no sistema de esgotos.

Figura 5.45- Diagrama "box-plot" da eficiência de remoção de nitrogênio amoniacal do esgoto bruto pela ETE Juquitiba, após o início do lançamento do lodo da ETA no sistema de esgotos 
Figura 5.46 - Diagrama "box-plot" da eficiência de remoção de fósforo total do esgoto bruto pela ETE Juquitiba, após o início do lançamento do lodo da ETA no sistema de esgotos

Figura 5.47 - Diagrama "box-plot" da eficiência de remoção de fósforo solúvel do esgoto bruto pela ETE Juquitiba, após o início do lançamento do lodo da ETA no sistema de esgotos 


\section{LISTA DE TABELAS}

Tabela 3.1 - Correlação entre os parâmetros SST e turbidez da água bruta 13

Tabela 3.2 - Exemplo de valores típicos para parâmetros da caracterização de esgotos domésticos ( $\mathrm{mg} / \mathrm{L})$.

Tabela 3.3 - Exemplo de valores típicos para parâmetros da caracterização de esgotos domésticos ( $\mathrm{mg} / \mathrm{L})$.

Tabela 3.4 - Faixas de SVIST, \% de sólidos e densidade dos sólidos do lodo.

Tabela 4.1 - Ensaio de Jar-Test de aplicação de lodo da ETA Juquitiba no esgoto bruto afluente à ETE

Tabela 4.2 - Métodos analíticos e material utilizado na determinação de parâmetros (continua)

Tabela 4.2 - Métodos analíticos e material utilizado para determinação dos parâmetros (conclusão).

Tabela 5.1 -Dados de operação da ETA Juquitiba no período de 2 de agosto à 15 de novembro de 2006.

Tabela 5.2 - Resumo dos dados de volumes, vazões e concentrações de sólidos em suspensão total obtidos da ETA Juquitiba 53

Tabela 5.3 - Resumo das vazões de entrada de esgotos na ETE Juquitiba 54

Tabela 5.4 - Resumo da aplicação do lodo da ETA na ETE - Juquitiba .

Tabela 5.5 - Resultados médios dos parâmetros medidos nos resíduos da ETA Juquitiba 56

Tabela 5.6 - Vazão de esgoto afluente à ETE Juquitiba no período de 24 de maio à 26 de julho de 2006

Tabela 5.7 - Resultados dos parâmetros $\mathrm{DBO}_{5,20}$ e DQO do esgoto afluente e tratado da ETE Juquitiba, sem o lançamento do lodo da ETA no sistema de esgotos

Tabela 5.8 - Resultados dos parâmetros sólidos em suspensão totais, voláteis e fixos do esgoto afluente, tratado e do lodo dos reatores biológicos da ETE Juquitiba, sem o lançamento do lodo da ETA no sistema de esgotos

Tabela 5.9 - Resultados dos parâmetros NKT, nitrogênio amoniacal e nitrato do esgoto afluente e tratado da ETE Juquitiba, sem o lançamento do lodo da ETA no sistema de esgotos 
Tabela 5.10 - Resultados dos parâmetros fósforo total e solúvel do esgoto afluente e tratado da ETE Juquitiba, sem o lançamento do lodo da ETA no sistema de esgotos

Tabela 5.11 - Resultados dos parâmetros oxigênio dissolvido, temperatura, pH e alcalinidade do esgoto afluente, tratado e do lodo dos reatores biológicos da ETE Juquitiba, sem o lançamento do lodo da ETA no sistema de esgotos

Tabela 5.12 - Eficiências obtidas pela remoção dos parâmetros $\mathrm{DBO}_{5,20}$, DQO, NKT, nitrogênio amoniacal, fósforo total e solúvel do esgoto afluente da ETE Juquitiba, sem o lançamento do lodo da ETA no sistema de esgotos (continua).

Tabela 5.12 - Eficiências obtidas pela remoção dos parâmetros DBO5,20, DQO, NKT, nitrogênio amoniacal, fósforo total e solúvel do esgoto afluente da ETE Juquitiba, sem o lançamento do lodo da ETA no sistema de esgotos (conclusão)...69 Tabela 5.13 - Vazões de esgoto afluente à ETE Juquitiba nos períodos de 24 de maio à 26 de julho e 2 de agosto à 15 de novembro de 2006 .

Tabela 5.14 - Resultados dos parâmetros $\mathrm{DBO}_{5,20}$ e DQO do esgoto afluente e tratado da ETE Juquitiba, após o início do lançamento do lodo da ETA no sistema de esgotos.

Tabela 5.15 - Resultados dos parâmetros sólidos em suspensão totais, voláteis e fixos do esgoto afluente, tratado e do lodo dos reatores biológicos da ETE Juquitiba, após o início do lançamento do lodo da ETA no sistema de esgotos 76

Tabela 5.16 - Resultados dos parâmetros NKT e nitrogênio amoniacal do esgoto afluente e tratado da ETE Juquitiba, após o início do lançamento do lodo da ETA no sistema de esgotos

Tabela 5.17 - Resultados dos parâmetros fósforo total e solúvel do esgoto afluente e tratado da ETE Juquitiba, após o início do lançamento do lodo da ETA no sistema de esgotos.

Tabela 5.18 - Resultados dos parâmetros oxigênio dissolvido, temperatura, pH e alcalinidade dos esgotos afluente, tratado e do lodo dos reatores biológicos da ETE Juquitiba, após o início do lançamento do lodo da ETA no sistema de esgotos .86 Tabela 5.19 - Eficiência obtida pela remoção dos parâmetros DBO5,20, DQO, nitrogênio total e amoniacal, fósforo total e solúvel do esgoto afluente e tratado da ETE Juquitiba, após o início do lançamento do lodo da ETA no sistema de esgotos 


\section{LISTA DE QUADROS}

Quadro 3.1 - Caracterização semi-quantitativa por FRX, de amostras de lodo provenientes de diferentes ETA's pertencentes à bacia hidrográfica do Rio Ribeira de

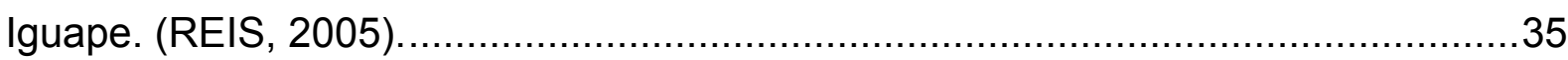

Quadro 5.1 - Resultados das análises da fase líquida do lodo da ETA, amostra 986 composta do lodo dos filtros e decantadores, pela técnica analítica ICP-OES/AA e dos compostos deste lodo pela técnica analítica Espectrometria de Fluorescência de

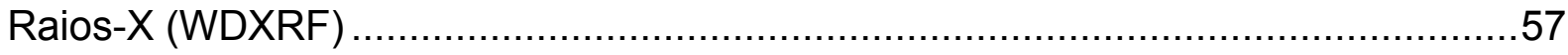




\section{SUMÁRIO}

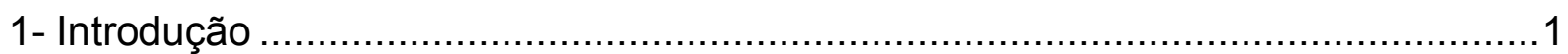

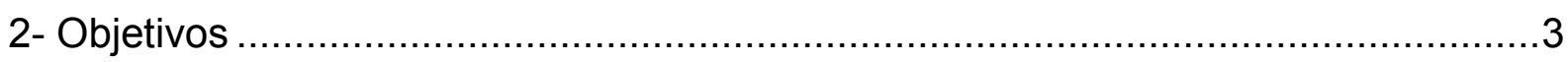

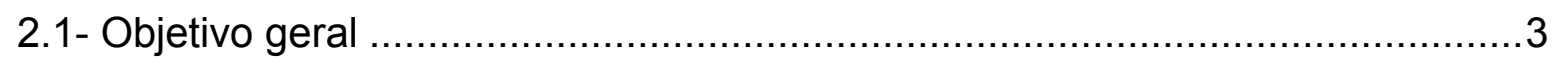

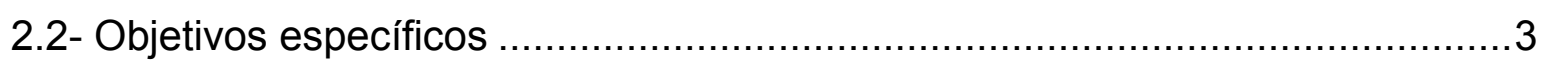

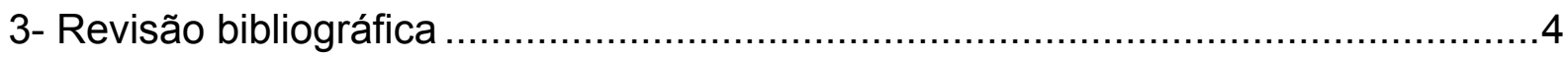

3.1- Estação de tratamento de água e a geração de resíduos ............................4

3.1.1- ETA Convencional..............................................................................

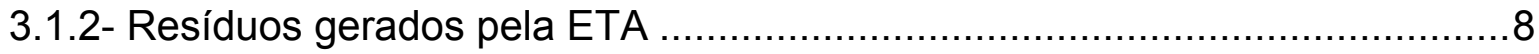

3.2- Estação de tratamento de esgotos pelo processo de lodo ativado em bateladas com aeração prolongada .................................................. 14

3.2.1- Considerações sobre lodo ativado ............................................... 14

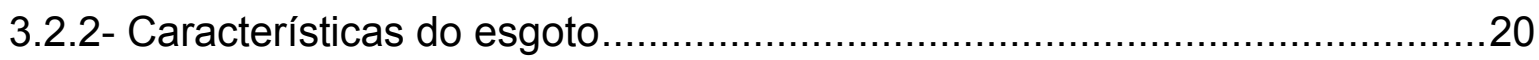

3.2.3- Microrganismos no processo de lodo ativado ...................................22

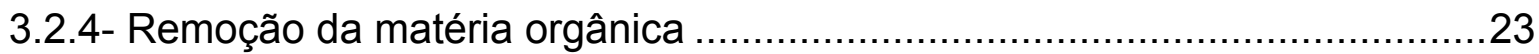

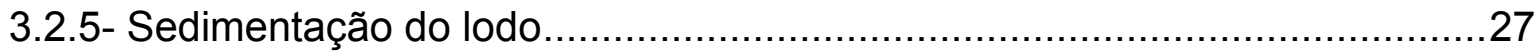

3.2.6- Tratamento e disposição final da fase sólida ...................................28

3.3- Lançamento do lodo de ETA na ETE ............................................. 31

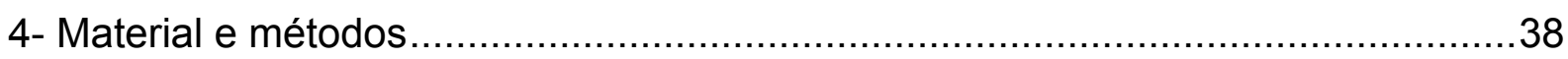

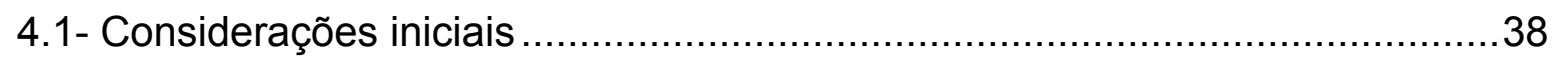

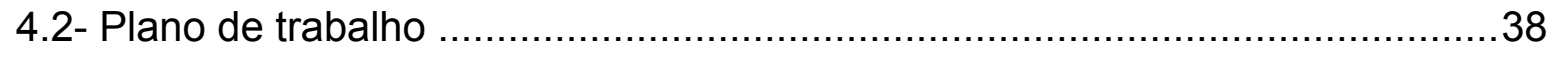

4.2.1- Caracterização do lodo da ETA ….................................................... 38

4.2.2- Caracterização dos esgotos bruto, tratado e do lodo da ETE ...................43

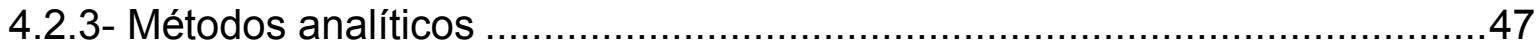

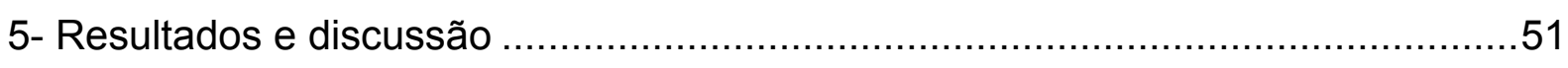

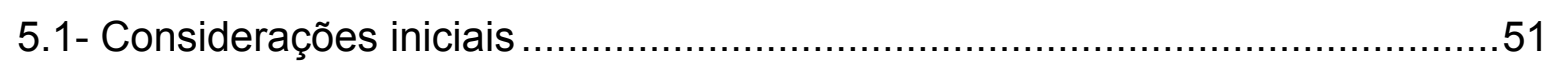

5.2- Caracterização do lodo gerado na estação de tratamento de água ...............51

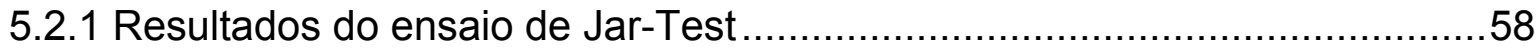

5.3- Caracterização dos esgotos bruto, tratado e do lodo do reator biológico da ETE, anteriormente ao início do lançamento do lodo da ETA no sistema de esgotos . 
5.4- Caracterização do esgoto bruto, tratado e do lodo do reator biológico da ETE, após o início do lançamento do lodo da ETA no sistema de esgotos....................72

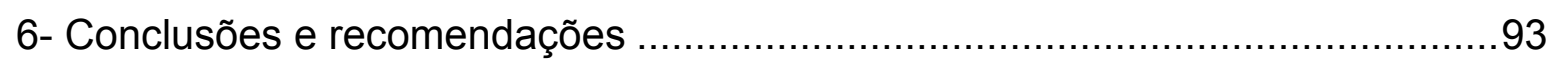

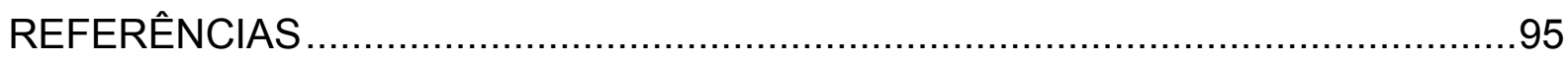

Anexo1 - Dados das caracterizações físico-quimicas .........................................99 


\section{1- Introdução}

O desenvolvimento sócio-econômico de um Estado está diretamente relacionado com a sua capacidade de explorar, utilizar e preservar seus recursos, sendo o resultado desta análise um fator determinante da qualidade de vida de sua população.

As concessionárias de saneamento tem como atividades a captação, tratamento, reservação e distribuição de água, a coleta, afastamento e tratamento dos esgotos, sendo estas atividades delicadas ao meio ambiente, pois como uma indústria, elas necessitam de matéria-prima, consomem energia e geram os produtos finais e os resíduos.

O tratamento e disposição de resíduos sólidos gerados durante o processo de tratamento de água tem recebido atenção no Brasil apenas nos últimos anos. Enquanto nos Estados Unidos e em certos países da Europa o problema do tratamento e disposição destes resíduos tem sido estudado extensivamente já na década de 70. Uma das grandes dificuldades na escolha de alternativas de engenharia que contemplem o tratamento de resíduos gerados em ETA's são a escassez de dados e bibliografia nacional a respeito do assunto, basicamente porque, no Brasil, poucas ETA's têm apresentado soluções que objetivam a minimização da quantidade de resíduos sólidos gerados, o seu tratamento e sua disposição final (FERREIRA FILHO e ALEM SOBRINHO, 1998).

As Estações de Tratamento de Água (ETA) para abastecimento público têm como principal função a remoção de impurezas constantes nas águas brutas e para isso empregam, na maioria das vezes, processos físico-químicos no seu tratamento, essas impurezas removidas, juntamente com resíduos dos produtos químicos aplicados, são denominados "lodo de ETA". Estes devem receber um tratamento e serem dispostos de maneira adequada. No Brasil é comum a prática do lançamento desse lodo nos corpos d'água próximos das ETA's, porém com o estreitamento da legislação as concessionárias de abastecimento vem sendo obrigadas investir no tratamento e disposição desse lodo.

Um método de disposição deste resíduo, que tem sido observado nos Estados Unidos, é o lançamento nas estações de tratamento de esgoto (ETE). Alguns estudos no Brasil sobre o lançamento do lodo de ETA nas ETE's mostraram 
as interferências sobre unidades predecessoras aos reatores biológicos como os estudos de Carvalho (2000) e Scalize (2003), aos digestores de lodo (como o descrito por Cinrta filho (2004). Quando se trata de tratamento de esgotos por lodo ativado convencional, e em processos biológicos anaeróbios, porém existe a necessidade de saber o impacto sobre o processo biológico de lodo ativado com aeração prolongada, ou seja, quando o lodo for despejado diretamente nos reatores biológicos.

No Município de Juquitiba - SP existe um sistema de água e esgotos operado pela SABESP, Companhia de Saneamento Básico do Estado de São Paulo, onde tem uma estação de tratamento de água, do tipo convencional, com coagulação, floculação, decantação e filtração, e que lança seus resíduos na galeria de águas pluviais, como em muitas outras estações de tratamento de água no Brasil. E tem uma estação de tratamento de esgotos por lodo ativado com reatores seqüenciais em bateladas e com aeração prolongada.

A disposição da planta dos equipamentos de saneamento, no município, é favorável para um trabalho conjunto entre a ETA e a ETE no tratamento das fases sólidas de ambas estações. A ETA encontra-se no início de uma rede coletora de esgotos que termina na estação elevatória de esgotos que abastece a ETE. Dessa maneira foi proposto o lançamento dos resíduos da estação de tratamento de água na rede coletora de esgotos, para o caminhamento até a ETE, onde existe um sistema de desaguamento e disposição dos resíduos sólidos gerados processo de tratamento de esgotos. 


\section{2- Objetivos}

\section{1- Objetivo geral}

Avaliar os efeitos do recebimento do lodo de ETA do Município de Juquitiba, que utiliza Sulfato de Alumínio como coagulante, pela ETE, também de Juquitiba, em escala real. Trata-se de uma ETA do tipo convencional, com floculação, decantação e filtração e uma ETE com dois reatores seqüenciais em bateladas que tratam os esgotos pelo processo de lodo ativado com aeração prolongada.

\section{2- Objetivos específicos}

a- Verificar o efeito do lodo da ETA sobre o equilíbrio do processo de lodo ativado, determinando a concentração de equilíbrio do lodo biológico da ETE afetado pelo acúmulo dos sólidos fixos provenientes do lodo da ETA,

b- Verificar se ocorrem efeitos adversos à nitrificação do esgoto,

c- Verificar se ocorrem efeitos positivos sobre a remoção de fósforo, tanto antes da chegada do lodo da ETA no reator biológico, ou seja, a captura de fósforo do esgoto bruto pelo lodo da ETA ao longo do caminhamento pela rede coletora, quanto no reator pelo processo biológico,

d- Verificar se o processo permanece estável, se é possível a manutenção de um equilíbrio consistente do sistema controlado pela idade do lodo,

e- Verificar se ocorrem alterações na produção e na desidratação do excesso de lodos ativados e

f- Verificar se a eficiência na remoção de DBO, DQO e sólidos em suspensão mantém-se estáveis e se não ocorrem episódios freqüentes de arraste de lodo com o efluente final. 


\section{3- Revisão bibliográfica}

\section{1- Estação de tratamento de água e a geração de resíduos}

A escolha da tecnologia de tratamento à ser utilizada depende das características biológicas, físicas e químicas (orgânicas, inorgânicas e radiológicas) de cada água, podendo exigir tratamento simples ou mais específicos, visando alcançar os padrões de potabilidade exigidos.

As características e quantidades dos resíduos gerados, por sua vez, irão depender do tipo de tratamento de água adotado, das características da água bruta, das dosagens e qualidades dos produtos químicos utilizados, das reações químicas ocorridas no processo e da forma de remoção e do tempo de retenção desses resíduos nas unidades de tratamento. Na Figura 1 tem-se a Estação de aptação de água bruta para ETA Juquitiba.

Existem diversos processos de tratamento de água como, por exemplo, tratamento sem coagulação química (filtração lenta), tratamento com coagulação química (filtração direta ou tratamento completo), arejamento, abrandamento (por troca iônica ou por dosagem de cal) e separação por membrana (microfiltração, ultrafiltração, nanofiltração e osmose reversa), cada um gerando resíduos de características distintas.

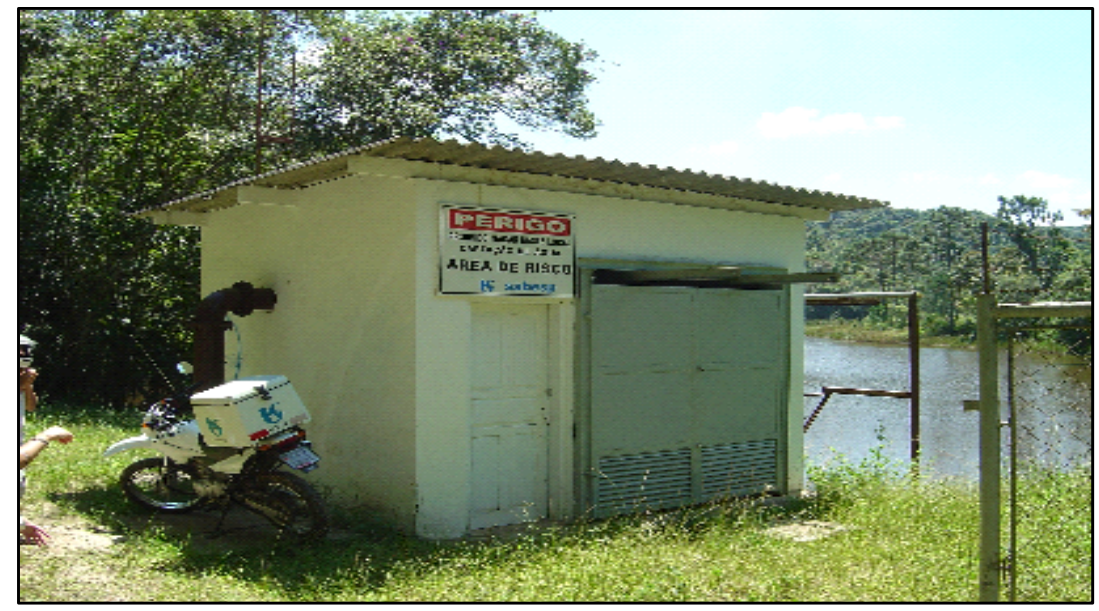

Figura 3.1 - Captação de água bruta superficial para a ETA Juquitiba -SP

No Brasil, a maioria das ETAs que tratam águas de mananciais superficiais utiliza o tratamento convencional de ciclo completo, com a aplicação de cloro para 
oxidar a matéria orgânica e alguns metais como ferro e manganês, facilitando sua remoção, e adição de cal ou soda para ajustar o pH para as fases seguintes do tratamento. Nos casos dos mananciais que possuem água com grande comprometimento de sua qualidade, o tratamento pode, ainda, ser complementado com o conjunto de outras técnicas, como adsorção em carvão ativado, ou apresentar algumas variações, como oxidação com permanganato de potássio, ou prédesinfecção com ozônio de forma a atender os requisitos de potabilidade.

\subsection{1- ETA Convencional}

A ETA do tipo convencional consiste nos seguintes processos unitários (DI BERNARDO, 1993):

- Coagulação: é um processo muito rápido realizado na ETA na unidade de mistura rápida, geralmente com a adição de sais de alumínio ou ferro ou de polímeros sintéticos. Resulta de dois fenômenos: químico, que consiste nas reações do coagulante com a água e na formação de espécies hidrolisadas com carga positiva, dependente da concentração de metal e pH final da mistura, e físico, que consiste no transporte das espécies hidrolisadas para que haja contato com as impurezas presentes na água. A coagulação depende fundamentalmente, das características da água e das impurezas presentes conhecidas através de parâmetros como $\mathrm{pH}$, alcalinidade, cor verdadeira, turbidez, temperatura, mobilidade eletroforética, força iônica, sólidos totais dissolvidos, tamanho e distribuição das partículas em estado coloidal e em suspensão, etc.

Os coagulantes mais utilizados nas ETAs são os sais de alumínio e ferro, como sulfato de alumínio $\left(\mathrm{Al}_{2}\left(\mathrm{SO}_{4}\right)_{3} \cdot 14 \mathrm{H}_{2} \mathrm{O}\right)$, cloreto férrico $\left(\mathrm{FeCl}_{3} \cdot 6 \mathrm{H}_{2} \mathrm{O}\right)$, sulfato férrico $\left(\mathrm{Fe}_{2}\left(\mathrm{SO}_{4}\right)_{3}\right)$, sulfato ferroso $\left(\mathrm{FeSO}_{4} .6 \mathrm{H}_{2} \mathrm{O}\right)$ e poli cloreto de alumínio. Como auxiliares de coagulação podem-se citar polímeros que podem ser catiônicos, aniônicos ou não iônicos.

- Floculação: ocorre em seguida da coagulação e consiste numa agitação da água de forma lenta para que ocorram choques entre as impurezas que se aglomeram formando partículas maiores denominadas flocos os quais podem ser removidas em etapas seguintes por sedimentação por flotação ou por filtração rápida. Com o aumento do tamanho dos agregados acontecem as forças de 
cisalhamento que podem romper os flocos. A agregação a e ruptura ocorrem simultaneamente, conduzindo a uma única distribuição de tamanho dos flocos.

Não deveria ocorrer no tanque de floculação a deposição dos flocos, seja por flotação, seja por sedimentação. A unidade floculadora noentanto acumula um pouco destes resíduos, pois sempre existe uma variação ou na vazão de água através da unidade ou na qualidade desta água, promovendo este acúmulo e sendo necessária a remoção periódica dos resíduos.

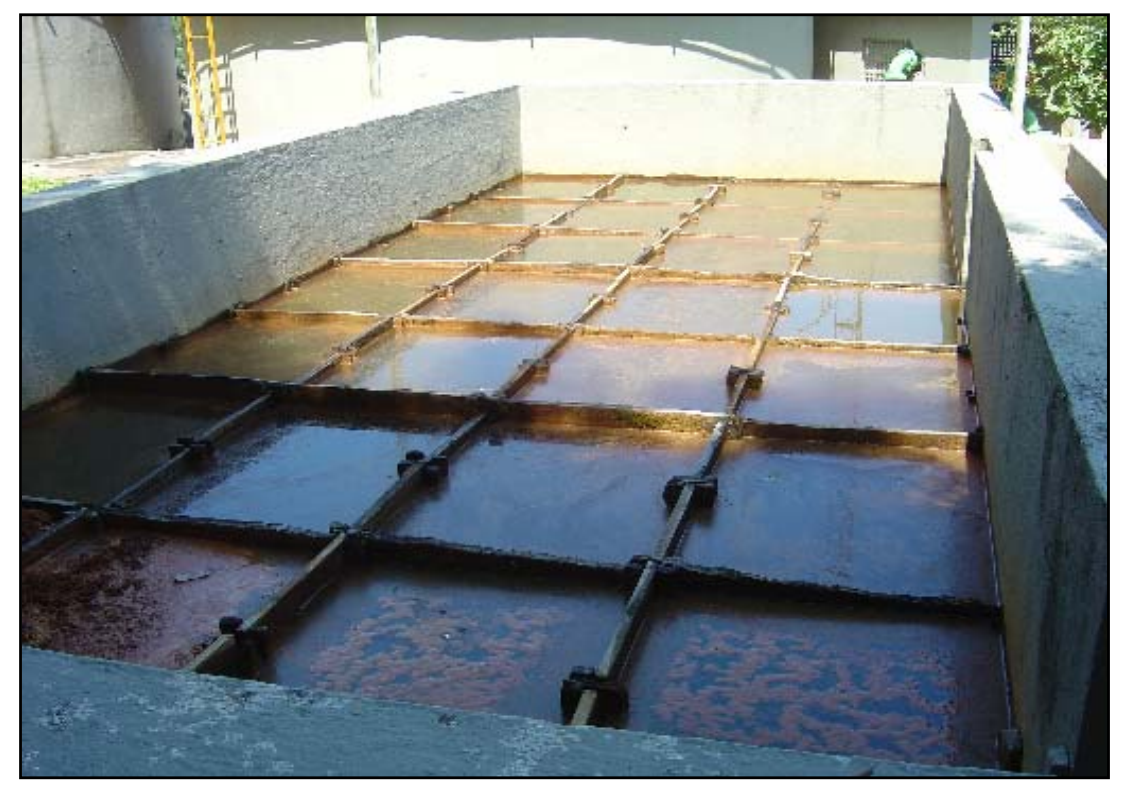

Figura 3.2 - Unidade de floculação da ETA Juquitiba - SP

- Sedimentação e flotação: a sedimentação que ocorre nos decantadores é o fenômeno físico em que as partículas suspensas formadas durante a floculação (flocos) apresentam movimento descendente em meio líquido de menor massa específica devido a ação da gravidade, indo depositar-se no fundo, formando o lodo. Já a flotação caracteriza-se pela ascensão das partículas suspensa pela aderência de bolhas de ar introduzidas no líquido, tornado-as de menor massa específica do que o meio onde se encontram. A sedimentação e a flotação das partículas suspensas propiciam a clarificação do meio líquido, ou seja, a separação das fases líquida e sólida. 


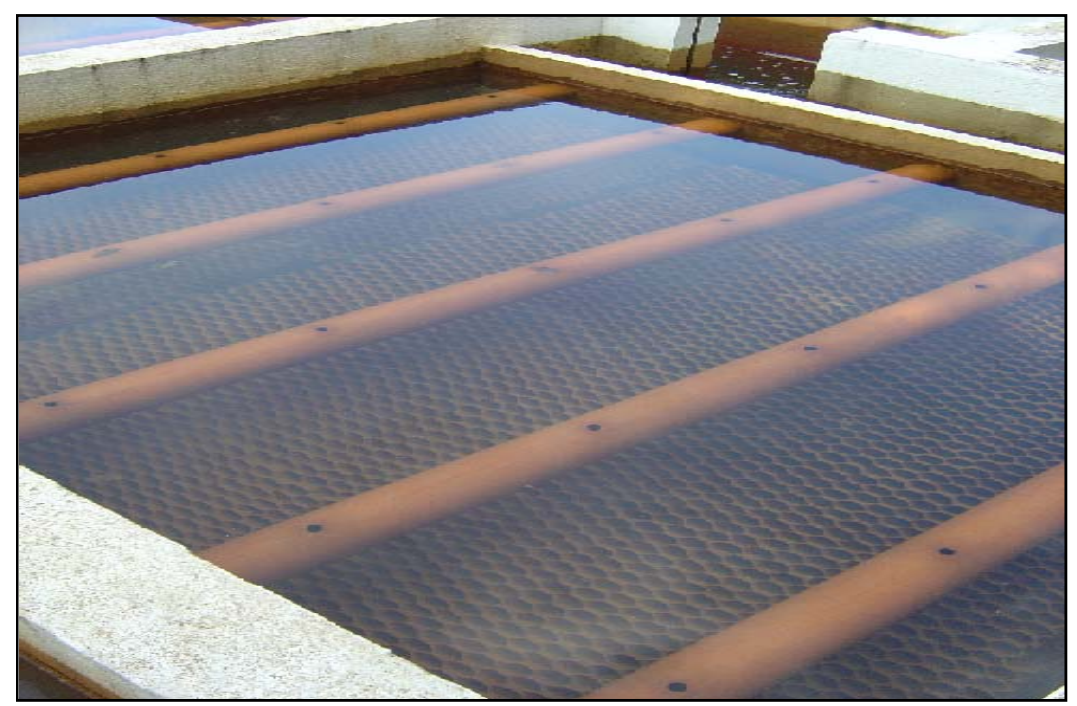

Figura 3.3 - Unidade de decantação da ETA Juquitiba - SP

- Filtração: pode ser lenta ou rápida. A filtração consiste na remoção das partículas suspensas e coloidais e dos microrganismos presentes na água que escoa através de um meio filtrante. O meio filtrante pode conter uma camada simples de areia ou uma camada dupla de areia e carvão antracito sobre uma camada suporte de pedregulho. Em geral, é o processo final de remoção de impurezas realizado numa ETA e, portanto, principal responsável pela produção de água com qualidade condizente com os padrões de potabilidade.

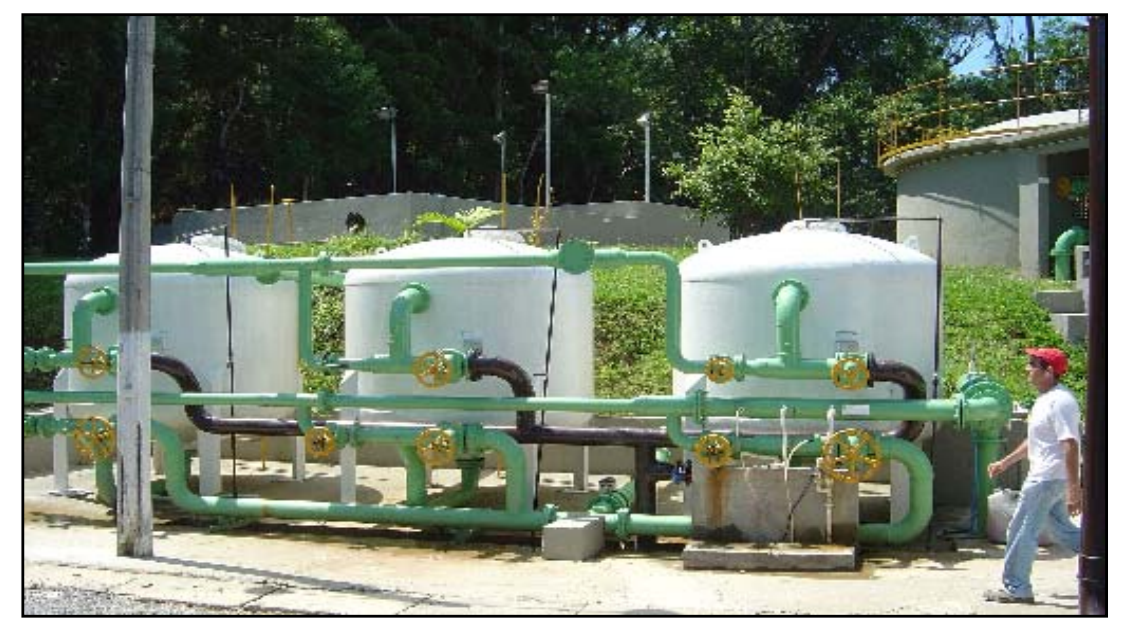

Figura 3.4 - Unidades de filtração da ETA Juquitiba - SP

- Desinfecção: é um processo que se usa um agente químico, ou não químico, que tem por objetivo a eliminação de microrganismos patogênicos presentes na água, como, bactérias, protozoários e vírus, além de algas, através da ocorrência de 
um ou mais mecanismos: destruição da estrutura celular, interferência no metabolismo com a inativação de enzimas e interferência na bio-síntese e no crescimento celular evitando a síntese de proteínas, ácidos nucléicos e co-enzimas.

A desinfecção é seletiva, isto é, não destrói todas as formas de vida e nem elimina todos organismos patogênicos. A destruição completa de toda a forma de vida é a esterilização. Dentre os agentes utilizados na desinfecção em geral têm-se os oxidantes cloro, bromo iodo ozônio, permanganato de potássio, peróxido de hidrogênio e os íons metálicos prata e cobre, e entre os agentes físicos destacam-se o calor e a radiação ultra-violeta.

- Para complementar o tratamento convencional pode ser adicionado outros produtos químicos à água, como cal, bicarbonato de sódio para o ajuste de $\mathrm{pH}$, flúor, em teores recomendados pela OMS, para a proteção da cárie dentária (DI BERNARDO, 1993).

\subsection{2- Resíduos gerados pela ETA}

A geração de resíduos em ETA's convencionais são: água de lavagem dos filtros, lodo dos decantadores e floculadores e rejeitos de limpeza dos tanques de preparo dos produtos químicos.

Cada uma dessas linhas geradoras apresenta características distintas em termos de teor de sólidos, variando significativamente em função da qualidade da água bruta a ser tratada e do tipo e dosagem de produtos químicos utilizados. Além disso deve-se considerar que um manancial sofre variações sazonais nas características da água, o que provoca variações nas quantidades de produtos químicos utilizados, influenciando por sua vez, na qualidade e quantidade de resíduos gerados.

Os resíduos produzidos nas ETA's convencionais caracterizam-se por possuírem grande umidade, geralmente maior que 95\%, estando sob a forma fluida. Em termos de volume, a maior quantidade de resíduos é proveniente da lavagem dos filtros e, em termos de massa de sólidos, as maiores quantidades são geradas nos decantadores. A sistemática de gestão de ETA's é bastante parecidas em todo o Brasil e particularmente em São Paulo, sendo geradas algumas toneladas de lodo de ETA diariamente que são dispostos no meio ambiente. 
O lançamento dos resíduos de ETA nos curso d'água pode introduzir toxicidade dos organismos aquáticos e aumentar a degradação da qualidade das águas e sedimentos destes ambientes pois além de conter metais, como alumínio, ferro, manganês e outros, apresentam altas concentrações de sólidos, turbidez e DQO, fatores estes que podem causar a formação de bancos de lodo, assoreamento, alterações de cor, além de distúrbios na composição química e biológica do corpo receptor (CORDEIRO, 1993).

Água de lavagem de filtros é produzida em um grande volume e contém um baixo teor de sólidos, variando de 0,01 à 0,1\%, dependendo da eficiência dos filtros. Os filtros são lavados periodicamente e a fração de água utilizada para as lavagens é da ordem de 1 à $5 \%$ da água total tratada (REALI,1999).

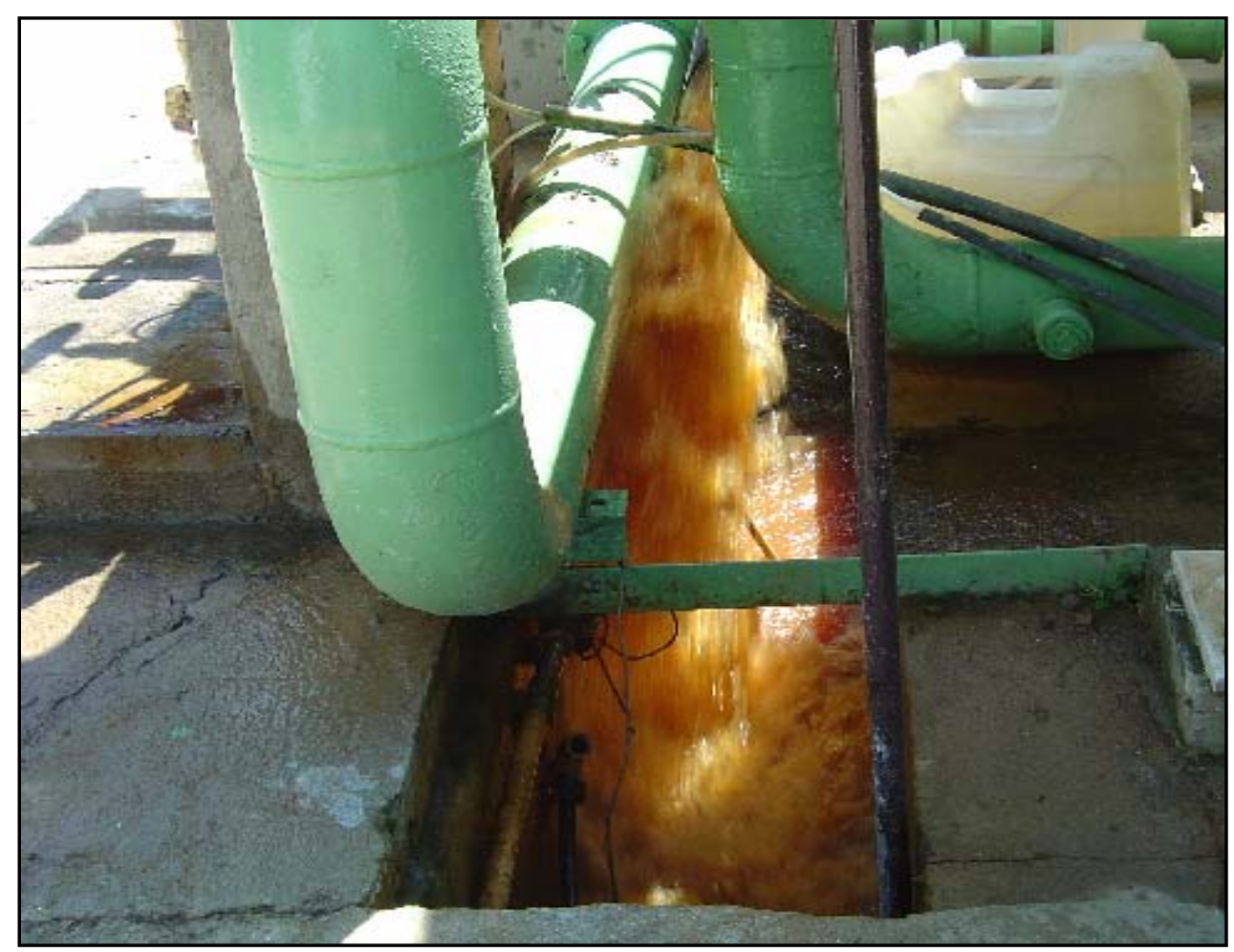

Figura 3.5 - Água de retro-lavagem dos filtros da ETA Juquitiba - SP

As características dos resíduos dependem do método e da periodicidade das lavagens e a sua composição qualitativa assemelha-se à do lodo do decantadores.

A matéria sólida das águas de lavagem é formada por flocos remanescentes da decantação, podendo conter hidróxidos de alumínio e ferro, óxidos de ferro manganês e magnésio, carbonatos de cálcio e ferro, sílica e partícula finas de argila, além disso, matéria orgânica pode estar presente na forma de algas, plânctons, etc. 
O lodo dos decantadores é produzido devido à acumulação do produto da coagulação e da floculação pela separação dos sólidos do líquido. Em decantadores convencionais, o processo de remoção do lodo pode ser feito periodicamente ou de forma contínua. Quando não é utilizada a forma contínua, a periodicidade gira em torno de 15 dias à 2 ou 3 meses, sendo então feita a remoção em forma de bateladas. Esta situação dificulta o gerenciamento dos resíduos. No caso de remoção contínua que se dá mecânica ou hidraulicamente, é possível obter um maior controle do sistema de tratamento do resíduo evitando também a ocorrência de condições anaeróbias no lodo que ficaria depositado no fundo do decantador.

As características dos lodos gerados nos decantadores com sistemas de remoção em bateladas e de forma contínua são bastante distintas. Lodos descarregados continuamente apresentam teores de sólidos variando temporalmente da ordem de 0,1 à $2,5 \%$. Os removidos em bateladas podem alcançar até $5 \%$ de teor de sólidos (REALI, 1999).

Os lodos gerados nos decantadores de uma ETA que utiliza sais metálicos (alumínio e ferro), contêm, essencialmente, as substancias em suspensão na água bruta, como siltes, argilas e substâncias orgânicas, os hidróxidos metálicos, outros precipitados provenientes da coagulação e ouros aditivos usados no tratamento tais como polieletrólitos, cal e carvão ativado. Assim como a variação da água bruta devido a sazonalidade o lodo apresenta um aumento da matéria orgânica e decréscimo do conteúdo mineral no período chuvoso e o inverso na estiagem.

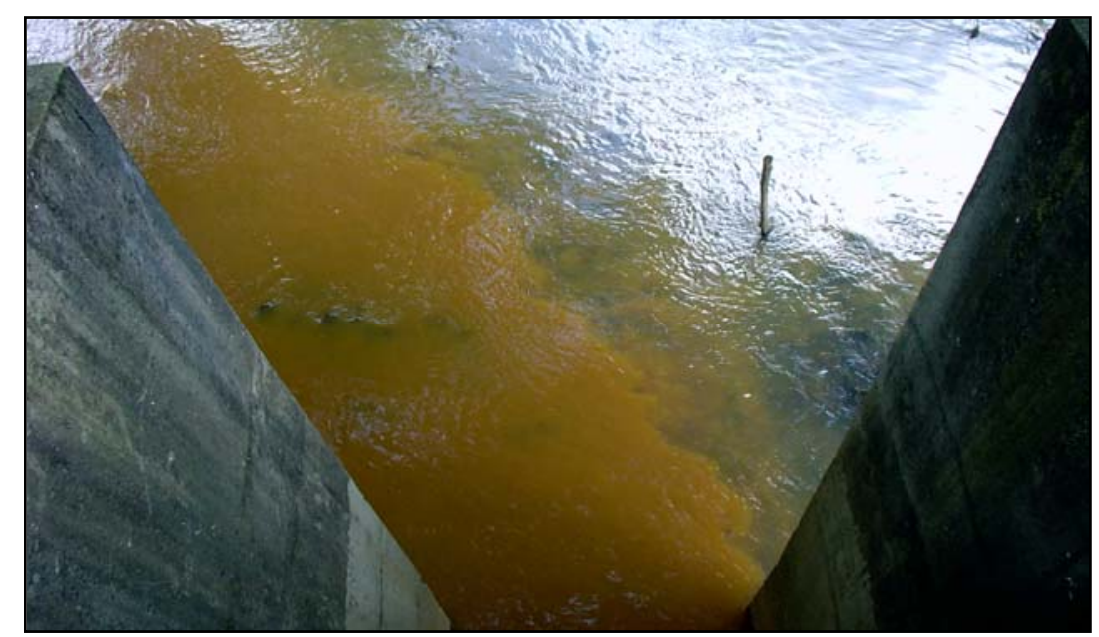

Figura 3.6 - Descarga de lodo de ETA no corpo d'água 
Normalmente os lodos são biologicamente inertes, com baixo teor de matéria orgânica biodegradável, porém podem conter também bactérias, vírus e algas removidos no processo de sedimentação.

A crescente necessidade de processar os lodos de ETA para a sua disposição final tem intensificado as investigações em relação as suas características físicas e químicas, características estas que afetam significativamente a habilidade de manusear, adensar, desidratar e transportar os lodos, bem como afetam as próprias opções de uso e disposição.

Os principais parâmetros físico-químicos utilizados para a caracterização dos lodos de ETA's são: tipo e concentração de sólidos (totais, voláteis, suspensos totais e suspensos voláteis), granulometria, densidade, resistência específica, pH, DBO, DQO, concentração dos principais íons metálicos de interesse (por exemplo: alumínio, ferro, manganês, cádmio, cobre, cromo, chumbo, mercúrio, níquel, zinco, etc.), concentração de fósforo total, nitrogênio total, além de índices bacteriológicos e biológicos de interesse sanitário, como coliformes totais e fecais.

A maior parte dos metais pesados presentes em lodos de ETA's são de impurezas contidas nos coagulantes. Desse modo, suas concentrações podem ser limitadas através do controle efetivo da qualidade dos coagulantes e de outros produtos químicos utilizados no tratamento de água (JANUARIO, 2005).

Produção de lodos: a quantidade de resíduos gerados em ETA's depende da qualidade da água bruta, do tipo e dosagem dos produtos químicos e do desempenho do processo de tratamento. Sua quantificação é de suma importância para o dimensionamento e operação tanto dos sistemas de adensamento e desidratação quanto das formas e uso e disposição.

A determinação da produção de lodo em sistemas de tratamento de água pode ser estimada com base em dois parâmetros: (1) a massa de sólidos secos presentes no lodo resultante e (2) o volume de água descartada que atua como veículo da massa de sólidos (REALI, 1999). 


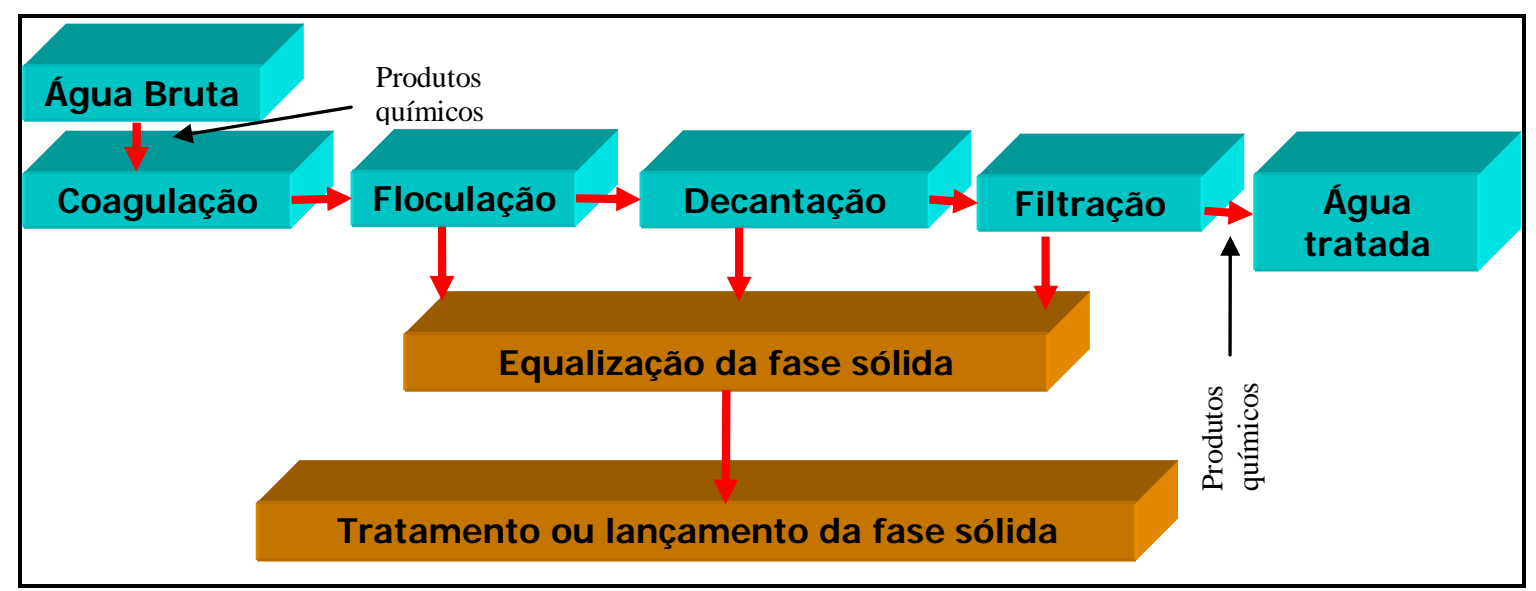

Figura 3.7 - Fluxograma simplificado das fases líquida e sólida de uma ETA

A quantidade de lodo gerada pode ser estimada "in loco", pela determinação de sólidos provenientes das descargas dos decantadores e de suas vazões, ou ainda ser calculada matematicamente utilizando fórmulas teórica. Em ambos os casos são convenientes o levantamento de dados da qualidade da água bruta (sólidos suspensos totais) e do consumo de produtos químicos durante um período de no mínimo um ano (FERREIRA FILHO e ALEM SOBRINHO, 1998).

Muitos pesquisadores desenvolveram formulações matemáticas distintas para fazer a estimativa da produção de sólidos secos. Para facilitar a utilização das fórmulas substituiu-se o parâmetro sólidos suspensos por turbidez, como demonstrado na Tabela 3.1, uma vez que os dados sólidos suspensos não estão normalmente disponíveis nas estações de tratamento de água.

Assumindo que o residual de alumínio e ferro sejam desprezíveis na água tratada, a produção de lodo para ambos coagulantes pode ser estimada através das seguintes expressões:

$$
\begin{aligned}
& P_{L}=Q \cdot\left(4,89 \cdot D_{A l}+S S+C A P+O A\right) \cdot 10^{-3} \\
& P_{L}=Q \cdot\left(2,88 \cdot D_{F e}+S S+C A P+O A\right) \cdot 10^{-3}
\end{aligned}
$$

onde:

$\mathrm{P}_{\mathrm{L}}=$ produção de lodo seco em $\mathrm{kg} / \mathrm{dia}$,

$\mathrm{Q}=$ vazão de água bruta em $\mathrm{m}^{3} / \mathrm{dia}$,

$D_{A l}=$ dosagem de sais de alumínio, expresso como Al em mg/L,

$D_{\mathrm{Fe}}=$ dosagem de sais de ferro, expresso como Fe em mg/L, 
SS = concentração de sólidos em suspensão totais na água bruta em $\mathrm{mg} / \mathrm{L}$, $\mathrm{CAP}=$ concentração de carvão ativado em pó em $\mathrm{mg} / \mathrm{L}$, $\mathrm{OA}=$ outros aditivos em $\mathrm{mg} / \mathrm{l}$ (sílica ativada, polímeros, etc...).

Os coeficientes 4,89 e 2,88 presentes nas Equações (1) e (2) foram obtidos partindo-se do pressuposto de que todo o alumínio ou ferro adicionado na água bruta precipita-se como hidróxido metálico e que a cada molécula de $\mathrm{Fe}(\mathrm{OH})_{3}$ ou $\mathrm{Al}(\mathrm{OH})_{3}$ é incorporado cerca de três a quatro moléculas de água (FERREIRA FILHO e ALEM SOBRINHO, 1998).

Tabela 3.1 - Correlação entre os parâmetros SST e turbidez da água bruta

\begin{tabular}{cc}
\hline \hline Turbidez (UNT) & SST (mg/l) \\
\hline 5 & 5 \\
30 & 30 \\
\hline \hline
\end{tabular}

Fonte: Ferreira Filho, 2005

Este material produzido deve receber um tratamento e uma disposição final. Pode ser descartado definitivamente, por exemplo, em aterros ou podem ser utilizados como matéria prima para outras atividades, como as de produção de materiais cerâmicos.

Como a maior parte das ETA's no Brasil não possui nenhum tipo de tratamento da fase sólida e, como para atender as legislações vigentes necessita de soluções, uma das opções, que normalmente é a mais econômica e rápida no que diz respeito à implantação, é o lançamento na rede coletora de esgotos para caminhamento até a ETE, uma vez que estas têm como tradição o tratamento também da fase sólida. 


\section{2- Estação de tratamento de esgotos pelo processo de lodo ativado em bateladas com aeração prolongada}

\subsection{1- Considerações sobre lodo ativado}

A principal meta da Engenharia Sanitária é a proteção da saúde pública. No que tange o tratamento dos esgotos é necessário o conhecimento dos seus constituintes e o impacto que eles causam quando dispersos no meio ambiente (METCALF \& EDDY, 2003).

O processo de lodo ativado é atualmente muito utilizado no tratamento de efluentes municipais e industriais. Os primeiros dados do processo de lodo ativado datam de meados de 1880 num trabalho do Dr. Angus Smith, quando investigava a aeração dos esgotos em tanques acelerando a oxidação da matéria orgânica. A aeração dos esgotos foi estudada subseqüentemente por uma série de pesquisadores e, em 1910, Black e Phelps relataram que uma considerável redução no apodrecimento do esgoto poderia ser obtida com a introdução de ar no tanque desse material. Após alguns estudos nos Estados Unidos e na Inglaterra, Ardern e Lockett perceberam que o lodo aerado teve um papel importante nos resultados obtidos devido a remoção de matéria orgânica do líquido, como mostrado no seu artigo de 3 de maio de 1914 (Ardern and Lockett, 1914). O processo foi denominado de lodo ativado por Adern e Lockett devido a capacidade de uma massa de lodo aerada estabilizar o material orgânico dos esgotos (METCALF \& EDDY, 1930, apud METCAF \&EDDY, 2003).

Por definição o processo de lodo ativado consiste dos três componentes básicos seguintes: 1) um reator no qual os microrganismos responsáveis pelo tratamento são mantidos em suspensão e aerados; 2) a separação dos sólidos do líquido se dá num tanque de sedimentação; e 3) um sistema de reciclo de sólidos para recuperar os sólidos removidos pela unidade de separação de sólidos-líquido e seu retorno ao reator. Uma importante característica do processo de lodo ativado é a formação de sólidos floculentos sedimentáveis, que podem ser removidos por ação da gravidade em tanques de sedimentação (METCALF \& EDDY, 2003).

Como os microrganismos são mantidos no sistema através de seu reciclo por mais tempo do que o líquido, foi determinada uma unidade de medida que permite 
estabelecer a relação entre a quantidade de esgotos que deve ser tratada e a quantidade de microrganismo necessária para tal, a "idade do lodo".

A idade do lodo tem como definição a quantidade de lodo existente dentro de um reator biológico, em $\mathrm{mg} / \mathrm{L}$, e a quantidade de lodo produzida diariamente devido o aporte de material orgânico no reator, em mg/L.dia, ou ainda, a quantidade de lodo existente no reator, em $\mathrm{mg} / \mathrm{L}$, dividido pela quantidade de lodo retirada diariamente do sistema, em mg/L.dia. A unidade de idade do lodo é então "dias". O lodo retirado do reator para o controle da idade do lodo é chamado de "lodo de excesso", este é o resíduo da estação de tratamento de esgotos por lodo ativado e deve sofrer tratamento e disposição adequado.

Existem algumas variações no processo de lodo ativado devido à diferentes aspectos, como apresentado a seguir:

a- devido ao tempo de permanência do lodo biológico (idade do lodo) no sistema: (1) aeração modificada (inferior a 3 dias); (2) convencional (3 à 10 dias) e (3) aeração prolongada (17 à 30 dias),

b- devido ao tipo de fluxo do afluente do reator biológico: (1) fluxo contínuo e (2) fluxo intermitente (em bateladas) e

c- devido às características qualitativas do afluente do reator biológico: (1) esgoto bruto; (2) efluente de decantador primário; (3) efluente de reator anaeróbio e (4) efluente de outro processo de tratamento de esgotos.

Os sistemas mais comumente utilizados são o sistema de lodos ativado convencional para tratar efluentes de decantador primário e o de lodo ativado com aeração prolongada para tratar esgoto bruto. Alguns fatores como a qualidade e a quantidade do esgoto bruto são determinantes na escolha do sistema a ser utilizado.

Estão apresentados nas Figuras 3.8 e 3.9, esquematicamente, os sistemas de lodo ativado com abastecimento contínuo de esgoto bruto e de lodo ativado com abastecimento em forma de bateladas de esgoto bruto no reator biológico, respectivamente.

Para o sistema de fluxo contínuo nota-se que deve existir dois tanques separados para que as etapas de reação e decantação possam ocorrer ininterruptamente. 


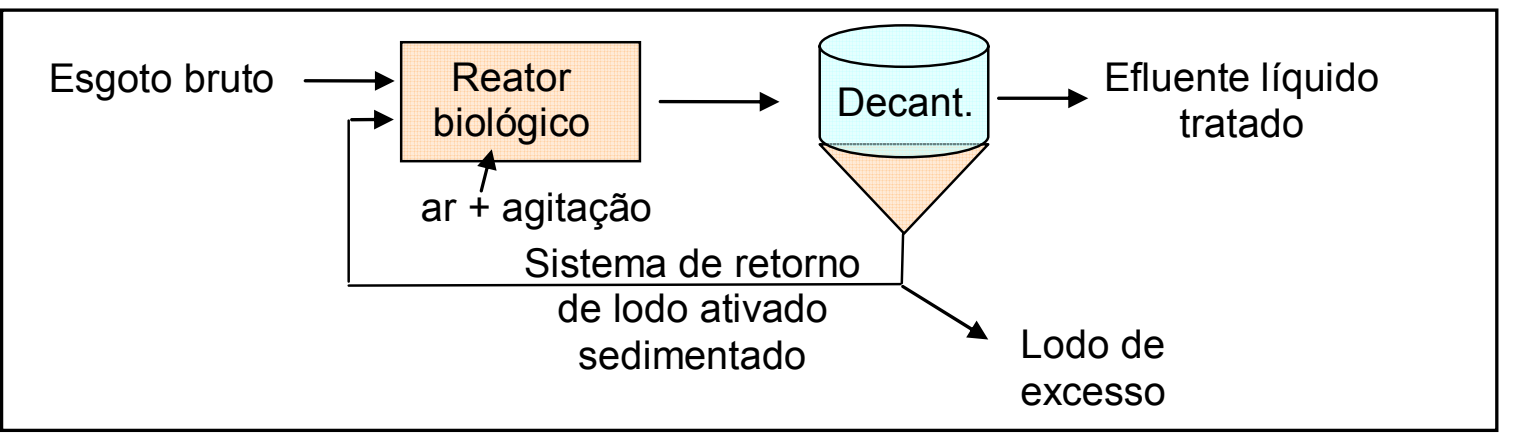

Figura 3.8 - Esquema simplificado do sistema de lodo ativado de fluxo contínuo

Já no sistema de fluxo intermitente dos esgotos no reator biológico, por batelada, as atividades de reação e decantação ocorrem num único reator, sendo necessário para isso um maior controle operacional.

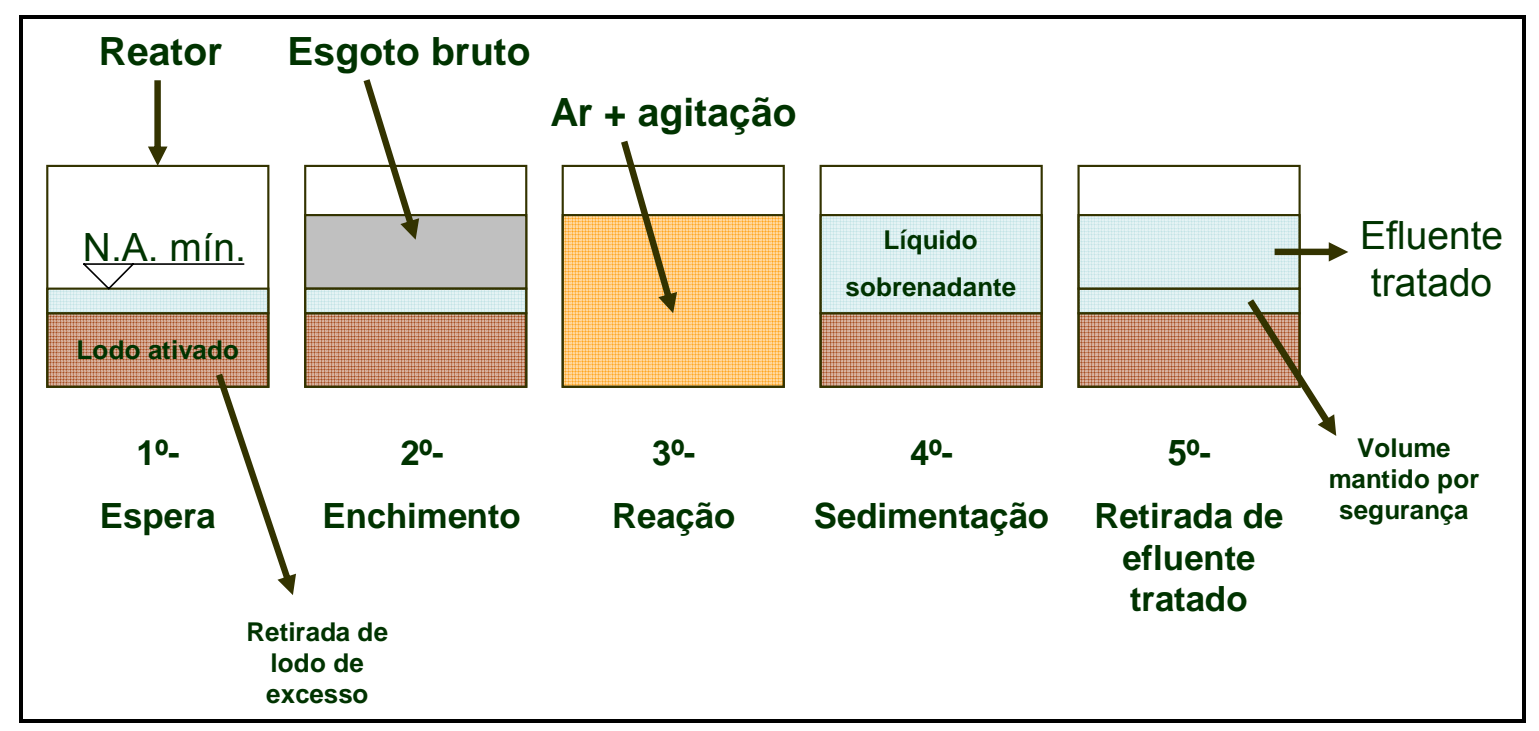

Figura 3.9 - Esquema simplificado do sistema de lodos ativados em bateladas

Um grande número de conFigurações de processo de lodo ativado tem sido desenvolvido com suas devidas finalidades, como: (1) atendimento de diferentes requisitos de tratamento; (2) desenvolvimento e uso de tecnologias de controle e automação diferentes; (3) aumento do conhecimento do processo biológico e seus fundamentos e (4) a constante necessidade de redução de custos de implantação e operação.

No caso de lodo ativado com aeração prolongada, a biomassa é mantida no sistema entre 17 e 30 dias (daí o nome aeração prolongada). Naturalmente há uma maior quantidade de microorganismos no reator em relação ao sistema convencional (idade do lodo de 3 à 10 dias). O volume do reator biológico também é maior num 
sistema com aeração prolongada se comparado com um sistema de fluxo contínuo que tratam a mesma quantidade de afluentes. Por isso para uma mesma quantidade de matéria orgânica (esgoto) aplicada diariamente no sistema com aeração prolongada apresenta uma menor relação entre a matéria orgânica e o volume do reator, ou por unidade de biomassa do reator, denominada relação alimento / microrganismo.

Em decorrência da menor relação alimento / microrganismo, as bactérias, para sobreviver passam a utilizar de maneira mais intensa nos seus processos metabólicos a própria matéria orgânica biodegradável componente das suas células. Esta matéria orgânica celular é convertida em gás carbônico, água e resíduo inerte. Por se tratar do consumo de material intra-celular, à esta atividade denomina-se respiração endógena. Isto corresponde a uma estabilização da biomassa ocorrendo no próprio tanque de aeração.

Enquanto no sistema com aeração prolongada a estabilização da biomassa é feita conjuntamente com o tratamento da fase líquida de maneira aerada no próprio reator biológico, no sistema convencional a estabilização do lodo é feita em tanques separados, chamado de tratamento da fase sólida, normalmente utilizando-se de ambientes anaeróbios. Para a estabilização da biomassa de maneira aerada existe um consumo de oxigênio adicional e isto pode ser considerado significativo para a decisão da escolha do tipo de processo.

Já que não há a necessidade de estabilização do lodo biológico de excesso no sistema com aeração prolongada, procura-se também não gerar nenhuma outra forma de lodo que venha requerer posterior estabilização, por exemplo o lodo de decantador primário. Com isso obtém-se uma grande simplificação no fluxograma do processo, não há decantadores primários nem unidades de digestão de lodo. $\mathrm{A}$ conseqüência desta simplificação do sistema é o gasto de energia para aeração do lodo que é estabilizado no tanque de aeração. Por outro lado a reduzida disponibilidade de alimento e a sua praticamente total assimilação fazem com que a variante do processo de lodo ativado com aeração prolongada seja a mais eficiente na remoção de DBO (VON SPERLING, 2002).

É muito usual a utilização de lodo ativado com aeração prolongada para reatores em bateladas. Mesmo que a chegada de esgoto bruto se dê de forma contínua numa estação de tratamento é possível com dois ou mais reatores utilizar esta alternativa, desde que seja economicamente viável. Todos sistemas de lodo 
ativado por bateladas têm cinco passos em comum, os quais são conduzidos em seqüência como listado a seguir: (1) enchimento; (2) reação; (3) sedimentação; (4) retirada de efluente tratado e (5) espera ou ajuste. Cada um desses passos acontece em um único reator e estão ilustrados na Figura 3.9.

A etapa de enchimento é aonde acontece a adição de matéria orgânica, ou substrato (esgoto bruto por exemplo) ao reator. Esta adição pode ser controlada por volume ou por tempo de enchimento. Se o controle se der por volume a etapa de enchimento permite que o nível do líquido no reator seja elevado a sua capacidade máxima em todas as bateladas, se o controle se der por tempo é necessário conhecer a variação de vazão do afluente do reator ao longo do dia para calcular o tempo de enchimento em função dos volumes desejados. Um avanço no sistema de bateladas com controle de enchimento por tempo é a possibilidade de alterar as condições do reator durante esta etapa para alcançar metas de tratamento, por exemplo: enchimento com aeração, enchimento com mistura lenta promovendo condição anóxica, entre outras.

$\mathrm{Na}$ etapa de reação a biomassa é ativada com a introdução de oxigênio e agitação e consome a matéria orgânica em condições controladas como o próprio tempo de reação, a quantidade de oxigênio dissolvido, etc.

$\mathrm{Na}$ etapa de sedimentação os sólidos são separados do líquido sob condições estanques, ou seja, sem a interferência de fluxo de entrada e de saída de líquidos no reator. A etapa de sedimentação é controlada por tempo e é fixada de modo que a manta de lodo sedimente o suficiente para promover a retirada do sobrenadante com segurança.

A retirada de efluente tratado é feita através de calhas vertedoras flutuantes ou mecanismos que permitam sempre a retirada do sobrenadante pela sua superfície.

A etapa de espera é a que permite que as variações de vazões ao longo do dia não prejudiquem o ciclo de operação quando se trata de dois ou mais reatores, pois na etapa anterior, a de retirada de efluente tratado, o volume removido do reator é sempre o mesmo daquele que entrou na etapa de enchimento. Normalmente fixase a soma dos tempos das etapas de retirada de efluente tratado e de espera, assim quanto maior um dos dois tempos, menor o outro e vice-versa.

O sistema por bateladas com apenas um reator é utilizado apenas por alguns segmentos de indústrias que geram seus efluentes com programação, ou por 
pequenas comunidades que têm suas vazões noturnas tendendo a zero e vazões diurnas pequenas, sendo possível armazenar os afluentes em pequenos tanques de equalização seguidamente promover tratamento.

Algumas vantagens do sistema de lodos ativados por bateladas são: (1) os reatores são tanques de equalização do esgoto bruto com a biomassa durante a etapa de enchimento, permitindo assim, uma maior tolerância a grandes variações do fluxo e de cargas de choque minimizando prejuízos do efluente final; (2) como a retirada de efluente final é periódica é possível, dentro de alguns limites, conter o efluente até atingir alguns requisitos de tratamento específicos; (3) durante o início de plano quando as vazões ainda são pequenas é possível usar uma fração do tanque de modo a manter as características de operação desejada; (4) os sólidos do licor misto não podem ser lavados do sistema devido o surgimento de grandes cargas hidráulicas, uma vez que podem ser mantidos no sistema o tempo desejado; (5) não necessita de sistema de retorno de lodo; (6) a separação sólidos-líquido acontece em condições estanques; (7) a proliferação de microrganismos filamentosos pode ser controlada pela variação da estratégia de operação durante o enchimento; (8) este sistema pode ser operado estrategicamente para atingir a nitrificação e a desnitrificação e ainda, a remoção de fósforo com ou sem a adição de produtos químicos e (9) tem sido relatado que o RNA contido nos microrganismos de sistemas em bateladas são 3 a 4 vezes maiores que os encontrados nos sistemas do fluxo contínuo. Visto que a taxa de crescimento dos microrganismos é conhecida e depende do RNA contido nas células, notou-se que culturas de microrganismos dos sistemas por bateladas processam uma quantidade maior de substrato promovendo assim um crescimento celular que as culturas dos microrganismos de sistemas de fluxo contínuo (EPA, 1986).

Existem também algumas desvantagens desse tipo de sistema como: (1) um alto nível de sofisticação requerido para seu controle como a automação, válvulas pneumáticas ou eletrônicas, etc; (2) uma operação mais especializada devido os equipamentos instalados; (3) um desgaste excessivo do sistema de aeração devido a ação de liga/desliga ao longo dos ciclos. 


\subsection{2- Características do esgoto}

Os esgotos oriundos de uma cidade e que contribuem à estação de tratamento de esgotos são basicamente originados de três fontes distintas: (1) esgotos domésticos (incluindo residências, instituições e comércio), (2) águas de infiltração e (3) despejos industriais.

Os esgotos domésticos contêm aproximadamente $99,9 \%$ de água, a fração restante inclui sólidos orgânicos e inorgânicos, suspensos e dissolvidos, bem como microrganismos. Portanto é devido a essa fração de $0,1 \%$ que há a necessidade de se tratar os esgotos.

A característica dos esgotos é função dos usos à qual a água foi submetida. Esses usos e a forma com que são exercidos variam com o clima, a situação social e econômica e hábitos da população (VON SPERLING, 1996).

Tabela 3.2 - Exemplo de valores típicos para parâmetros da caracterização de esgotos domésticos ( $\mathrm{mg} / \mathrm{L})$.

\begin{tabular}{cccc}
\hline Parâmetro & $\begin{array}{c}\text { Esgotos } \\
\text { forte }\end{array}$ & $\begin{array}{c}\text { Esgoto } \\
\text { Médio }\end{array}$ & $\begin{array}{c}\text { Esgoto } \\
\text { Fraco }\end{array}$ \\
\hline $\mathrm{DBO}_{5,20}$ & 400 & 200 & 100 \\
$\mathrm{DQO}$ & 800 & 400 & 200 \\
$\mathrm{SST}$ & 360 & 230 & 120 \\
$\mathrm{SSV}$ & 280 & 175 & 90 \\
$\mathrm{NKT}$ & 85 & 40 & 20 \\
$\mathrm{~N}^{-\mathrm{NH}_{4}}-$ & 50 & 20 & 10 \\
$\mathrm{~N}^{-}$ & 0,40 & 0,20 & 0,10 \\
Fósforo total $^{-}$ & 20 & 10 & 5 \\
Fósforo solúvel & 13 & 6 & 3 \\
\hline
\end{tabular}

Fonte: Adaptado de JORDÃO e PESSOA, 2005.

As características físicas dos esgotos podem ser interpretadas pela obtenção das grandezas correspondentes as determinações de materiais sólidos, temperatura, odor, cor e turbidez. As características químicas podem ser classificadas em dois grandes grupos: o grupo da matéria orgânica e o grupo da matéria inorgânica. $O$ grupo de material orgânico nos esgotos é principalmente constituído por: proteínas (40 à $60 \%$ ), carboidratos (25 à 50\%), gordura e óleos (10\%) e uréia, surfactantes, fenóis, pesticidas, etc. $O$ grupo de material inorgânico nos esgotos é formado 
principalmente por areia e substâncias minerais dissolvidas (JORDÃO, PESSOA, 2005).

Alguns parâmetros típicos dos esgotos no Brasil estão apresentados na Tabela 3.2 conforme descreveu Jordão e Pessoa, 2005. Porém é importante ressalvar que existe uma variação nas concentrações dos parâmetros do esgoto ao longo do ano. As variações são principalmente devido às variações das vazões dos esgotos nas redes coletoras provocadas pelas contribuições de águas de chuva, seja por infiltração seja por lançamento direto destas águas na rede de esgotos (prática muito comum no Brasil devido a ausência de fiscalização de obras).

Tabela 3.3 - Exemplo de valores típicos para parâmetros da caracterização de esgotos domésticos (mg/L).

\begin{tabular}{ccc}
\hline Mês & DBO $(\mathbf{m g} / \mathbf{L})$ & SST $(\mathbf{m g} / \mathbf{L})$ \\
\hline Janeiro & 131 & 137 \\
Fevereiro & 183 & 188 \\
Março & 150 & 172 \\
Abril & 133 & 149 \\
Maio & 174 & 241 \\
Junho & 139 & 152 \\
Julho & 268 & 377 \\
Agosto & 223 & 199 \\
Setembro & 358 & 287 \\
Outubro & 351 & 383 \\
Novembro & 227 & 202 \\
Dezembro & 178 & 208 \\
\hline
\end{tabular}

Fonte: Adaptado de JORDÃO e PESSOA, 2005.

Os compostos de nitrogênio e fósforo nos esgotos sanitários merecem uma atenção a parte. São denominados nutrientes os quais de importante conhecimento tanto para o processo de tratamento biológico dos esgotos quanto para o seu lançamento no corpo receptor.

Os nutrientes são necessários para tratamento biológico para o crescimento bacteriano. Portanto é necessário que estes estejam presentes nos esgotos. Nos esgotos domésticos tal condição é geralmente satisfeita, enquanto que nos efluentes industriais não, conduzindo a que a biomassa não desenvolva com desejado. 
Os esgotos sanitários apresentam normalmente de 20 à $85 \mathrm{mg}-\mathrm{N} / \mathrm{L}$ das quais 8 à $35 \mathrm{mg}-\mathrm{N} / \mathrm{L}$ são de nitrogênio orgânico e 12 à 50 mg-N/L são de nitrogênio amoniacal. Os esgotos mais recentes (frescos) são praticamente desprovidos de nitrito e nitrato, que podem resultar de transformações bioquímicas já na rede coletora de esgotos.

O fósforo aparece em águas naturais principalmente devido às descargas de esgotos sanitários. Nestes os detergentes superfosfatados empregados em larga escala domesticamente constituem a principal fonte $\left(15,5 \%\right.$ de $\left.\mathrm{P}_{2} \mathrm{O}_{5}\right)$, além da própria matéria fecal que é rica em proteínas.

No Brasil, os esgotos sanitários apresentam concentrações de fósforo normalmente na faixa de 6 à $10 \mathrm{mg}-\mathrm{P} / \mathrm{L}$. Nos Estados Unidos a concentração atinge a $15 \mathrm{mg}-\mathrm{P} / \mathrm{L}$, devio ao uso bastante difundido de detergentes domésticos. Aqui, o uso de detergentes é limitado pela condição econômica da população (PIVELI, 2005).

\subsection{3- Microrganismos no processo de lodo ativado}

Em sistemas de lodo ativado, embora o meio ambiente seja aquático os organismos presentes não são necessariamente o mesmo de ambientes naturais de águas doces. Isso porque o processo apresenta características específicas, como turbulência por causa da areação, e turbidez, devido ao material em suspensão.

Apenas a microfauna é encontrada nesses processos, pois a turbulência não permite o desenvolvimento de organismos maiores. A turbidez do meio provoca a ausência de luz, evitando o desenvolvimento de algas. Entre a microbiota normalmente são encontrados vários tipos de bactérias, entre elas as filamentosas, formando a biomassa e, às vezes, fungos e leveduras. As bactérias são organismos sapróbicos, consumidores primários que degradam a matéria orgânica do despejo, promovendo sua estabilização.

A presença da biofauna é um grande indício do funcionamento do processo e como um observador experiente pode identificá-la com certa facilidade, é utilizada como indicador biológico. A observação qualitativa e quantitativa da microfauna é realizada no controle do processo de lodo ativado.

O aspecto do lodo ao microscópico em geral pode ser descrito da seguinte forma: as bactérias se agregam formando flocos biológicos, que também congregam 
bactérias filamentosas. Na superfície desses flocos fixam-se os protozoários sésseis, ciliados pedunculados ou peritríquias. Há protozoários que vivem em estreita ligação com os flocos, alimentando-se desses e mantendo-se sempre em torno deles, sem estar porém fisicamente à eles ligados (ciliados hipotriquias)Por último existem os ciliados livres nadantes que se movem nos espaços entre os flocos, os flagelados e as amebas. Os micrometazoários (rotíferos e pequenos vermes) também se locomovem, no geral nos espaços entre os flocos.

A natureza da microfauna presente é característica da idade do lodo. É também característica da saprocidade, nível de qualidade da água refletido pelas espécies que constituem a comunidade presente, de acordo com a matéria orgânica biodegradável, expressa em DBO. Assim uma determinada comunidade é determinada indicadora do nível saprobico de um determinado meio.

Outro fator importante à se considerar é a avaliação da concentração de bactérias filamentosas. Elas encontram-se quase sempre presentes nos flocos bacterianos, orem sua quantidade em relação aos flocos deve ser limitada a um certo ponto para que não ocorram problemas na sedimentação do lodo como o intumecimento filamentoso.

A microfauna é indicadora do conjunto de parâmetros de funcionamento do processo de lodo ativado, ima vez que sua natureza varia com o nível de depuração, co a concentração de oxigênio dissolvido, com a presença de substancias tóxicas, etc, dentro do tanque de aeração (VAZOLLER, 1989).

\subsection{4- Remoção da matéria orgânica}

A concentração e a composição do material orgânico das águas residuárias depende da natureza destas. Para o modelamento da remoção do material orgânico do processo de lodo ativado, torna-se necessário dividir a matéria orgânica (ex: DQO) afluente em diferentes frações, analisando-se o comportamento de cada fração individualmente.

Primeiramente divide-se a matéria orgânica afluente em material biodegradável e material não biodegradável, sendo que o primeiro pode ser metabolisado pelos microrganismos do lodo ativado, enquanto o segundo não é afetado pela ação bioquímica destes. Para uma descrição mais afinada do comportamento do lodo ativado torna-se necessário subdividir as frações 
biodegradável e não biodegradável do afluente. Esta subdivisão leva em consideração o tamanho físico do material biodegradável.

$\mathrm{Na}$ maioria das águas residuárias as partículas de material orgânico variam em tamanho, tendo-se parte do material na forma de uma solução verdadeira com moléculas relativamente pequenas, outra parte com moléculas que formam uma solução coloidal e uma terceira parte com partículas macroscópicas, formando uma suspensão. Com relação entre a interação do material orgânico e os flocos biológicos do sistema de lodo ativado, considera-se uma subdivisão entre o material dissolvido e o material particulado (coloidal e material em suspensão).

A razão dessa subdivisão é que os flocos de lodo ativado agem como um forte coagulante, resultando na remoção do material particulado pelo processo físico de coagulação e floculação: os flocos de lodo capturam as partículas e estas passam a fazer parte da fase sólida (o lodo ativado). Essa remoção física se dará independentemente do fato do material orgânico ser biodegradável ou não.

O exposto leva à conclusão que o comportamento do material não biodegradável e dissolvido será diferente daquele do material não biodegradável particulado, o primeiro não será afetado pelo lodo no sistema e será descarregado com o efluente e o segundo será floculado e acumulado no sistema de lodo ativado até a sua descarga com o lodo de excesso.

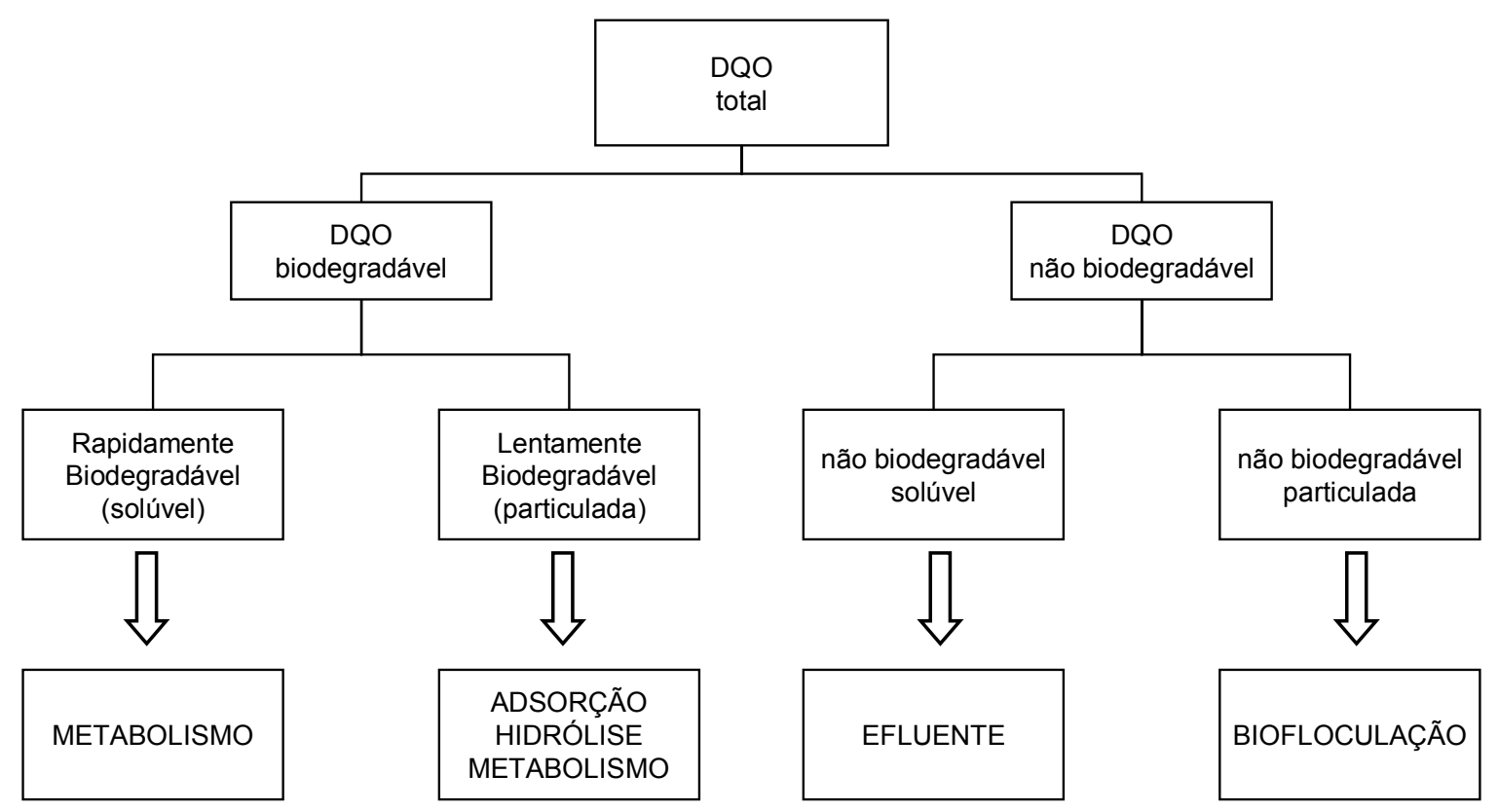

Fugura 3.10 - Representação das quatro frações do material orgânico e seus destinos no processo de lodo ativado (Fonte: adaptado de Metcalf \& Eddy, 2003) 
No caso do material biodegradável existe também uma diferença entre a fração dissolvida e a fração particulada. O pequeno tamanho das moléculas do material dissolvido permite a penetração pela parede celular das bactérias e o seu metabolismo direto. Em contraste o metabolismo do material particulado somente é possível após vários processos que incluem a floculação, adsorção à superfície dos microrganismos, hidrólise do material adsorvido com a conseqüente solubilização do material particulado e, finalmente, a utilização do material solubilizado. Conclui-se que a remoção física do material biodegradável das águas residuárias no sistema de lodo ativado seja realizada rapidamente, mas, no caso do material particulado, o metabolismo não será imediato. Dessa maneira distingue-se material rapidamente biodegradável (dissolvido) e material lentamente biodegradável (particulado) como ilustrado na Figura 3.10 (VAN HAANDEL, 1999).

Parta descrever o comportamento do sistema de lodo ativado, Marais e Ekama (1976) sugeriram uma subdivisão dos sólidos orgânicos do lodo ativado em duas frações básicas: (1) lodo ativo, composto de microrganismo atuantes no metabolismo de material orgânico e (2) lodo inativo composto de material orgânico em suspensão e que não exerce atividade metabólica. Trata-se de uma divisão teórica. O lodo ativo é gerado a partir da síntese de material orgânico do afluente (novos microrganismos). O lodo inativo compõe-se de material orgânico não biodegradável e pela sua origem pode ser dividido em duas frações: (a) o lodo inerte, que é gerado a partir do material orgânico do afluente particulado e não bio degradável, e (b) o resíduo endógeno, que se origina do decaimento do lodo ativo , (morte celular).

Quando um sistema de lodo ativado recebe uma carga constante de material orgânico, então neste sistema estabelece-se um regime estacionário. Como no regime estacionário não haverá acúmulo de material orgânico afluente, este será descarregado no efluente ou transformado em outros produtos. Quanto à transformação de material orgânico afluente tem-se basicamente duas possibilidades: (1) transformação em lodo orgânico através de processo bioquímico e físico e (2) oxidação para produtos inorgânicos.

O fluxo de material orgânico oxidado pode ser determinado através do consumo de oxigênio dissolvido pelo licor misto. Por definição tem-se que $1 \mathrm{Kg}$ de DQO é oxidado por $1 \mathrm{Kg}$ de $\mathrm{O}_{2}$. Portanto o fluxo de material orgânico oxidado será sempre numericamente igual ao fluxo de oxigênio consumido por essa oxidação. $O$ 
fluxo do $\mathrm{O}_{2}$ consumido é igual ao produto do volume do reator pela taxa de consumo de oxigênio (TCO), sendo esta igual ao consumo de oxigênio por unidade de tempo por unidade de volume e é um parâmetro que pode ser medido experimentalmente.

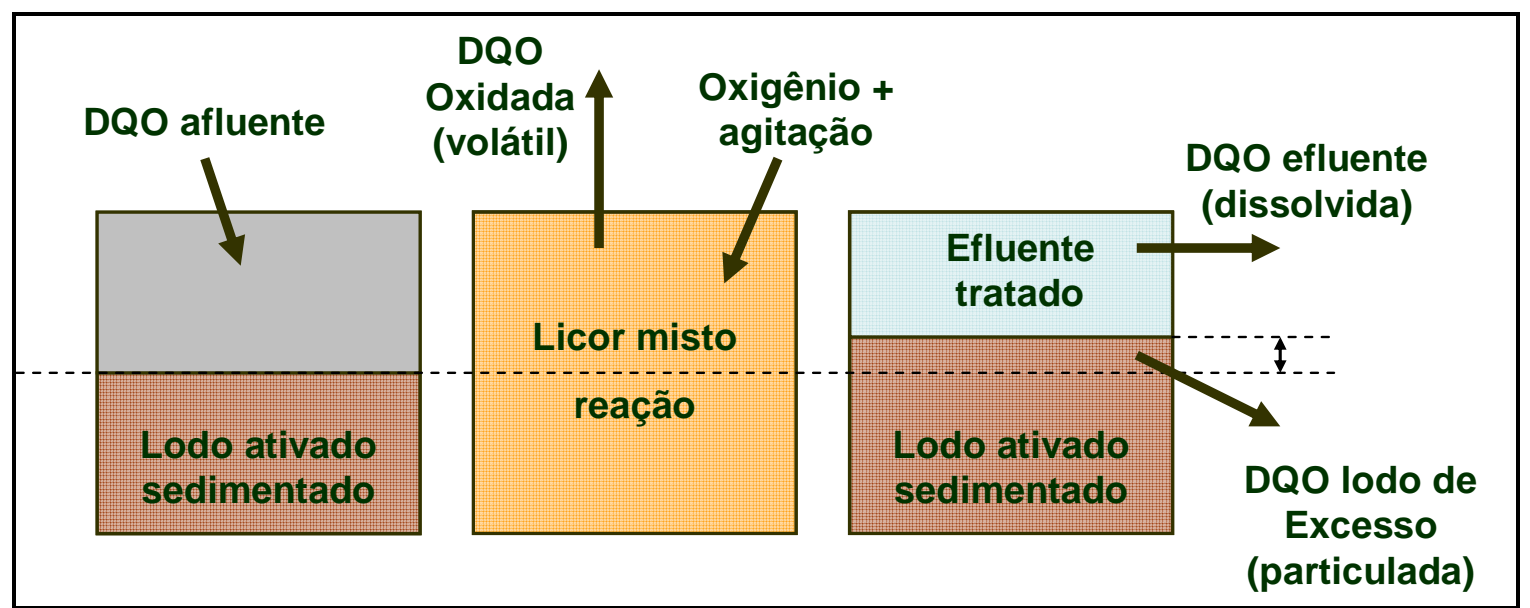

Figura 3.11 - Fluxograma esquemático da matéria orgânica em um sistema de lodo ativado

O metabolismo é resultante da incorporação de parte do material biodegradável para o crescimento celular (anabolismo) e da oxidação da outra parte do material biodegradável, ou respiração celular (anabolismo).

Postula-se ainda que haja o decaimento do lodo ativo independentemente dos processos metabólicos. O lodo ativo consome oxigênio para a sua própria oxidação, na ausência de matéria orgânica extracelular, chamado de decaimento celular e este consumo de oxigênio é chamado de respiração endógena (VAN HAANDEL, 1999).

O sistema de lodo ativado tem como parâmetro operacional mais importante a idade do lodo, que é a razão entre a quantidade de lodo existente no reator biológico e quantidade de lodo que cresce neste reator devido ao aporte de matéria orgânica por dia, ou ainda, considerando um sistema uniforme, é razão entre a quantidade de lodo existente no reator biológico e a quantidade de lodo retirada deste reator por dia através do descarte de lodo de excesso. Para apenas a remoção de matéria orgânica a idade do lodo deve estar na faixa de 3 à 5 dias, porém com temperaturas do licor misto entre 18 e $25^{\circ} \mathrm{C}$, atinge-se esta meta com 3 dias de idade do lodo, com um pequeno acréscimo na idade do lodo nesta última condição iniciar-se-á o processo de nitrificação no reator, consumindo para isso oxigênio. Em sistemas com aeração prolongada a nitrificação é inevitável (METCALF \& EDDY, 2003). 
Além do material orgânico o lodo volátil compõe de vários elementos, entre os quais o nitrogênio e o fósforo são os mais importantes. Os teores destes elementos no lodo orgânico não são constantes, mas pode-se dizer que varia em torno de 10 por cento para o nitrogênio e 2,5 por cento para o fósforo. Noentanto existem variações na qualidade do esgoto afluente e nos processo de lodo ativado, para o fósforo por exemplo pode atingir teores de até 38 por cento da massa do lodo orgânico (VAN HAANDEL, 1999).

Para a produção de lodo de excesso é necessário que na água residuária haja uma concentração mínima desses nutrientes de tal modo que se possa formar o lodo com teor de $\mathrm{N}$ e $\mathrm{P}$ de 10 e 2,5 por cento, respectivamente. No caso de águas residuárias domésticas as concentrações de nitrogênio e fósforo sempre são bem superiores que às mínimas necessárias para a produção de um lodo adequado. Tem-se encontrado na literatura a relação DBO : N : P de $100: 5: 1$, para sistemas de lodo ativado convencional e $100: 2,5$ : 0,5 para lodo ativado com aeração prolongada (VON SPERLING, 1997)

Outra relação importante para o controle operacional de um sistema de lodo ativado e a relação alimento / microrganismo (A/M), também chamado de fator de carga do lodo. Trata-se da relação entre a massa de matéria orgânica aplicada à uma massa de microrganismos por dia, podendo ser medida em $\mathrm{Kg}$ DQO / Kg SSVTA $x$ dia. Assim pode-se dizer que quanto maior a carga de substrato fornecido para uma determinada massa de micorganismos, menor será a eficiência na assimilação desse substrato. Inversamente, quanto menos alimento fornecido aos microrganiosmos, maior será a avidez pelo alimento, implicando numa maior eficiência da remoção de matéria orgânica. Na situação em que a quantidade do alimento é bem baixa passa a prevalecer o mecanismo d respiração endógena, característicos dos sistemas de aeração prolongada.

\subsection{5- Sedimentação do lodo}

Devido à alta concentração de sólidos em suspensão no lodo ativado a sua sedimentação em unidades decantadoras é de uma natureza completamente diferente daquela de suspensões mais diluídas (por exemplo o esgoto bruto em decantadores primários). Nas suspensões diluídas a interação entre as partículas que sedimentam é fraca e a velocidade de cada uma dependem das duas forças 
que agem sobre elas: (1) gravitacional devido ao seu peso aparente e (2) friccional devido à viscosidade da fase líquida. Em contraste nas suspensões mais concentradas como no licor misto, forma-se uma matriz de flocos interligados e essas sedimentam todas com a mesma velocidade: a velocidade de sedimentação em zona.

A etapa de sedimentação é fundamental para o processo de lodo ativado, geralmente é a última etapa do sistema de tratamento da fase líquida e esta etapa dita a qualidade do efluente final em termos de sólidos em suspensão, DBO e mesmo nutrientes. Os decantadores finais em um sistema de lodo ativado desempenham simultaneamente dois papéis: (1) a clarificação do efluente líquido que é resultado da separação da fese soída da fase líquida do licor misto e (2) o adensamento da fase sólida na unidade decantadora que é o aumento da concentração dos sólidos em suspensão durante a etapa de decantação. Dependendo das características de sedimentabilidade do lodo, uma o outra função limita a taxa máxima de sólidos que pode ser aplicada que, por sua vez, determina a área mínima necessária do decantador e, conseqüentemente, o seu volume.

Catunda et al (1989) realizaram uma investigação experimental para avaliar a influencia da concentração e composição de lodo ativado gerado a partir de esgoto municipal bruto sobre as constantes ligadas a sedimentabilidade de lodo. Entre as conclusões obtidas, ressalta-se que a concentração e a composição do lodo tem uma influência sobre as constantes de sedimentabilidade. A influência da concentração sobre as constantes é relativamente pequena, mas a composição do lodo influi marcadamente: um lodo com uma composição alta de lodo ativo tem um valor alto de $\operatorname{IVLA}_{3,5}$ (índice volumétrico do lodo agitado à uma concentração de sólidos em suspensão de $3,5 \mathrm{~g} / \mathrm{L}$ ) e conseqüentemente um valor alto de $\mathrm{K}$ e baixo de $v_{0}$ ( $K$ e $v_{0}$ são constantes de sedimentação em zona)ou seja quanto mais alta a fração de lodo ativo pior a sedimentabilidade do lodo (VAN HAANDEL, 1999).

\subsection{6- Tratamento e disposição final da fase sólida}

O gerenciamento do lodo de esgoto proveniente de estações de tratamento é uma atividade de grande complexidade e alto custo que, se for mal executada pode comprometer os benefícios ambientais e sanitários esperados destes sistemas. A importância desta prática foi reconhecida pela Agenda 21 que incluiu o tema 
"Manejo ambientalmente saudável dos resíduos sólidos e questões relacionadas com os esgotos", definindo as seguintes orientações para a sua gestão: a redução da produção, o aumento máximo da reutilização e da reciclagem e a promoção de depósitos e tratamento ambientalmente saudáveis.

Os principais tipos de resíduos sólidos gerados (lodo) no tratamento dos esgotos são: (1) o material gradeado, (2) areia, (3) escuma, (4) lodo primário, (5) lodo secundário e (6) lodo químico (caso haja etapa físico-química). O tratamento destes resíduos é uma etapa essencial no tratamento dos esgotos. Ainda que o lodo possa na maior parte das etapas do seu manuseio ser constituídos de mais de 95\% de água, apenas por convenção é designado por "fase sólida". A Tabela 3.4 contém as faixas de densidade do lodo de sistemas de lodo ativado.

Tabela 3.4 - Faixas de SVIST, \% de sólidos e densidade dos sólidos do lodo

\begin{tabular}{cccc}
\hline Tipo de lodo & $\begin{array}{c}\text { Relação } \\
\text { SVIST }\end{array}$ & $\begin{array}{c}\text { \% de sólidos } \\
\text { secos }\end{array}$ & $\begin{array}{c}\text { Densidade } \\
\text { dos sólidos }\end{array}$ \\
\hline Lodo primário & $0,75-0,80$ & $2-6$ & $1,14-1,18$ \\
Lodo secundário aeróbio (LA conv.) & $0,75-0,80$ & $0,6-1,0$ & $1,14-1,18$ \\
Lodo secundário aeróbio (aer. prol.) & $0,65-0,70$ & $0,8-1,2$ & $1,22-1,27$ \\
\hline
\end{tabular}

Fonte: Adaptado de ANDREOLI, 2001.

O lodo de esgoto em seu estado natural é muito rico em organismos patogênicos, facilmente putrecível e rapidamente desenvolve odores ofensivos. $O$ tratamento pode ser dividido em estabilização, desidratação e higienização (ANDREOLI, 2001).

A estabilização do lodo tem o objetivo de estabilizar a fração biodegradável da matéria orgânica presente no lodo, reduzindo o risco de putrefação, bem como diminuir a concentração de patógenos e pode ser realizada das seguintes maneiras: (1) estabilização biológica, (2) estabilização química e (3) estabilização térmica. No caso da estabilização biológica ainda é possível que seja realizada de maneira aeróbia, a digestão aeróbia, e de maneira anaeróbia, a digestão anaeróbia (LUDUVICE apud ANDREOLI, 2001).

A remoção de umidade é uma operação unitária fundamental para a redução de massa e de volume do lodo em excesso à ser tratado ou descartado da estação de tratamento de esgotos. No fluxo do lodo em uma ETE pode haver as seguintes etapas de remoção da umidade do lodo: (1) adensamento u espessamento e (2) 
desaguamento ou desidratação. O adensamento é mais comumente utilizado nos processos de tratamento primário, lodo ativado e filtro biológico percolador, 0 desaguamento é realizado com lodos já digeridos (GONÇALVES apud ANDREOLI, 2001).

A higienização do lodo de estação de tratamento de esgotos busca reduzir a patogenicidade do lodo à níveis que não venham causar riscos à saúde da população de acordo com as exigências para cada tipo de utilização do lodo. É importante salientar que o processo não é uma desinfecção, uma vez que não são desativados todos microrganismos patogênicos presentes no lodo. Os níveis de patogenicidade do lodo podem ser substancialmente reduzidos através dos processos de estabilização, como a digestão anaeróbia ou aeróbia, entretanto muitos parasitas intestinais e principalmente seus ovos são muito pouco afetados por processos de digestão convencional, necessitando uma etapa complementar ou conjugada aos processos convencionais para a sua completa inativação. Os mecanismos de higienização podem ser: (1) térmica, como compostagem, (2) química, como a calefação, (3) biológica, como a vermicultura e (4) a radiação (PINTO apud ANDREOLI, 2001).

O destino final do lodo gerado nas estações de tratamento de esgoto envolve estudos e decisões relativos ao acondicionamento e estabilização do lodo gerado, grau de desidratação, formas de transporte, eventual reuso no solo, eventuais impactos e riscos ambientais e aspectos econômicos desta destinação final. Entre as formas de disposição final do lodo de ETE's pode-se relacionar: (1) aterros sanitários, (2) incineração, (3) usos agrícolas, (4) uso industrial e (5) lançamento no oceano. Estas opções admitem soluções individualizadas ou combinadas de acordo com as características próprias da região em que se localizam as estações de tratamento de esgotos (JORDÃO E PESSOA, 2005). 


\section{3- Lançamento do lodo de ETA na ETE}

A indústria da água transforma a água inadequada para o consumo humano em um produto que esteja de acordo com os padrões de potabilidade, utilizando para isso processos e operações com a introdução de produtos químicos e gerando resíduos. Aquela mesma indústria tem questionado a preservação da qualidade da água bruta captada, através de ações que lhe garanta a proteção dos mananciais, por outro lado lança seus resíduos nos corpos d'água sem se preocupar com seus questionamentos levantados anteriormente. Porém ela também deve ter a preocupação da preservação para garantir a sustentabilidade de sua atividade.

Segundo o Sistema Nacional de Informações sobre Saneamento (SNIS, 2002), através do Diagnóstico dos Serviços de Água e Esgotos, realizado em 2002, no Brasil, cerca de $75,3 \%$ do total de municípios (5.561 municípios) e $94,3 \%$ da população urbana nacional dispõe de serviços de água. Em termos de serviços de esgotos, esses percentuais são de $17,4 \%$ e $71,0 \%$, respectivamente, comoilustrado na Figura 3.12.

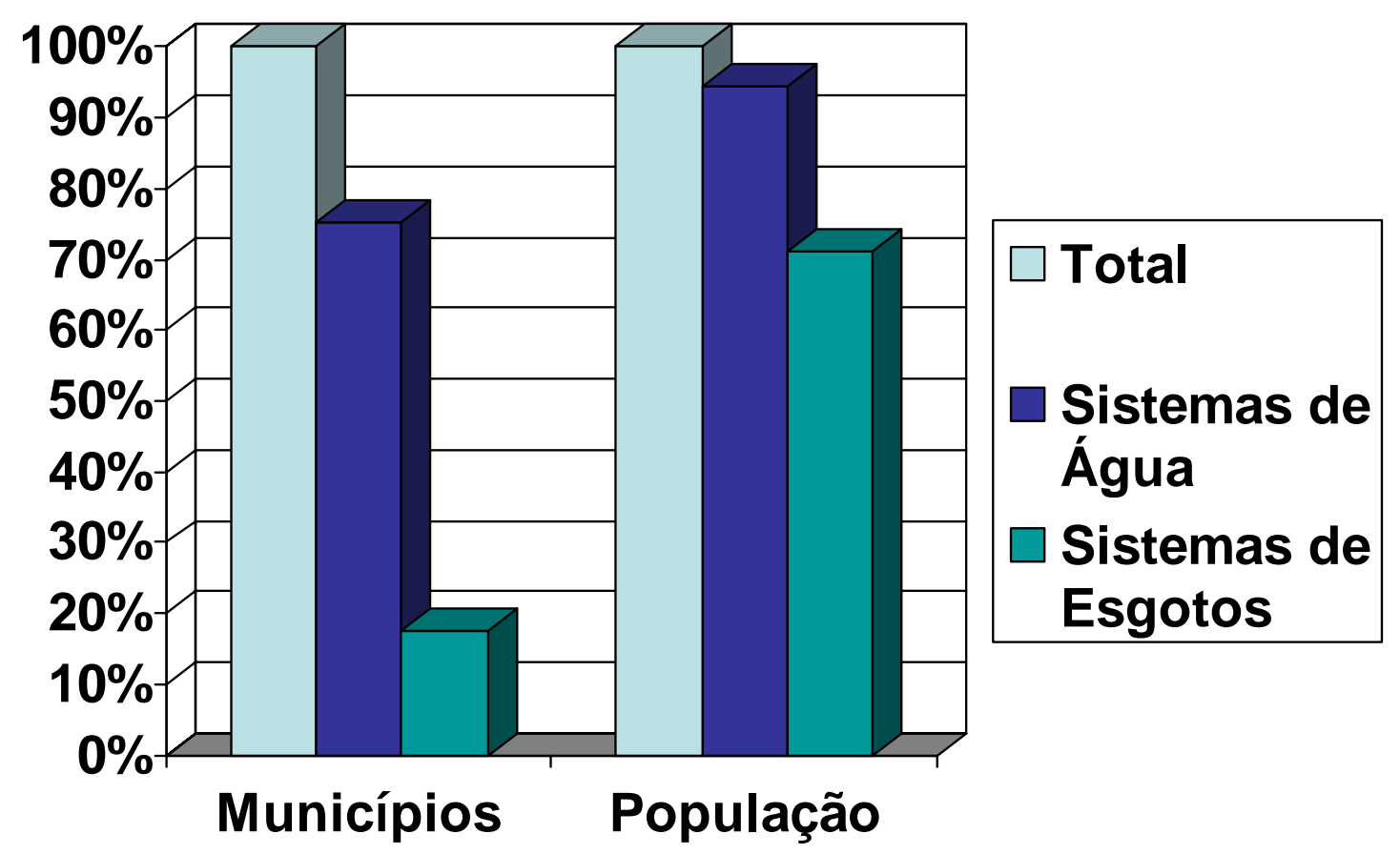

Figura 3.12 - Situação do saneamento no Brasil (Fonte: adaptado de SNIS, 2002) 
setor de saneamento, além representar importância fundamental à saúde pública, representa uma parcela significativa da economia brasileira. A indústria da água gera na ordem de 160 mil empregos diretos e indiretos, receitas e investimentos (SNIS, 2002).

Existem cerca de 7.500 estações de tratamento de águas convencionais no Brasil, destas quando utilizam o tratamento convencional (coagulação, floculação, sedimentação e filtração), geram resíduos originários da lavagem dos floculadores, dos decantadores, dos filtros e na lavagem dos tanques de preparação de soluções de produtos químicos. Estes resíduos têm sido geralmente dispostos próximos às estações, em cursos d'água, sem nenhum tratamento. Mas, este procedimento tem sido questionado, principalmente, devido a possíveis riscos à saúde pública e à vida aquática. Além disso, de acordo com a norma NBR - 10.004, estes lodos são classificados como resíduos sólidos exigindo manuseio e destinação adequados conforme exigências dos órgãos reguladores. O lançamento direto dos lodos nos cursos d'água infringe os dispositivos legais, tais como: a Lei Federal de Crimes Ambientais n 9605/98; no Estado de São Paulo a Lei 997/76, e seu regulamento Decreto 8.468/76; a resolução CONAMA 357/2005 e a Constituição Federal, 1989.

A visão existente nas gerencias de sistemas de tratamento tem sido restrita ao produto final, não havendo maior preocupação com medidas como: proteção efetiva dos mananciais; qualidade dos produtos químicos empregados e quantidade e características dos resíduos gerados (PARSEKIAN, 1998).

Existem diferente soluções técnicas para o tratamento e disposição do lodo de ETA como: condicionamento, adensamento e desidratação, aterro especial; utilização em solos; compostagem; utilização em pavimentação; fabricação de cimentos; fabricação de cerâmicas; lançamento em sistemas de esgotos entre outras. Muitas destas apresentam altos custos de transporte e de ampliação de instalações. Quando existe em um município uma planta dos sistemas de tratamento de água e de coleta e tratamento de esgotos favoráveis ao lançamento daqueles resíduos nos sistemas de esgotos, tem-se uma alternativa previamente mais econômica. Previamente porque os resultados finais deste procedimento não são totalmente certos e estão em estudo em algumas instituições do país.

Esta prática não resolve o problema do gerenciamento do resíduo da ETA, transfere o gerenciamento do tratamento e disposição do lodo da ETA para a ETE (REALI, 1999). Porém muitas vezes a ETA está colocada em área urbana e existe 
no sistema de esgotos uma ETE com toda infra-estrutura montada para o tratamento e disposição dos lodos devido as grandes quantidades geradas e também pela tradição da operação de lodos em ETE's, desse modo, esta opção se torna atrativa economicamente (JANUÁRIO, 2005).

Muitas ETA's, nos Estados Unidos lançam seus resíduos em redes coletoras de esgotos e em ETE's, estas opções são muitas vezes atrativas economicamente. A AWWA e a Water Industri Database (1992) em vistoria das ETA's que lançam seus resíduos em ETE's relatou que tais plantas variam bastante em tamanho e que na maioria dos casos captam água de superfície para o tratamento. Notou-se que as preocupações dos gerentes das ETE's são bem diferentes dos gerentes das ETA's, enquanto nas ETA's a preocupação está em se desfazer rapidamente dos resíduos, de modo que qualquer alternativa tomada não há interferência na qualidade do seu produto, a água tratada, nas ETE's existe a preocupação de como os resíduos chegam, em que condições hidráulicas, concentrações, características químicas, em que ponto do processo e qual a disposição final se dará. Tudo isso pelo fato de que algumas opções adotadas causam interferência no produto desta atividade, seja no efluente tratado da fase líquida, seja no da fase sólida.

O lançamento dos resíduos no sistema de esgotos é muitas vezes atrativos para os gerentes de ETA's devido alguns benefícios do ponto de vista legal e operacional. Entretanto, isto não tem sido universalmente sido aceito pela comunidade dos esgotos contanto que as ETA's cumpram com os requisitos de prétratamento e descarga nos sistemas de esgotos, uma vez que ela absorve toda a responsabilidade pelo processamento dos resíduos.

Alguns custos que envolvem esta opção são a instalação de reservatórios de equalização dos resíduos para o lançamento seja em redes coletoras de esgotos, seja em estações elevatórias ou de bombeamento para pontos específicos de uma ETE (ASCE, 1996).

O sistema de esgotos, por sua vez, deve tanto comportar o transporte do lodo de ETA até a ETE, via rede coletora, tendo como alguns dos fatores decisivos as condições hidráulicas de lançamento, horários de lançamento e concentração de sólidos no lodo de ETA, quanto à capacidade de recebimento das cargas extras no processo de tratamento das fases líquida e sólida dos esgotos, sendo isto o objeto deste estudo. 
Dentre as experiências nacionais, pode ser citado o caso da ETE do município de Franca operado pela SABESP (CINTRA FILHO, 2004). O lodo de ETA (tendo como coagulante cloreto férrico) é recebido em batelada pelo sistema de lodos ativados convencional mediante uma programação antecipada e diretamente para um decantador primário reservado. Foram estudados alguns efeitos da disposição do lodo nos decantadores primários, tanques de aeração e digestores secundários: aumento da concentração de sólidos suspensos no tanque de aeração, eficiência de remoção de DQO e DBO se manteviveram estáveis, diminuição do teor de matéria orgânica, etc. Pode ser citado também Carvalho (1999) que estudou a interferência do lodo de ETA com cloreto férrico em uma ETE no desempenho dos decantadores primários e digestores de lodo e verificou-se que o lodo não causou efeito prejudicial ao desempenho da ETE.

Scalize (2003) estudou a influência da disposição de lodo de ETA (sulfato de alumínio) em colunas de sedimentação com e sem lançamento de lodo de ETA (primeira fase) e verificou que o sobrenadante da coluna com lançamento de lodo de ETA apresentava uma maior redução na concentração dos parâmetros cor, turbidez, SST, SSV e DQO, além de coliformes totais, Escherichia coli, ovos de Ancylostomidae e larvas de Strongylaides. Na segunda fase do trabalho, numa estação piloto composta de lagoa de aeração seguida de lagoa de sedimentação, foi adicionado ao sistema lodo da ETA (cloreto férrico) e foi verificado que tal resíduo melhorou a qualidade do efluente em termos de DQO, DBO, SST, turbidez, cor, amônia, nitrato, NTK e fosfato total.

Além da maior remoção de sólidos suspensos nos decantadores primários, registra-se, também, maior remoção de DBO e DQO e uma maior eficiência na remoção de fósforo quando lodo contendo alumínio ou ferro são lançados em ETE's (ECKHART, 1988 apud CORNWELL e KOPPERS, 1990). O sulfeto de hidrogênio é um gás problemático em sistemas de esgotos, pois apresenta odor ofensivo já em concentrações de 0,1 ppm e, em concentrações maiores, pode causar danos físicos ao homem, além de causar sérios problemas de corrosão em estruturas de metal e concreto.

Pesquisas e aplicações práticas na Holanda de Alemanhamostraram que o lodo de ETAs contendo ferro podem ser efetivos no controle de sulfetos em coletores de esgotos e nos tanques de digestão das ETEs, em substituição ao cloreto férrico, normalmente utilizado (CORNWELL e KOPPERS, 1990), sendo um benefício do 
lançamento do lodo de ETAs no sistema de coleta e tratamento de esgotos (JANUÁRIO, 2005).

Brink (2003) observou que tecnicamente, são viáveis o condicionamento e a desidratação de lodos de ETA em conjunto com lodos de ETE (na proporção de massa de sólidos no lodo da ETA por massa de sólidos de lodo de ETE de 25\%), não verificando nenhum efeito prejudicial à etapa de desidratação em relação a operação do sistema somente com o lodo de ETE. Relatou ainda que eventuais pioras na eficiência da desidratação podem ser corrigidas com um aumento da dosagem de produtos químicos (polímeros) durante a etapa de condicionamento (JANUÁRIO, 2005).

Quadro 3.1 - Caracterização semi-quantitativa por FRX, de amostras de lodo provenientes de diferentes ETA's pertencentes à bacia hidrográfica do Rio Ribeira de Iguape. (REIS, 2005).

\begin{tabular}{|c|c|c|c|c|c|}
\hline \multirow{3}{*}{$\begin{array}{c}\text { Composição } \\
\text { Química }\end{array}$} & \multicolumn{5}{|c|}{ Concentraçao (\%)* } \\
\hline & \multicolumn{2}{|c|}{ Lodo ETA Registro } & \multirow{2}{*}{$\begin{array}{c}\text { Lodo ETA } \\
\text { Pariqueraçu }\end{array}$} & \multirow{2}{*}{$\begin{array}{l}\text { Lodo ETA S. } \\
\text { Lourenço da } \\
\text { Serra }\end{array}$} & \multirow{2}{*}{$\begin{array}{l}\text { Lodo ETA } \\
\text { Juquitiba }\end{array}$} \\
\hline & Fev./2004 & Ago./2004 & & & \\
\hline $\mathrm{SiO} 2$ & 31,5 & 32,5 & 28,4 & 19,6 & 24,2 \\
\hline $\mathrm{Al} 2 \mathrm{O} 3$ & 23,7 & 23,8 & 21,1 & 25,5 & 27,8 \\
\hline $\mathrm{Fe} 2 \mathrm{O} 3$ & 11,8 & 11,4 & 11,7 & 17,1 & 16 \\
\hline $\mathrm{K} 2 \mathrm{O}$ & 2,6 & 2,7 & 2,6 & 1,5 & 2,1 \\
\hline $\mathrm{TiO} 2$ & 1 & 1,2 & 0,96 & 0,79 & 0,85 \\
\hline $\mathrm{MgO}$ & 0,95 & 1 & 0,41 & 0,39 & 0,21 \\
\hline So3 & 0,93 & 0,68 & 1,2 & 0,76 & 0,54 \\
\hline $\mathrm{CaO}$ & 0,35 & 0,59 & 0,075 & 0,25 & 0,094 \\
\hline $\mathrm{Cl}$ & 0,37 & 0,46 & 0,095 & 0,52 & 0,16 \\
\hline $\mathrm{P} 2 \mathrm{O} 5$ & 0,42 & 0,46 & 0,29 & 0,52 & 0,38 \\
\hline $\mathrm{Na} 2 \mathrm{O}$ & 0,21 & 0,27 & 0,17 & 0,1 & 0,1 \\
\hline $\mathrm{MnO}$ & 0,18 & 0,17 & 0,062 & 0,46 & 0,44 \\
\hline $\mathrm{Cr} 2 \mathrm{O} 3$ & 0,029 & 0,033 & 0,022 & 0,015 & 0,019 \\
\hline $\mathrm{Rb} 2 \mathrm{O}$ & 0,018 & 0,027 & 0,006 & 0,003 & 0,003 \\
\hline $\mathrm{NiO}$ & 0,013 & 0,015 & 0,008 & 0,007 & 0,012 \\
\hline $\mathrm{PbO}$ & - & 0,014 & - & - & 0,019 \\
\hline $\mathrm{ZnO}$ & 0,02 & 0,023 & 0,009 & 0,013 & 0,013 \\
\hline $\mathrm{Br}$ & 0,008 & 0,012 & 0,011 & 0,048 & 0,011 \\
\hline $\mathrm{CuO}$ & 0,013 & 0,011 & 0,006 & 0,008 & 0,01 \\
\hline $\mathrm{SrO}$ & 0,005 & 0,009 & 0,002 & 0,001 & 0,002 \\
\hline $\mathrm{ZrO} 2$ & 0,007 & 0,008 & 0,008 & 0,009 & 0,005 \\
\hline Ga2O3 & 0,008 & 0,008 & 0,005 & 0,005 & 0,01 \\
\hline $\mathrm{Nb2O5}$ & 0,0005 & 0,0004 & 0,0005 & 0,0009 & 0,0005 \\
\hline V2O5 & - & - & - & 0,044 & 0,043 \\
\hline As2O3 & - & - & 0,004 & 0,006 & - \\
\hline Y2O3 & - & - & - & 0,002 & - \\
\hline Perda ao fogo & 25,8 & 25,8 & 32,8 & 32,4 & 26,9 \\
\hline
\end{tabular}

*Amostra previamente seca à $55-60^{\circ} \mathrm{C}$ e calcinada à $900^{\circ} \mathrm{C}$ por 1 hora.

Fonte: REIS, 2005. 
Uma importante consideração que deve ser feita é quanto à qualidade do lodo de ETA em geral. Ele apresenta baixa concentração de matéria orgânica biodegradável e alta concentração de sólidos em suspensão inertes, isso significa que, quando lançado em ETE's, diretamente no processo de tratamento da fase líquida, as unidade de tratamento trabalham com um maior quantidade de sólidos em suspensão, porém, continuarão tratando a mesma quantidade de matéria orgânica. Esses sólidos terão uma menor relação SSVISST e deverão ser calculados e conhecidos com a finalidade de: saber até quanto pode se aumentar a concentração de sólidos num reator, ou numa unidade de decantação, ainda, que vazão adicional será suportada pelas unidades da ETE, a fim de se evitar um colapso.

Reis et. al, 2004 e Reis, 2005, realizaram trabalhos que fundamentam os estudos de recursos hídricos e de saneamento, no que tange a disposição do lodo geado em estações de tratamento de água, sendo a caracterização química destes lodos apresentada no Quadro 3.1, onde possibilita identificar individualmente seus componentes, as diferenças existentes entre mananciais. Identificou-se ainda a fração de perda ao fogo na ordem de $25-30 \%$.

Em relação aos efeitos tóxicos que podem apresentar o lançamento do lodo de ETA's em ETE's, uma potencial toxicidade para o processo biológico se aplica, primeiramente pela descarga da fase líquida dos resíduos de ETA's nas ETE's. Os sólidos presentes nos resíduos líquidos podem estar disponíveis numa forma e presentes em concentrações suficientes para impedir o processo biológico. A determinação dos efeitos de toxicidade dos compostos inorgânicos no processo biológico de tratamento de esgotos não é um procedimento simples. Uma carga de choque inicial devido compostos tóxicos podem ter efeitos inibitórios no processo biológico, entretanto os microrganismos podem se adaptar e se ajustar devido a presença contínua do íon inorgânico. Concentrações limiares de íons tóxicos no processo biológico estão um nível acima do qual ocorre uma diminuição da eficiência da remoção de DQO. Os Resíduos líquidos podem conter fluoretos, bário, nitrato, arsênio, rádio e SDT. Cargas com taxas de nitrato podem ser consideradas problemas se a ETE opera com desnitrificação (CORNWEL, 1987).

Num estudo em escala real realizado por Rolan, foi adicionado por 60 dias o lodo de alumínio no fluxo de esgotos. O lodo de alumínio foi medido por uma dosagem na qual aumentou a concentração de SS no esgoto bruto de $100 \mathrm{mg} / \mathrm{L}$. 
Nenhum efeito foi encontrado na DBO do efluente final, já os SS aumentaram de $20 \mathrm{mg} / \mathrm{L}$ para $40 \mathrm{mg} / \mathrm{L}$. Após a interrupção da aplicação do lodo e alumínio a concentração de SS no efluente final retornou, imediatamente aos $20 \mathrm{mg} / \mathrm{L}$. A cor teve um aumento de 45 à 59 UNC para 70 à 90 UNC e o fósforo total teve uma diminuição de sua concentração no efluente final de $7 \mathrm{mg} / \mathrm{L}$ para $4 \mathrm{mg} / \mathrm{L} \mathrm{com} \mathrm{a}$ aplicação do lodo de alumínio (CORNWEL, 1987). 


\section{4- Material e métodos}

\section{1- Considerações iniciais}

A pesquisa foi desenvolvida foi desenvolvida basicamente em atividades em campo nas estações de tratamento de água e de esgotos do município de Juquitiba - SP e no Laboratório de Saneamento "Prof Lucas Nogueira Garcez", do Departamento de Engenharia Hidráulica e Sanitária da Escola Politécnica - USP. Para a utilização das estruturas existentes no município de Juquitiba - SP, foi concedido pela SABESP, a concessionária responsável pelos sistemas, a autorização para o desenvolvimento da pesquisa nestas unidades.

\section{2- Plano de trabalho}

O plano de trabalho foi dividido em três etapas: $\left(1^{a}\right)$ o reconhecimento das estações de tratamento de água e de esgoto para as promover as adequações ao desenvolvimento deste projeto de pesquisa, $\left(2^{a}\right)$ a caracterização do lodo da estação de tratamento de água, do esgoto bruto afluente, do lodo ativado do reator biológico, do efluente final e do lodo de excesso da ETE, antes do início do lançamento do lodo da ETA no sistema de esgotos e $\left(3^{a}\right)$ caracterização do esgoto bruto afluente, do lodo ativado do reator biológico, do efluente final e do lodo de excesso da ETE, após o início do lançamento do lodo da ETA no sistema de esgotos.

\subsection{1- Caracterização do lodo da ETA}

A estação de tratamento de água de Juquitiba é do tipo convencional, com etapas de coagulação, floculação, decantação e filtração e utiliza sulfato de alumínio como coagulante. Nela existe um sistema de descarte de lodo de lavagem dos floculadores, decantadores e filtros diretamente ligado à galeria de águas pluviais. Para o desenvolvimento deste projeto de pesquisa, se fez necessário a inclusão na ETA de um reservatório de regularização de vazão deste lodo, tornando possível o seu lançamento na rede coletora de esgotos. 
Inicialmente foram levantados os dados de operação da ETA Juquitiba, tais como: vazão de água bruta captada, dimensões das unidades floculadoras e decantadoras, volumes de água utilizada nos procedimentos de limpeza dos floculadores, decantadores e filtros, consumo de coagulante para o tratamento da água e freqüências dos procedimentos de limpezas das unidades. Foram levantados dados de turbidez da água bruta e características físico-químicas do lodo gerado pelas unidades de tratamento da estação, como, sólidos em suspensão totais, fixos e voláteis, DQO, fósforo total, nitrogênio Kjeldhal total, $\mathrm{pH}$ e alcalinidade. Foram também realizadas outras análises químicas no Laboratório de Análises Químicas e Ambiental e Laboratório de Fluorescência de Raios-X, ambos localizados no CQMAIPEN, com a finalidade de identificar elementos e compostos presentes no lodo.
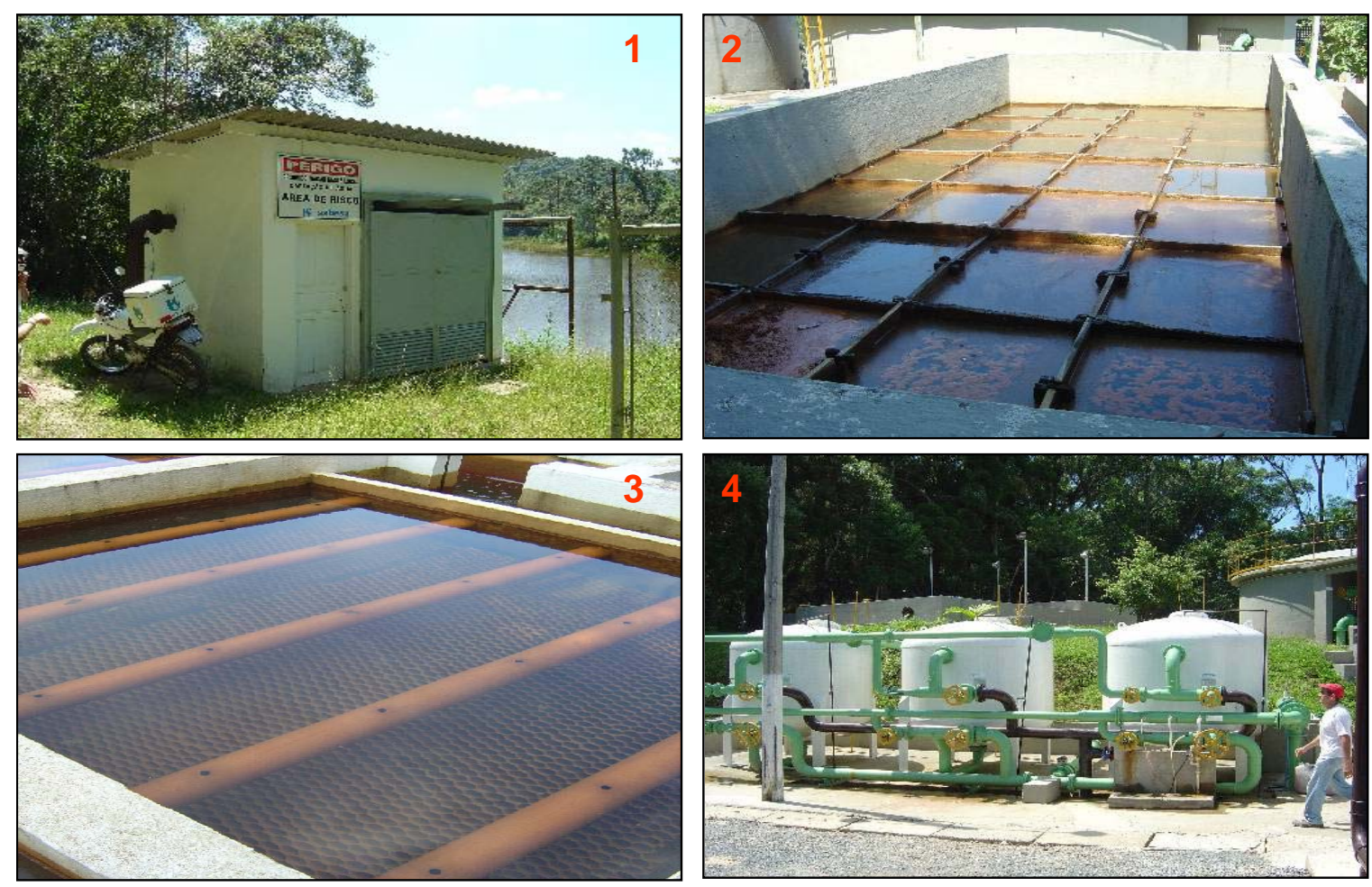

Figura 4.1 - Seqüência das unidades produtoras de água tratada do sistema de tratamento de água de Juquitiba: 1- estação de captação de água bruta; 2- floculadores, 3- decantador $n^{\circ} 2$ e 4- bateria de filtros

O dimensionamento do reservatório de equalização, ou regularização das vazões dos descartes dos líquidos de lavagem das unidades da ETA levou à conclusão de que seriam necessários $80 \mathrm{~m}^{3}$ para este fim. Porém, foi construído um 
reservatório de $30 \mathrm{~m}^{3}$ na ETA capaz de atender a regularização apenas das vazões das águas de lavagem dos filtros para o lançamento na rede de esgotos.

O procedimento de lavagem da unidade floculadora não foi realizado enquanto decorreu a pesquisa, portanto não há necessidade de sua descrição. O procedimento de lavagem das unidades decantadoras tem freqüência mensal, é realizado no período da tarde pela necessidade de ter que parar o tratamento de água durante o procedimento de lavagem e é neste período que o reservatório de água tratada encontra-se com o nível mais alto ao longo do dia. Este procedimento inicia-se desligando as bombas da estação de captação seguido da abertura das válvulas de descarte do lodo dos decantadores. Enquanto o nível da água diminui nos decantadores o operador faz a limpeza das telhas e das paredes com jato de água pressurizada, Figura 4.2. Quando toda água escoou dos decantadores é feita a raspagem do lodo restante com enxada e jato de água, encaminhando-o para a tubulação de descarte, até a sua remoção total. As águas descartadas dos decantadores pelo procedimento de lavagem são escoadas por gravidade do início ao final do procedimento, levando para isso de 2 à 4 horas. Após isso reinicia-se o tratamento de água com o ligamento das bombas da estação de captação.

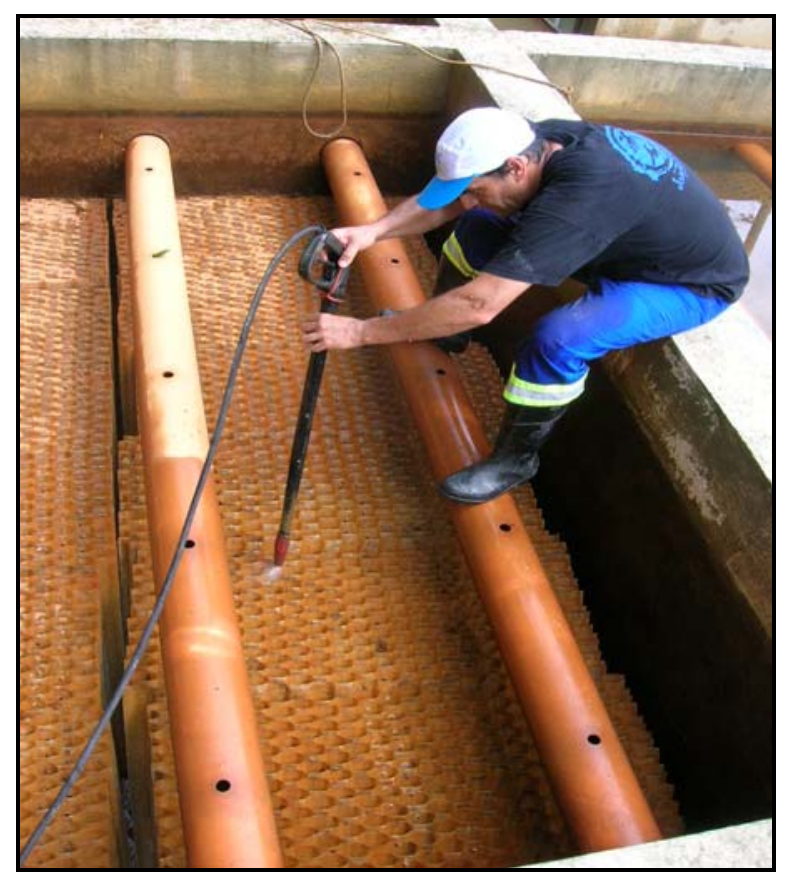

Figura 4.2 - Lavagem da unidade decantadora da ETA Juquitiba

O Procedimento de lavagem dos filtros é realizado diariamente no período da manhã com o tratamento de água em andamento. Existem três filtros em paralelo e 
realiza-se a lavagem de um filtro de cada vez, sendo lavados apenas dois filtros por dia. Trata-se de um procedimento semi-automatizado e pressurizado, onde 0 operador manobra as válvulas manualmente e aciona o comando das bombas. A lavagem de cada filtro leva aproximadamente 10 minutos.

Para as águas de lavagem dos decantadores e floculadores foi construído um canal que encaminha estas águas para a rede coletora de esgotos, com a seguinte conFiguração: seção 60 × $50 \mathrm{~cm}$ (já existente, que encaminhava as águas de lavagem dos floculadores e decantadoes para a galeria de águas pluviais) com um anteparo e uma tubulação de $\varnothing 150 \mathrm{~mm}$ no seu final, interligando o canal à rede coletora de esgotos. Quando em função da abertura das válvulas de descarga das unidades floculadoras e decantadoras a vazão destes líquidos é maior do que a capacidade da tubulação da rede coletora ocorre o afogamento do canal, então o anteparo foi construído com uma calha vertedoura à aproximadamente $40 \mathrm{~cm}$ do funde do canal, onde os líquidos excedentes à capacidade da rede coletora de esgotos possam transbordar e seguir para a galeria de águas pluviais.

Os dados vazão de água bruta captada, água tratada, volume de água utilizada nas lavagens dos filtros, consumo de coagulantes e outros produtos químicos e a freqüência dos procedimentos de limpeza ou lavagem das unidades da ETA, foram fornecidas pela administração da estação. Os dados de turbidez da água bruta foram levantados em um relatório interno da SABESP (SABESP, 2003), uma vez que esta medição é feita e processada internamente à um programa controlador da dosagem dos sais coagulantes da estação, não sendo gerados relatórios com estes dados.

O volume da unidade floculadora não foi calculado por não ser realizada regularmente a limpeza desta unidade, já os volumes das unidades decantadoras foram calculados a partir de medições "in loco".

As determinações de sólidos em suspensão, DQO, fósforo total, nitrogênio total, $\mathrm{pH}$ e alcalinidade do lodo da ETA foram realizadas a partir de amostras coletadas de forma aleatória para o lodo da lavagem dos decantadores e, de forma composta (alíquotas de $500 \mathrm{~mL}$ a cada minuto), para o lodo dos filtros e o lodo das descargas diárias que são feitas, de forma rápida, do fundo dos decantadores. Estas coletas foram feitas no canal de encaminhamento destes líquidos para a galeria de águas pluviais quando realizadas antes da manobra de lançamento dos resíduos da 
ETA na rede coletora de esgotos e, no primeiro PV da rede coletora, quando realizadas após a manobra, como ilustrado na Figura 4.3.

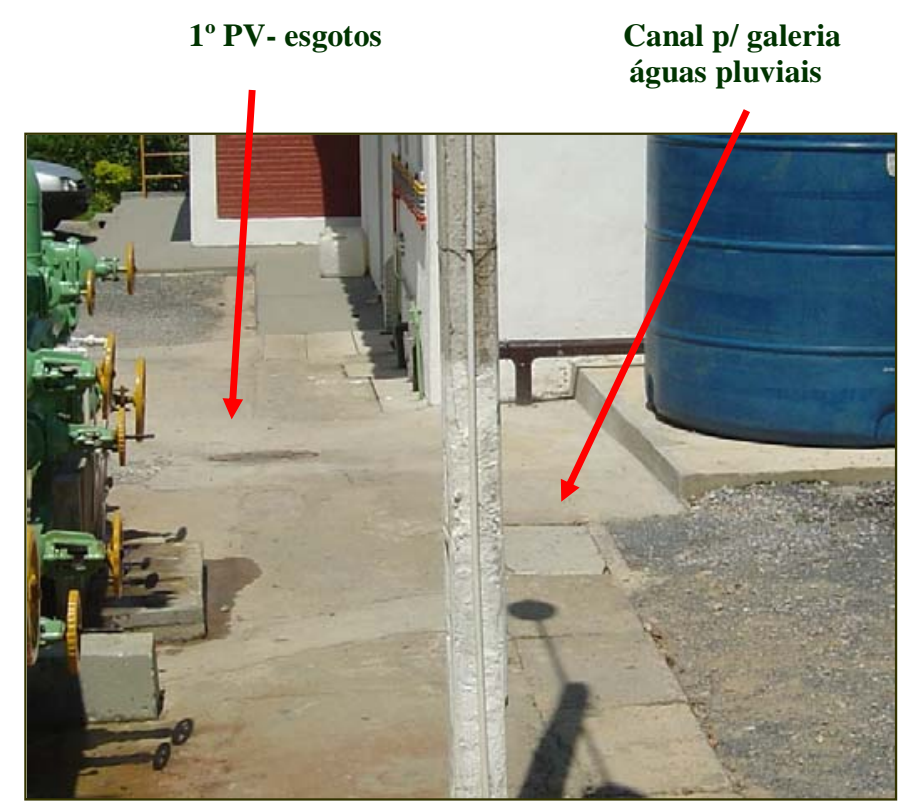

Figura 4.3 - Pontos de coletas dos resíduos da ETA

O levantamento da quantidade de lodo produzido pela ETA Juquitiba foi realizado através do cálculo da equação de Ferreira Filho e Alem Sobrinho (2005):

$$
P L=Q \cdot(4,89 \cdot D A L+S S+C A P+A O) \cdot 10^{-3}
$$

onde:

$P L=$ produção de lodo seco em $\mathrm{kg} / \mathrm{dia}$,

$\mathrm{Q}=$ vazão de água bruta em $\mathrm{m}^{3} /$ dia,

DAl = dosagem de sais de alumínio, expresso como Al em mg/L,

$\mathrm{SS}=$ concentração de sólidos em suspensão totais na água bruta em mg/L,

$\mathrm{CAP}=$ concentração de carvão ativado em pó em mg/L,

$\mathrm{OA}=$ outros aditivos em $\mathrm{mg} / \mathrm{L}$ (ex.: sílica ativada, polímeros, etc.). 


\subsection{2- Caracterização dos esgotos bruto, tratado e do lodo da ETE}

Identificou-se inicialmente que a ETE Juquitiba era operada com uma rotina de visitas semanais de um funcionário, o qual fazia a verificação dos equipamentos e checagem dos comandos eletrônicos.

Com o início da pesquisa adicionou-se em sua rotina a atividade de descarte de lodo de excesso dos reatores biológicos, para a manutenção da idade do lodo de 25 dias. Tendo sido observado a impossibilidade de se manter uma rotina de operação sustentável da maneira descrita, adotou-se elaborar um plano de ação para a ETE.

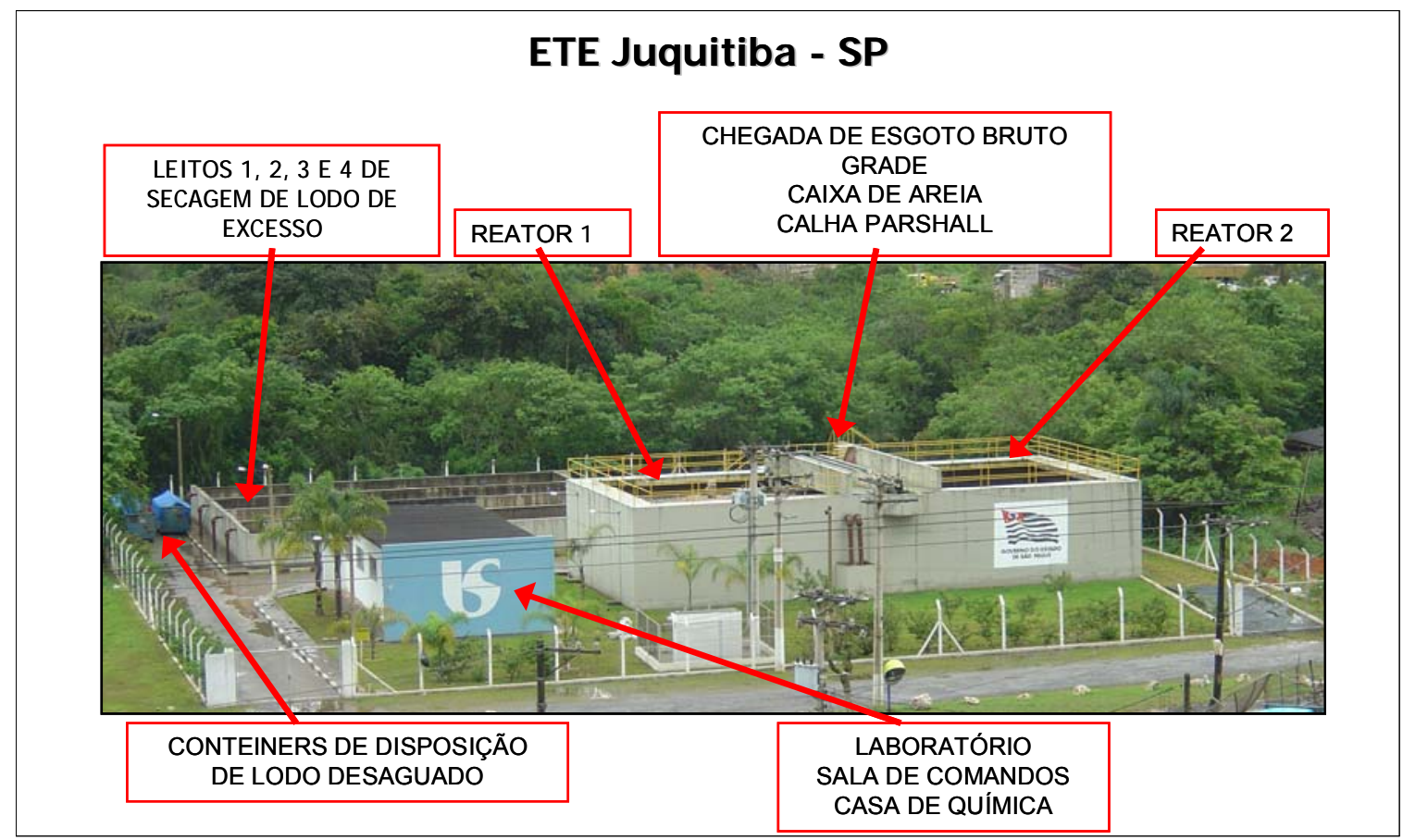

Figura 4.4 - Estação de tratamento de esgotos pelo processo e lodo ativado com dois reatores seqüenciais em bateladas

Em conjunto com a SABESP definiu-se aplicar as seguintes alterações na ETE Juquitiba: (1) alocar um funcionário exclusivo para a estação, sendo este o operador exclusivo da ETE Juquitiba; (2) instalar uma "grade" para remoção de sólidos grosseiros do esgoto bruto; (3) instalar um medidor eletrônico de vazões dos esgotos afluentes à ETE; (4) equipar a estação com ferramentas de limpeza (vassouras, rodos, esponjas, espátulas, etc.), com ferramentas para manutenção (pá, enxada, colher de pedreiro, etc.) e com equipamentos de laboratório (proveta 
graduada de 1 litro, cone Imhoff, béquer do 1 litro, termômetro, aparelho medidor re $\mathrm{pH}$, oxímetro e clorímetro); (5) um equipamento para retirada do efluente tratado da estação pela superfície do líquido do reator; (6) elaborar o caderno de campo e (7) orientar o operador para os procedimentos da nova rotina da estação.

Foi designado pela SABESP um operador nos cinco dias úteis da semana que continuou fazendo as verificações anteriormente referidas, mais: as análises diárias de sólidos sedimentáveis (cone Imhof) do esgoto bruto, de oxigênio dissolvido no tanque de aeração, $\mathrm{pH}$ e temperatura do esgoto bruto, do lodo do reator biológico e do efluente final, a retirada periódica do lodo de excesso do reator biológico, a operação e manutenção preventiva da estação como determinado no caderno de campo.

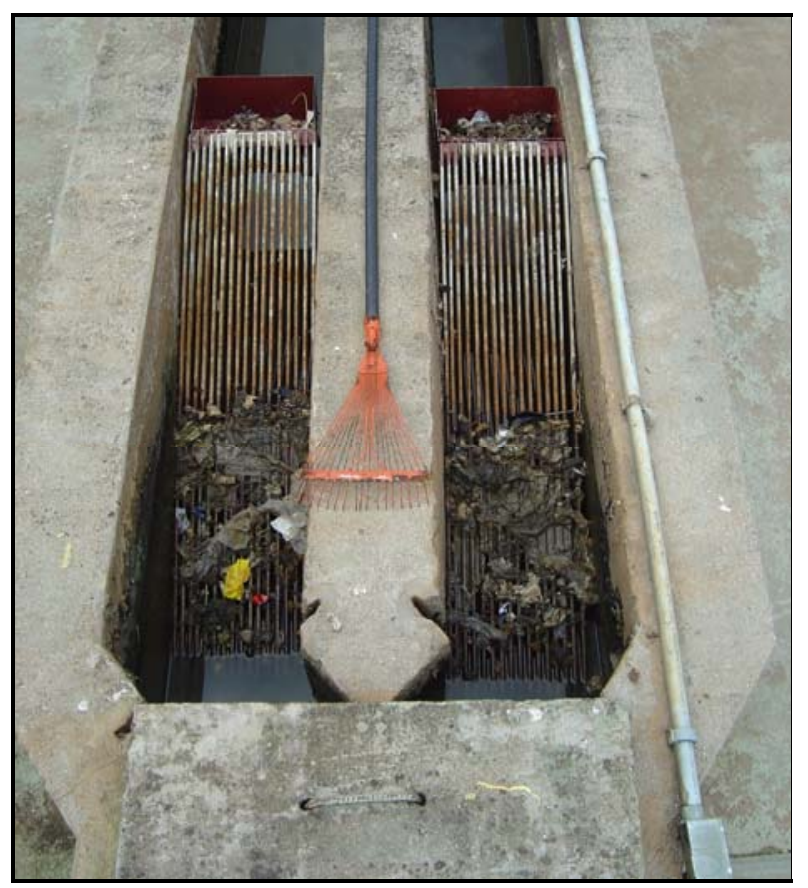

Figura 4.5 - Grade de remoção de sólidos grosseiros com limpeza manual

Na sua estrutura física, a ETE foi alterada com a implantação de uma grade de remoção sólidos grosseiros do esgoto bruto, Figura 4.5, à montante da caixa de areia; um medidor eletrônico de vazões e volumes (Nivelco) à jusante da caixa de areia, juntamente com a aquisição de um computador (PC) capaz de receber e processar as informações desse medidor, que foi considerado isto um importante passo para o controle da estação; a aquisição de equipamentos de análises laboratoriais de (1)oxigênio dissolvido, (2)pH, (3)temperatura, (4)sólidos 
sedimentáveis (cone Imhoff) e (5)provetas graduadas de um litro, assim como, baldes e cordas para coletas de amostras, beckers, frascos amostradores, pincetas para água destilada e álcool iodado.

Com tudo isso se deparou com mais um problema, os leitos de secagem do lodo de excesso não atenderam a necessidade da estação, de receber a quantidade de lodo para a manutenção da idade do lodo dos reatores biológicos de 25 dias. Foram levantadas alternativas para a solução do problema e a SABESP adotou a aquisição de "bag's" desaguadores de lodo, os quais deveriam ser instalados sobre o material drenante dos leitos de secagem.

Foi então adquirido e implantado o sistema desaguador de lodo de excesso do tipo "bag" (Geotube-USA) a fim de possibilitar o descarte necessário de lodo de excesso para atender a idade do lodo dos reatores biológicos de 25 dias. Para o funcionamento do novo sistema foi necessária a implantação de um sistema paralelo de mistura e dosagem de polímero na linha de descarte de lodo de excesso, para atender as necessidades do "bag" desaguador de lodo. Para a manutenção da idade do lodo do reator biológico da ETE em 25 dias, seria necessária a transferência diária de $15,7 \mathrm{~m}^{3}$ de licor misto dos reatores biológicos para o sistema desaguador de lodo. Com o início da pesquisa observou-se que os leitos de secagem não foram suficientes para este fim e encontrou-se a solução dos "bag" desaguadores, que atenderam essas necessidades.

A caracterização do esgoto bruto deu-se pela sua coleta imediatamente após a caixa de areia da ETE, como ilustrado na Figura 4.6, sendo a amostra uma composta de três coletas num dia: $1^{\mathrm{a}}$ às $8: 30 \mathrm{~h}, 2^{\mathrm{a}}$ às $11: 00 \mathrm{~h}$ e $3^{\mathrm{a}}$ às $14: 30 \mathrm{~h}$, utilizando para isso um Becker de 1 litro e um frasco amostrador de 3 litros. As coletas tiveram freqüência semanal e foram analisados os parâmetros: $\mathrm{pH}$ e temperatura no laboratório da ETE e sólidos em suspensão totais, fixos e voláteis, alcalinidade, $\mathrm{DQO}, \mathrm{DBO}_{5,20}$, nitrogênio total, nitrogênio amoniacal, nitrato, fósforo total e fósforo solúvel no laboratório de saneamento da EP-USP, das amostras coletadas, com freqüência semanal. 


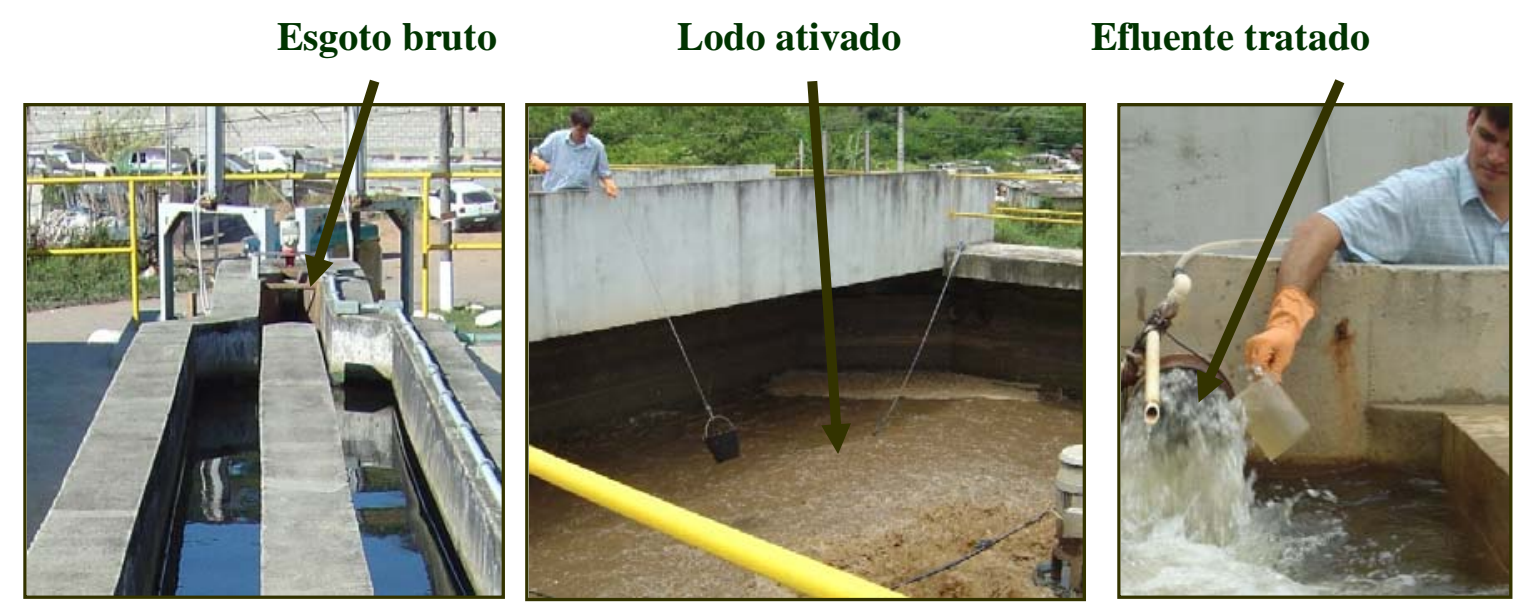

Figura 4.6 - Pontos de coleta das amostras da ETE Juquitiba

A caracterização do lodo ativado dos dois reatores biológicos da ETE foi realizada através das coletas diretamente nos reatores, como ilustrado na Figura 4.6, na fase do ciclo do processo de bateladas de reação, sempre no período da manhã. Fio utilizado uma corda e um balde de dez litros e dois frascos amostradores de 1 litro, um para cada lodo ativado dos dois reatores. As coletas tiveram freqüência semanal e foram analisados os parâmetros: oxigênio dissolvido, $\mathrm{pH}$ e temperatura no laboratório da ETE e sólidos em suspensão totais, fixos e voláteis e caracterização biológica do floco de lodo ativado, no laboratório de saneamento da EP-USP.

A caracterização do efluente tratado da ETE foi realizada através das coletas no final da tubulação de retirada do efluente tratado dos reatores biológicos e, imediatamente, antes da entrada destes efluentes no tanque de contato de cloro da ETE, como ilustrado na Figura 4.6, sempre no período da manhã. Foi utilizado um becker de 1 litro e 2 frascos amostradores de 1 litro, sendo um para cada efluente dos dois reatores. As coletas tiveram freqüência semanal e foram analisados os pelos parâmetros: ph e temperatura no laboratório da ETE e sólidos em suspensão totais, fixos e voláteis, alcalinidade, $\mathrm{DQO}, \mathrm{DBO}_{5}$, nitrogênio total, nitrogênio amoniacal, nitrato, fósforo total e fósforo solúvel, no laboratório de saneamento da EP-USP.

A caracterização do lodo de excesso foi considerada a mesma do lodo ativado dos reatores biológicos uma vez que o descarte deste lodo é feito diretamente dos reatores, quando estes se encontram em fase de aeração. 
Após ter sido calculada a produção de lodo da ETA e ter sido estimada a aplicação diária deste no sistema de esgotos, foi realizado um ensaio de "Jar-Test", no laboratório de saneamento da EP-USP, com a aplicação do lodo da ETA no esgoto bruto, preliminarmente ao início das etapas 2 e 3, descritas anteriormente. Este ensaio teve como finalidade obter dados prévios quanto à captura do fósforo total dos esgotos pelo lodo da ETE. O ensaio foi conduzido da maneira descrita na Tabela 4.1 .

Tabela 4.1 - Ensaio de Jar-Test de aplicação de lodo da ETA Juquitiba no esgoto bruto afluente à ETE

\begin{tabular}{ll}
\hline$N^{\circ}$ de jarros & 6 \\
Volume de esgotos nos jarros & 2 litros \\
Aplicação de lodo de ETA - J_1 & $0 \mathrm{mg} \mathrm{SST(ETA)} \mathrm{/} \mathrm{L} \mathrm{de} \mathrm{esgotos} \mathrm{(branco)}$ \\
Aplicação de lodo de ETA - J_2 & $25 \mathrm{mg} \mathrm{SST(ETA)} \mathrm{/} \mathrm{L} \mathrm{de} \mathrm{esgotos}$ \\
Aplicação de lodo de ETA - J_3 & $50 \mathrm{mg} \mathrm{SST(ETA)} \mathrm{/} \mathrm{L} \mathrm{de} \mathrm{esgotos}$ \\
Aplicação de lodo de ETA - J_4 & $75 \mathrm{mg} \mathrm{SST(ETA)} \mathrm{/} \mathrm{L} \mathrm{de} \mathrm{esgotos}$ \\
Aplicação de lodo de ETA - J_5 & $100 \mathrm{mg} \mathrm{SST(ETA)} \mathrm{/} \mathrm{L} \mathrm{de} \mathrm{esgotos}$ \\
Aplicação de lodo de ETA - J_6 & $150 \mathrm{mg}$ SST(ETA) / L de esgotos \\
Mistura rápida & 2 minutos à 300 rpm \\
Mistura lenta & 20 minutos à 30 rpm \\
Sedimentação & 1 hora \\
Coleta do sobrenadante p/ análise & 1 litro (pela altura média do jarro) \\
\hline
\end{tabular}

\subsection{3- Métodos analíticos}

As análises laboratoriais das amostras relativas ao lodo da ETA, esgoto bruto, lodos ativados do reator biológico e efluente final da ETE, foram realizadas no Laboratório de Saneamento "Prof Lucas Nogueira Garcez", do Departamento de Engenharia Hidráulica e Sanitária da Escola Politécnica e terão como referência para o seu desenvolvimento o manual Standard Methods for the Examination of Water and Wastewater, $18^{\mathrm{a}} \mathrm{Ed}$. (1995), As análises $\mathrm{pH}$ e temperatura do esgoto bruto, lodo dos reatores biológicos e efluente tratado, e oxigênio dissolvido do lodo dos reatores da ETE, foram realizadas no laboratório da ETE.

A freqüência das coletas, assim como das análises laboratoriais foi semanal, com a exceção do ensaio de caracterização biológica do floco de lodo ativado, que 
foi feito no início da operação do sistema. Os principais métodos analíticos e materiais utilizados estão listados na Tabela 4.2.

Tabela 4.2 - Métodos analíticos e material utilizado na determinação de parâmetros (continua)

\begin{tabular}{|c|c|c|}
\hline Parâmetros & Metodologia & $\begin{array}{l}\text { Equipamentos/ } \\
\text { Infra-estrutura }\end{array}$ \\
\hline $\mathrm{DBO}_{5}(\mathrm{mg} / \mathrm{l})$ & $\begin{array}{l}\text { Técnica das diluições sem semeadura e } \\
\text { incubação a } 20^{\circ} \mathrm{C} \text {. Determinação de } \\
\text { concentrações de OD pelo método } \\
\text { eletrométrico }\end{array}$ & $\begin{array}{c}\text { Frascos DBO Wheaton } \\
\text { Câmara Incubadora } \\
\text { BOD Mod } 347 \mathrm{CD} \text {, } \\
\text { FANEMI } \\
\text { Oxímetro YSI modelo } \\
5100\end{array}$ \\
\hline $\mathrm{DQO}(\mathrm{mg} / \mathrm{L})$ & $\begin{array}{l}\text { Método convencional de oxidação química } \\
\text { com dicromato de potássio catalisada pela } \mathrm{Hg} \\
\text { em refluxo aberto. Titulação do excesso de } \\
\text { dicromato com sulfato ferroso amoniaca }\end{array}$ & $\begin{array}{l}\text { Digestor SOXLEHT } \\
\text { Nova Ética } \\
\text { Bureta } \\
\text { Vidrarias }\end{array}$ \\
\hline $\mathrm{pH}$ & Método potenciométrico com eletrodo de $\mathrm{pH}$ & $\begin{array}{l}\text { pHmetro Orion mod } \\
720^{\mathrm{a}}\end{array}$ \\
\hline $\mathrm{OD}(\mathrm{mg} / \mathrm{L})$ & Método eletrométrico com eletrodo de OD & $\begin{array}{l}\text { Oxímetro YSI modelo } \\
\qquad 5100\end{array}$ \\
\hline SST, SSF, SSV & $\begin{array}{l}\text { SST: Filtração em filtro-membrana de fibra de } \\
\text { vidro de } 1,2 \mu \text { e secagem em estufa a } 104^{\circ} \mathrm{C} \text {. } \\
\text { SSF: Calcinação da membrana após filtração e } \\
\text { secagem em forno mufla a } 550-600^{\circ} \mathrm{C} \\
\text { SSV: determinado por diferença (cálculo) }\end{array}$ & $\begin{array}{l}\text { Balança analítica Metler } \\
\text { AE } 260 \text { Delta Range } \\
\text { Sistema de filtração } \\
\text { Etufa } \\
\text { Mufla }\end{array}$ \\
\hline $\begin{array}{l}\text { Nitrogênio Total Kjeldhal } \\
\text { (NTK) }\end{array}$ & $\begin{array}{l}\text { Digestão química do nitrogênio orgânico, } \\
\text { destilação da amônia e titulação com } \mathrm{H}_{2} \mathrm{SO}_{4}\end{array}$ & Digestor Büchi \\
\hline Nitrogênio Amoniacal & Destilação da amônia e titulação com $\mathrm{H}_{2} \mathrm{SO}_{4}$. & Destilador Büchi \\
\hline Nitrato & $\begin{array}{c}\text { Eletrodo de íon-específico que responde a } \\
\text { atividade iônica do Nitrato numa faixa de } 0,14 \\
\text { a } 1400 \mathrm{mgN}-\mathrm{NO}_{3}{ }^{-} / \mathrm{L}\end{array}$ & $\begin{array}{l}\text { Eletrodo íon específico } \\
\text { Orion mod } 720 \mathrm{~A}\end{array}$ \\
\hline
\end{tabular}


Tabela 4.2 - Métodos analíticos e material utilizado para determinação dos parâmetros (conclusão)

\begin{tabular}{ccc}
\hline Parâmetros & Metodologia & $\begin{array}{c}\text { Equipamentosl } \\
\text { Infra-estrutura }\end{array}$ \\
\hline Fósforo Total & $\begin{array}{c}\text { Digestão ácida de fosfatos orgânicos e } \\
\text { colorimetria (Método do Ácido ascórbico) }\end{array}$ & $\begin{array}{c}\text { Digestor Büchi + } \\
\text { espectrofotômetro }\end{array}$ \\
Fósforo solúvel & $\begin{array}{c}\text { Colorimetria com reagente combinado (Método } \\
\text { do Ácido Ascórbico) }\end{array}$ & $\begin{array}{c}\text { Digestor Büchi + } \\
\text { espectrofotômetro }\end{array}$ \\
Alcalinidade & Titulação potenciométrica de neutralização & Bureta volumétrica \\
\hline
\end{tabular}

Os dados obtidos pelas análises realizadas nas amostras de esgoto bruto, lodo do tanque de aeração, efluente final da ETE e do lodo da ETA durante todo o período experimental, foram organizados e trabalhados matematicamente $\mathrm{e}$ estatisticamente em planilhas digitais, mais especificamente, utilizando o programa computacional MS-Excel. Foi utilizada a estatística descritiva como, média, mediana, quartil, mínimo, máximo, variância e desvio padrão. Foram utilizadas representações gráficas desses resultados através de séries temporais e "box-plot".

Para comparação dos resultados foi considerado que a amostra retirada durante a realização desta pesquisa na situação antes do lançamento do lodo da ETA no sistema de esgotos ou na situação após o lançamento do lodo da ETA no sistema de esgotos represente uma das quaisquer outras amostras, das duas situações, que poderiam ter sido retiradas no momento da coleta do material a ser analisado (MAGALHÃES, 2005).

Portanto, com base no "Teorema do Limite Central" usou-se intervalos de confiança, a 95\%, construídos com o respectivo erro-padrão: $s(\bar{X})=\frac{s}{\sqrt{n}}$.

A expressão matemática utilizada para determinar o Intervalo de Confiança foi:

$$
I C_{(\alpha / 2)}=\bar{X} \pm 1.96 \frac{s}{\sqrt{n}}
$$

$\bar{X}=$ média da amostra

$s$ = desvio padrão da amostra 
$n=$ tamanho da amostra

$\frac{s}{\sqrt{n}}=$ erro padrão, correspondendo ao desvio padrão da "Distribuição de Médias Amostrais"

1,96 = valor de $z$, na Distribuição Normal de Probabilidade, aceitando o erro de 0,05.

Os resultados foram analisados de forma comparativa entre os dados experimentais obtidos do esgoto bruto sobre os parâmetros $\mathrm{DBO}_{5}, \mathrm{DQO}$, concentrações SST, SSV e SSF, pH, alcalinidade, fósforo total e fósforo solúvel, série nitrogenada antes e depois do lançamento dos lodos da estação de tratamento de água no sistema de esgotos.

Foram analisados, também de forma comparativa os resultados das análises do lodo ativado do reator biológico antes e depois do lançamento do lodo da ETA nesse sistema, considerando os seguintes parâmetros: série de sólidos em suspensão, pH, OD e a razão SSVISST.

Ainda a mesma linha de análise foi feita sobre os resultados obtidos com 0 efluente final da ETE, dos parâmetros SST, SSV, SSF, pH, alcalinidade, DBO, DQO, série nitrogenada, fósforo total e fósforo solúvel. 


\section{5- Resultados e discussão}

\section{1- Considerações iniciais}

Existiram três etapas que geraram os resultados deste trabalho, sendo a primeira etapa de reconhecimento e adequação dos sistemas de água e esgotos a fim de possibilitar o desenvolvimento das duas etapas seguintes. A segunda etapa foi a de caracterização dos parâmetros estabelecidos como relevantes para esta pesquisa, tanto no sistema de tratamento de água, quanto no sistema de tratamento de esgotos considerando que os resíduos gerados na estação de tratamento de água são lançados na galeria de águas pluviais, conseqüentemente a estação de tratamento de esgotos recebe apenas os efluentes provenientes da rede coletora de esgotos à ela interligada. E a terceira etapa desta pesquisa foi a de caracterização dos parâmetros referentes ao sistema de tratamento de esgotos após ter sido efetuado a manobra na estação de tratamento de água que promoveu o lançamento dos seus resíduos na rede coletora de esgotos e não mais na galeria de águas pluviais como ocorria anteriormente.

A primeira etapa, descrita no parágrafo anterior, porém, não deve ser considerada como fonte de dados confiáveis para elaboração de análises comparativas e estatísticas referente ao tratamento de esgotos proposto neste projeto. Tal etapa caracterizou-se pelas atividades de ajuste dos sistemas de água e esgotos para que estes trabalhassem na rotina proposta por este projeto de pesquisa

\section{2- Caracterização do lodo gerado na estação de tratamento de água}

Foram levantados os dados de operação da ETA Juquitiba -SP no período de pesquisa compreendido entre 24 de maio e 15 de novembro de 2006, os quais foram fornecidos pela SABESP e estão apresentados na Tabela 5.1, com exceção dos dados de turbidez da água bruta que foram adaptados da descrição do Relatório Interno da SABESP (2003), e da vazão das descargas rápidas diárias de fundo dos decantadores, que foi calculada "in loco". 
Tabela 5.1 -Dados de operação da ETA Juquitiba no período de 2 de agosto à 15 de novembro de 2006.

\begin{tabular}{|c|c|}
\hline $\begin{array}{l}\text { Vazão media de água tratada } \\
\qquad\left(\mathrm{m}^{3} / \mathrm{dia}\right)\end{array}$ & 1.975 \\
\hline $\begin{array}{l}\text { Consumo médio diário de sulfato de alumínio } \\
\qquad(\mathrm{Kg} / \mathrm{dia})\end{array}$ & 48 \\
\hline $\begin{array}{l}\text { Turbidez média da água bruta } \\
\text { (UNT) }\end{array}$ & 10 \\
\hline $\begin{array}{l}\text { Vazão de água de lavagem dos filtros } \\
\qquad\left(\mathrm{m}^{3} / \mathrm{dia}\right)\end{array}$ & 46 \\
\hline $\begin{array}{l}\text { Vazão de água das descargas diárias } \\
\text { de fundo dos decantadores } \\
\left.\text { ( } \mathrm{m}^{3} / \mathrm{dia}\right)\end{array}$ & 11,16 \\
\hline $\begin{array}{l}\text { Volume de água descartada na } \\
\text { limpeza completa dos decantadores } \\
\qquad\left(\mathrm{m}^{3}\right)\end{array}$ & 256 \\
\hline
\end{tabular}

Para a obtenção da massa de lodo produzido na estação de tratamento de água, utilizou-se a equação descrita por Ferreira Filho e Alem Sobrinho, 2005:

$$
P L=Q \cdot(4,89 \cdot D A L+S S+C A P+A O) \cdot 10^{-3}
$$

onde:

$\mathrm{PL}=$ produção de lodo seco em $\mathrm{kg} / \mathrm{dia}$,

$\mathrm{Q}=$ vazão de água bruta $\mathrm{em} \mathrm{m}^{3} / \mathrm{dia}$,

$\mathrm{DAl}=$ dosagem de sais de alumínio, expresso como Al em mg/L,

SS = concentração de sólidos em suspensão totais na água bruta em $\mathrm{mg} / \mathrm{L}$,

$\mathrm{CAP}=$ concentração de carvão ativado em pó em mg/L,

$\mathrm{OA}=$ outros aditivos em $\mathrm{mg} / \mathrm{L}$ (ex.: sílica ativada, polímeros, etc...).

dados obtidos:

Vazão de água bruta (média diária) $=1.975 \mathrm{~m}^{3} / \mathrm{dia}$

Dosagem de sais de alumínio, expressos como $\mathrm{Al}=3,84 \mathrm{mg} / \mathrm{L}$

$\mathrm{SS}=10 \mathrm{mg} / \mathrm{L}$

$\mathrm{CAP}=0$ (zero)

Outros aditivos $=0$ (zero) 
Portanto: $\quad P L=1.975 \mathrm{~m}^{3} \times(4,89 \times 3,84 \mathrm{mg} / \mathrm{L}+10 \mathrm{mg} / \mathrm{L}+0+0) \cdot 10^{-3}$

$$
\mathrm{PL}=56,84 \mathrm{Kg} / \mathrm{dia}
$$

Massa devido a retro-lavagem dos filtros:

$46 \mathrm{~m}^{3} /$ dia de água de lavagem (SABESP, 2006)

SST médio de $203 \mathrm{mg} / \mathrm{L}$ (tebela 5.5)

Portanto: PL.filtros $=9,34 \mathrm{Kg} / \mathrm{dia}$

Massa devido a limpeza dos decantadores:

$P L_{\text {.deant. }}=P L_{\text {.total }}-P L_{\text {.filtros }}$

PL.decant. $=56,84-9,34(\mathrm{Kg} / \mathrm{dia})$

$P L$.decant. $=47,50 \mathrm{Kg} / \mathrm{dia}$

Sendo esta última massa dividida em (1) descargas rápidas diárias de fundo dos decantadores e (2) lavagem mensal completa dos decantadores, então:

Massa devido a descarga diária rápida de fundo dos decantadores:

$11,16 \mathrm{~m}^{3} /$ dia de líquidos das descargas diárias de fundo dos decantadpores SST médio de $656 \mathrm{mg} / \mathrm{L}$ (Tabela 5.5)

Portanto: PL.desc rap decant. $=7,32 \mathrm{Kg} / \mathrm{dia}$

Com posse desses dados elaborou-se a Tabela 5.2.

Tabela 5.2 - Resumo dos dados de volumes, vazões e concentrações de sólidos em suspensão total obtidos da ETA Juquitiba

\begin{tabular}{|c|c|c|c|}
\hline Parâmetro & Vazões ( $\left.\mathrm{m}^{3} / \mathrm{dia}\right)$ & SST (mg/L) & $\begin{array}{c}\text { Massa de sólidos } \\
\text { (kg/dia) }\end{array}$ \\
\hline Água de lavagem de filtros & 46 & 203 & 9,34 \\
\hline $\begin{array}{l}\text { Água de descargas rápidas de } \\
\text { fundo dos decantadores }\end{array}$ & 11,16 & 656 & 7,32 \\
\hline Água de lavagem dos & 8,53 & 4710 & 40,18 * \\
\hline decantadores & ou $256 \mathrm{~m}^{3} / \mathrm{mês}$ & & ou $1.205,40 \mathrm{~kg} / \mathrm{mês}$ \\
\hline Totais & 65,69 & 865 & 56,84 \\
\hline
\end{tabular}

${ }^{*} 40,18 \mathrm{~kg} / \mathrm{dia}=47,50 \mathrm{~kg} / \mathrm{dia}-7,32 \mathrm{~kg} / \mathrm{dia}$ 
Analisando a Tabela 5.2, é possível verificar que, após o início do lançamento do lodo da ETA no sistema de esgotos, existe um acréscimo diário de $57,16 \mathrm{~m}^{3}$ de líquidos no sistema de esgotos sanitários devido aos filtros (46 $\mathrm{m}^{3} / \mathrm{dia}$ ) e às descargas rápidas de fundo dos decantadores $\left(11,16 \mathrm{~m}^{3} / \mathrm{dia}\right)$.

No entanto, foi difícil medir o volume que realmente entrou na rede coletora de esgoto pela lavagem completa dos decantadores da ETA. Ta fato se deve à perda por transbordamento através da calha vertedora do canal que encaminha estes líquidos até a rede coletora de esgotos.

Então adotou-se estimar o volume que entrou na ETE utilizarando os dados registrados pelo medidor de vazão de esgotos afluentes ali existente e sabendo-se os dias de lavagem dos decantadores, foi possível definir o volume aportado na ETE devido ao procedimento de lavagem dos decantadores da ETA.

As datas de lavagem dos decantadores com lançamento dos líquidos na ETE, dentro do período da pesquisa, foram 18 de agosto, 17 de setembro e 18 de outubro de 2006, tendo sido registrado pelo equipamento de medição de vazões/volumes da ETE apenas o volume do dia 18 de agosto.

Os demais dias não foram registrados por motivo de falha do equipamento. Foi então considerado apenas um dia de informação, 18 de agosto de 2006, para verificação do volume aportado na ETE devido este procedimento.

Tabela 5.3 - Resumo das vazões de entrada de esgotos na ETE Juquitiba

\begin{tabular}{ccc}
\hline Parâmetro & $\begin{array}{c}\text { Período sem lodo } \\
\text { de ETA na ETE } \\
\text { Vazão média (m³/dia) }\end{array}$ & $\begin{array}{c}\text { Período com lodo } \\
\text { de ETA na ETE }\end{array}$ \\
\hline
\end{tabular}

Tendo sido registrado, nesta data, a entrada de um volume de $706 \mathrm{~m}^{3}$ e a média do período ter sido $431 \mathrm{~m}^{3}$, como mostra a Tabela 5.3, encontrou-se uma diferença de $275 \mathrm{~m}^{3}$. Como havia sido previsto um acréscimo de $256 \mathrm{~m}^{3}$ na ETE para as datas de lavagem dos decantadores, verificou-se uma forte coerência e assim, poder admitir que as perdas pela calha vertedora, existente na ETA, são insignificantes. 
Verificou-se, também através dos dados da Tabela 5.3, que existiu um acréscimo médio de $84 \mathrm{~m}^{3} /$ dia após o início da operação de lançamento de lodo de ETA no sistema de esgotos, maior que aquele calculado anteriormente, de 65,69 $\mathrm{m}^{3}$, devido às operações na ETA. Porém é importante ressalvar que, parte desse acréscimo, pode ter sido devido algumas chuvas ocorridas no segundo do período descrito, uma vez que este coincide com o "início das águas". Não foi realizado o controle de chuvas nesta pesquisa e, com isso, adotou-se por a não discussão das vazões de infiltração de água de chuva na rede coletora de esgotos.

A Tabela 5.4 apresenta a aplicação do resíduo sólido gerado pela estação de tratamento de água no sistema de tratamento de esgotos, considerando que todo resíduo produzido na ETA foi encaminhado à ETE, via rede coletora de esgotos.

Tabela 5.4 - Resumo da aplicação do lodo da ETA na ETE - Juquitiba

\begin{tabular}{ccc}
\hline Origem do resíduo & $\begin{array}{c}\text { Massa de sólidos } \\
\mathrm{Kg} / \text { dia }\end{array}$ & $\begin{array}{c}\text { Aplicação do lodo da ETA na ETE } \\
\text { (mg de resíduo sólido da ETA / litro de esgotos) }\end{array}$ \\
\hline Lavagem de filtros & 9,34 & 21,67 \\
desc. Rap. Fundo dos decant. & 7,32 & 16,98 \\
Lavagem dos decantadores & 40,18 & 93,22 \\
Total & 56,84 & 131,87 \\
\hline
\end{tabular}

Sendo a ETA quatro vezes maior que a ETE no que diz respeito às vazões ou seja, a ETA produz aproximadamente $2.000 \mathrm{~m}^{3}$ de água tratada por dia, como média anual, e considerando que $80 \%$ desta água se transforme em esgotos, a bacia atendida por esta ETA produz $1.600 \mathrm{~m}^{3}$ de esgotos por dia. Portanto apesar de a ETE receber seus efluentes de uma bacia abastecida por água daquela ETA, a ETE recebe apenas a ordem de $400 \mathrm{~m}^{3}$ de esgotos por dia de média anual. Desta maneira, a condição de aplicação dos resíduos gerados na estação de tratamento de água no sistema de esgotos foi de quatro ETA's para uma ETE.

Porém, é importante destacar que a aplicação do resíduo devido à lavagem dos decantadores não foi realizada como descrito na Tabela 5.4, de forma distribuída ao longo do mês, e sim de forma pontual, em até quatro horas de um único dia.

Aplicou-se $256 \mathrm{~m}^{3}$ de águas de resíduos dos decantadores, à uma concentração de sólidos em suspensão totais de 4.710 mg/L em 4 horas, ou, ainda, $1.205,40 \mathrm{~kg}$ de resíduo sólido por procedimento, como descrito na Tabela 5.2. 
Assim, a aplicação do resíduos da lavagem dos decantadores no sistema de esgotos acontece em um único dia à uma taxa descrita na Figura 5.1, considerando uma aplicação ao longo de todo um dia, uma vez que o controle das vazões de esgotos na ETE foi realizada com grandeza diária.

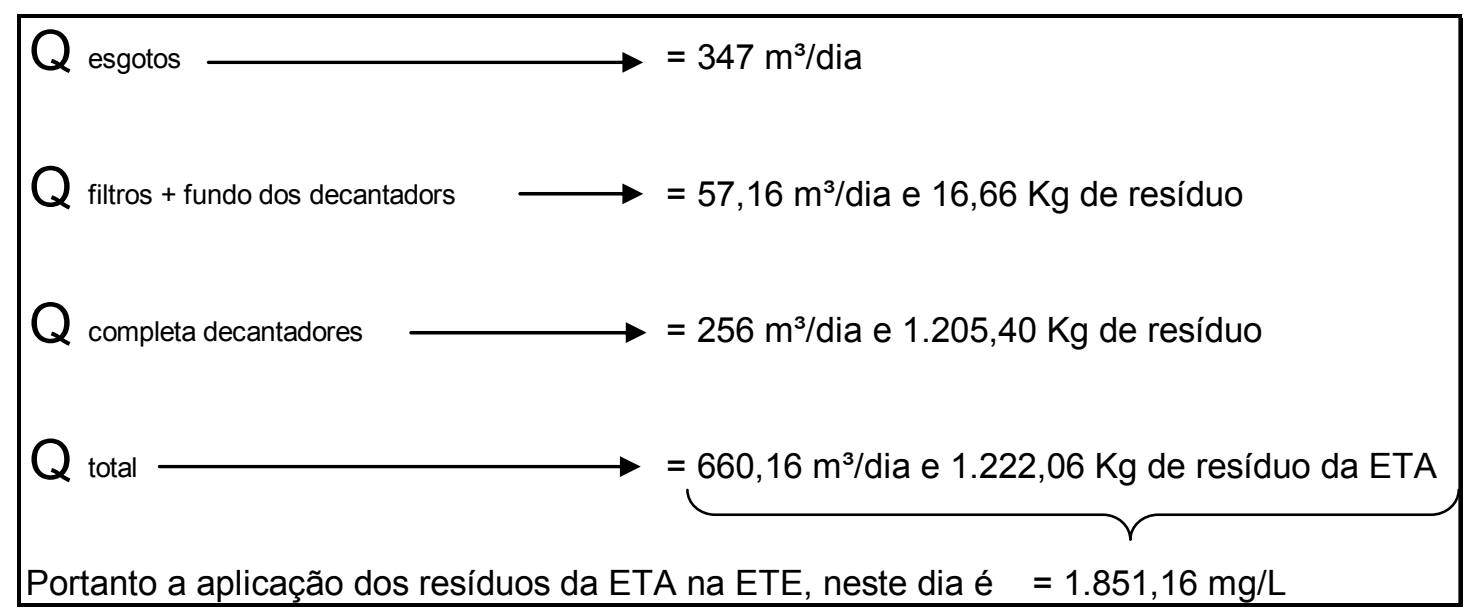

Figura 5.1 - Esquema de cálculo da aplicação dos resíduos da ETA na ETE, no dia da lavagem dos decantadores da ETA.

Outros dados foram levantados referentes aos resíduos gerados na estação de tratamento de água, como descritos na Tabela 5.5.

Tabela 5.5 - Resultados médios dos parâmetros medidos nos resíduos da ETA - Juquitiba

\begin{tabular}{cccc}
\hline Parâmetros & $\begin{array}{c}\text { Resíduos de lavagem } \\
\text { dos filtros }\end{array}$ & $\begin{array}{c}\text { Resíduos de lavagem } \\
\text { dos decantadores } \\
\text { descargas rápidas } \\
\text { diárias }\end{array}$ & $\begin{array}{c}\text { Resíduos de lavagem } \\
\text { dos decantadores }\end{array}$ \\
\hline DQO (mg//l) & 59 & 164 & 1067 \\
SST (mg/L) & 203 & 656 & 4229 \\
SSF (mg/L) & 137 & 466 & 3330 \\
SSV (mg/L) & 66 & 190 & 1150 \\
Fósforo total (mg/L) & 0,2 & 0,8 & 4,8 \\
Nitrogênio total (mg/L) & 2,1 & 5,6 & 42,3 \\
PH & 5,8 & 5,7 & 5,8 \\
Alcalinidade (mg/L) & - & - & 46 \\
SSV/SST & 0,33 & 0,29 & 0,27 \\
\hline
\end{tabular}


As amostras dos resíduos de lavagem dos decantadores foram coletadas de forma aleatória no canal de saída destes líquidos da ETA, devido à impossibilidade de se realizar uma amostragem composta.

Foi verificado uma faixa típica de lodo de estação de tratamento de água para a relação SSVISST próximo de 0,30 , condizente com lodos de estações com captação de águas superficiais.

O Quadro 5.1 contém os resultados das análises da fase líquida do lodo da ETA pela técnica analítica ICP-OES/AA e dos compostos deste lodo pela técnica analítica Espectrometria de Fluorescência de Raios-X (WDXRF), com nível de confiança de 95\%. Ambas realizadas no IPEN / CQMA.

Quadro 5.1 - Resultados das análises da fase líquida do lodo da ETA, amostra 986 composta do lodo dos filtros e decantadores, pela técnica analítica ICP-OESIAA e dos compostos deste lodo pela técnica analítica Espectrometria de Fluorescência de Raios-X (WDXRF)

\begin{tabular}{|c|c|c|c|c|c|}
\hline Elemento & $\begin{array}{c}\text { Concentração } \\
\mu \mathrm{g} / \mathrm{mL}\end{array}$ & Elemento & $\begin{array}{c}\text { Concentração } \\
\mu \mathrm{g} / \mathrm{mL}\end{array}$ & Elem./Comp. & $\%$ \\
\hline$B$ & $<0,004$ & $P$ & $0,023 \pm 0,003$ & $\overline{\mathrm{Al}_{2} \mathrm{O}_{3}}$ & $34,8 \pm 0,5$ \\
\hline $\mathrm{Al}$ & $0,025 \pm 0,003$ & $\mathrm{Ca}$ & $1,64 \pm 0,01$ & $\mathrm{Fe}_{2} \mathrm{O}_{3}$ & $31,2 \pm 0,5$ \\
\hline $\mathrm{V}$ & $<0,03$ & $\mathrm{Fe}$ & $0,020 \pm 0,004$ & $\mathrm{SiO}_{2}$ & $28,3 \pm 0,5$ \\
\hline $\mathrm{Cr}$ & $<0,01$ & $\mathrm{Ba}$ & $0,017 \pm 0,001$ & $\mathrm{~K}_{2} \mathrm{O}$ & $1,7 \pm 0,3$ \\
\hline $\mathrm{Mn}$ & $0,355 \pm 0,003$ & Co & $<0,01$ & $\mathrm{MnO}$ & $1,0 \pm 0,2$ \\
\hline $\mathrm{Ni}$ & $<0,01$ & & & $\mathrm{TiO}_{2}$ & $0,71 \pm 0,05$ \\
\hline $\mathrm{Cu}$ & $<0,02$ & & & $\mathrm{SO}_{3}$ & $0,70 \pm 0,08$ \\
\hline $\mathrm{Zn}$ & $<0,001$ & & & $\mathrm{P}_{2} \mathrm{O}_{5}$ & $0,57 \pm 0,08$ \\
\hline Mo & $<0,01$ & & & $\mathrm{Cl}$ & $0,32 \pm 0,08$ \\
\hline Sn & $<0,06$ & & & $\mathrm{MgO}$ & $0,22 \pm 0,08$ \\
\hline $\mathrm{Li}$ & $0,003 \pm 0,0001$ & & & $\mathrm{CaO}$ & $0,17 \pm 0,05$ \\
\hline $\mathrm{Sb}$ & $<0,001$ & & & Elem./Comp. & $\mathrm{mg} / \mathrm{kg}$ \\
\hline $\mathrm{Be}$ & $<0,002$ & & & $\mathrm{Na}_{2} \mathrm{O}$ & $857 \pm 20$ \\
\hline $\mathrm{Mg}$ & $0,640 \pm 0,002$ & & & $\mathrm{Br}$ & $416 \pm 20$ \\
\hline As & $<0,001$ & & & $\mathrm{Cr}_{2} \mathrm{O}_{3}$ & $244 \pm 20$ \\
\hline $\mathrm{Na}$ & $1,57 \pm 0,01$ & & & $\mathrm{ZnO}$ & $177 \pm 10$ \\
\hline $\mathrm{Si}$ & $2,93 \pm 0,01$ & & & $\mathrm{NiO}$ & $154 \pm 10$ \\
\hline K & $0,493 \pm 0,001$ & & & $\mathrm{CuO}$ & $128 \pm 10$ \\
\hline $\mathrm{Ag}$ & $<0,002$ & & & $\mathrm{As}_{2} \mathrm{O}_{3}$ & $110 \pm 30$ \\
\hline $\mathrm{Cd}$ & $<0,0001$ & & & $\mathrm{ZrO}_{2}$ & $43 \pm 10$ \\
\hline $\mathrm{Pb}$ & $<0,001$ & & & $\mathrm{Rb}_{2} \mathrm{O}$ & $41 \pm 10$ \\
\hline
\end{tabular}


A amostra 986, foi coletada no dia 9 de agosto de 2006, sendo uma amostra composta do lodo da lavagem dos filtros e do lodo das descargas rápidas de fundo dos decantadores. Foram analisados os parâmetros listados na Figura 5.2 pelo IPEM e, no laboratório de saneamento da EP-USP, analisados os sólidos em suspensão totais: SST $=1.024 \mathrm{mg} / \mathrm{L}$, fixos: $\mathrm{SSF}=744 \mathrm{mg} / \mathrm{L}$ e voláteis: $\mathrm{SSV}=280$ $\mathrm{mg} / \mathrm{L}$.

\subsubsection{Resultados do ensaio de Jar-Test}

O ensaio de Jar-Test realizado conforme descrito na Tabela 4.1 apresentou os seguintes resultados de concentrações de fósforo total:

$\begin{array}{ll}\text { - J_1 (branco) } & 5,7 \mathrm{mg} \cdot P / \mathrm{L} \\ \text { - J_2 (25mg/L) } & 5,1 \mathrm{mg} \cdot P / \mathrm{L} \\ \text { - J_3 (50mg/L) } & 5,0 \mathrm{mg} \cdot \mathrm{P} / \mathrm{L} \\ \text { - J_4 (75mg/L) } & 4,7 \mathrm{mg} \cdot \mathrm{P} / \mathrm{L} \\ \text { - J_5 (100mg/L) } & 4,6 \mathrm{mg} \cdot P / \mathrm{L} \\ \text { - J_6 (150mg/L) } & 4,1 \mathrm{mg} \cdot P / \mathrm{L}\end{array}$

Verificou-se com este ensaio que a aplicação de lodo de ETA no esgoto bruto de $25 \mathrm{mg} / \mathrm{L}, 50 \mathrm{mg} / \mathrm{L}, 75 \mathrm{mg} / \mathrm{L}, 100 \mathrm{mg} / \mathrm{L}$ e $150 \mathrm{mg} / \mathrm{L}$, seguido de agitação e sedimentação promoveu a diminuição da concentração de fósforo total de $10 \%$, $12 \%, 17 \%, 19 \%$ e $28 \%$ respectivamente. 


\section{3- Caracterização dos esgotos bruto, tratado e do lodo do reator biológico da ETE, anteriormente ao início do lançamento do lodo da ETA no sistema de esgotos}

O período de identificação dos parâmetros referidos na metodologia da estação de tratamento de esgotos, antes do início do lançamento do lodo da ETA no sistema de esgotos, está compreendido entre 24 de maio e 26 de julho de 2006 . Trata-se do período em que a estação trabalhou em regime uniforme de operação com o controle da idade do lodo de 25 dias.

A estação de tratamento de esgotos de Juquitiba recebe os efluentes de uma parcela daquela população atendida pela ETA, do mesmo município, portanto apresenta vazões inferiores à desta última estação, como apresentado na Tabela 5.6.

Tabela 5.6 - Vazão de esgoto afluente à ETE Juquitiba no período de 24 de maio à 26 de julho de 2006

Vazão $\left(\mathrm{m}^{3} / \mathrm{dia}\right)$

Período: 24/05/06 à 26/07/06

\begin{tabular}{cc}
\hline Número de dados & 59 \\
Média & 346 \\
Desvio padrão & 52 \\
Mínimo & 259 \\
Máximo & 521 \\
Intervalo de confiança (95\%) & {$[332 ; 359]$} \\
\hline
\end{tabular}

O período em que foram registrados os dados de vazões da ETE, nesta segunda etapa da pesquisa coincide com o período climático estiagem, ou seja, de seca. Realmente ocorreram poucas chuvas entre estas datas, porém não foi feito controle sobre esta grandeza, apenas anotações no caderno de campo sendo: dia ensolarado, dia chuvoso, etc.

Verificaram-se vazões bem definidas ao longo deste período, como descrito na Tabela 5.6, com dois conjuntos de datas que sobressaíram à média sendo, o primeiro logo no início do período, dias 24 e 25 de maio com vazões de 456 e 484 $\mathrm{m}^{3} /$ dia e, o segundo conjunto de datas no mês de junho entre os dias 12 e 13, com vazões de 521 e $392 \mathrm{~m}^{3} /$ dia. 
Os resultados referentes ao lodo dos reatores biológicos e ao efluente tratado da estação de tratamento de esgotos serão apresentados sempre com as indicações R.1 e R.2, devido à estação ser constituída por dois reatores, o reator 1 e o reator 2 , que trabalham com seus lodos separadamente. Estes lodos nunca se misturam em condições normais de operação. Conseqüentemente seus efluentes possuem características individuais. Isto é uma característica do processo de lodo ativado com reatores seqüenciais em bateladas.

Tabela 5.7 - Resultados dos parâmetros $\mathrm{DBO}_{5,20}$ e DQO do esgoto afluente e tratado da ETE Juquitiba, sem o lançamento do lodo da ETA no sistema de esgotos

\begin{tabular}{ccccccc}
\hline Parâmetro & Ponto & $\mathrm{n}$ & Média & $\begin{array}{c}\text { Desvio } \\
\text { padrão }\end{array}$ & $\begin{array}{c}\text { Erro } \\
\text { padrão }\end{array}$ & $\begin{array}{c}\text { Intervalo de } \\
\text { confiança }(95 \%)\end{array}$ \\
\hline $\mathrm{DBO}_{5,20}(\mathrm{mg} / \mathrm{L})$ & Afluente & 9 & 369 & 100 & 33,33 & {$[303 ; 434]$} \\
& Efluente R.1 & 5 & 33 & 17 & 7,60 & {$[18,09 ; 47,90]$} \\
& Efluente R.2 & 8 & 58 & 31 & 2,82 & {$[52,45 ; 63,54]$} \\
DQO $(\mathrm{mg} / \mathrm{L})$ & Afluente & 10 & 718 & 134 & 42,37 & {$[634 ; 801]$} \\
& Efluente R.1 & 5 & 55 & 33 & 2,24 & {$[50,61 ; 59,38]$} \\
& Efluente R.2 & 9 & 94 & 46 & 15,33 & {$[63,95 ; 124,05]$} \\
\hline
\end{tabular}

Na Tabela 5.7 verifica-se que o esgoto afluente à estação de tratamento de esgotos tem características tipicamente domésticos e, no que se refere ao efluente da estação, verifica-se resultados típicos do processo de lodo ativado.

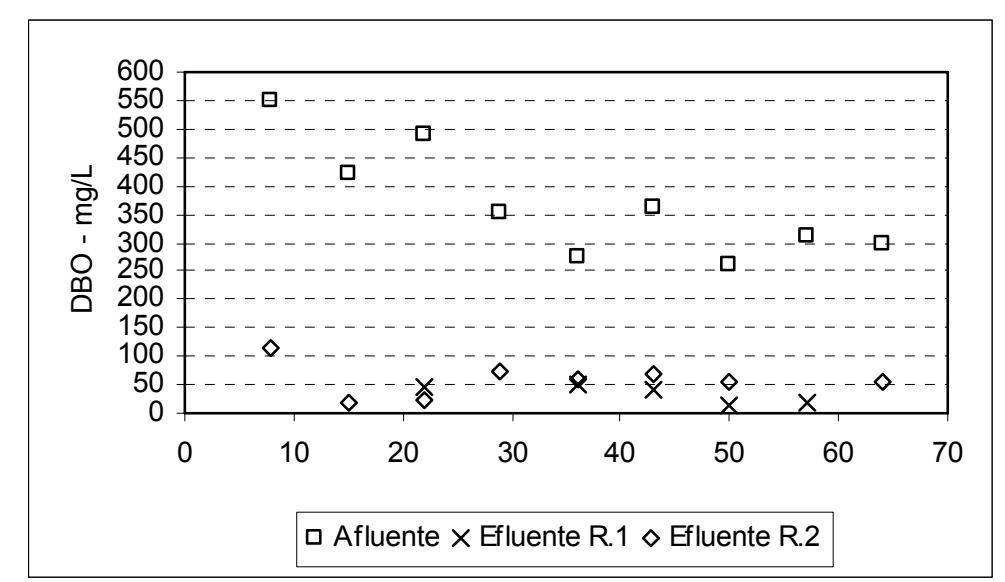

Figura 5.3 - Séries temporais de $\mathrm{DBO}_{5,20}$ do esgoto afluente e efluente da ETE Juquitiba, sem o lançamento do lodo da ETA no sistema de esgotos 


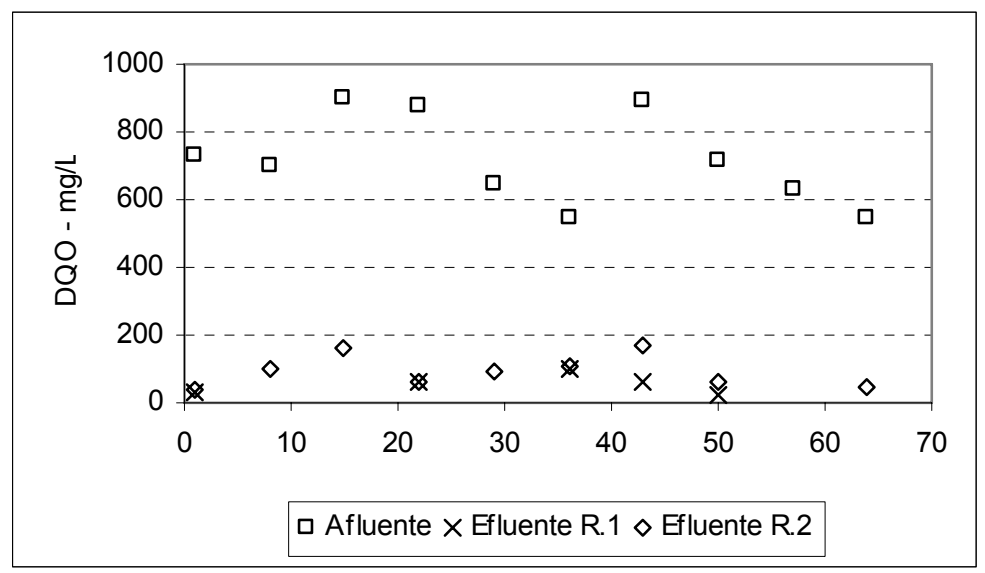

Figura 5.4 - Séries temporais de DQO do esgoto afluente e efluente da ETE Juquitiba, sem o lançamento do lodo da ETA no sistema de esgotos

Os resultados referentes ao afluente à ETE, nos diagramas de séries temporais de $\mathrm{DBO}_{5,20}$ e DQO, das Figuras 5.3 e 5.4, que ilustram a Tabela 5.7, possibilitam verificar que estes parâmetros apresentam características de esgotos domésticos “médio", segundo Jordão e Pessoa (2005). Típicos de épocas secas.

Tabela 5.8 - Resultados dos parâmetros sólidos em suspensão totais, voláteis e fixos do esgoto afluente, tratado e do lodo dos reatores biológicos da ETE Juquitiba, sem o lançamento do lodo da ETA no sistema de esgotos

\begin{tabular}{ccccccc}
\hline Parâmetro & Ponto & $\mathrm{n}$ & Média & $\begin{array}{c}\text { Desvio } \\
\text { padrão }\end{array}$ & $\begin{array}{c}\text { Erro } \\
\text { padrão }\end{array}$ & $\begin{array}{c}\text { Intervalo de } \\
\text { confiança }(95 \%)\end{array}$ \\
\hline SST $(\mathrm{mg} / \mathrm{L})$ & Afluente & 9 & 325 & 75,28 & 25,09 & {$[275 ; 374]$} \\
& Lodo R.1 & 9 & 2.603 & 451,68 & 150,56 & {$[2307 ; 2.897]$} \\
& Lodo R.2 & 6 & 2.848 & 283,77 & 115,85 & {$[2620 ; 3.075]$} \\
& Efluente R.1 & 6 & 36 & 12,56 & 5,13 & {$[25,95 ; 46,05]$} \\
& Efluente R.2 & 9 & 45 & 21,98 & 7,33 & {$[30,53 ; 59,25]$} \\
SSV $(\mathrm{mg} / \mathrm{L})$ & Afluente & 9 & 264 & 53,22 & 17,74 & {$[229 ; 298]$} \\
& Lodo R.1 & 9 & 1.762 & 203,67 & 67,89 & {$[1629 ; 1.895]$} \\
& Lodo R.2 & 6 & 2.096 & 112,85 & 46,07 & {$[2005 ; 2.186]$} \\
& Efluente R.1 & 6 & 29 & 27,44 & 11,20 & {$[7,38 ; 51,29]$} \\
& Efluente R.2 & 9 & 40 & 18,81 & 6,27 & {$[27,27 ; 51,84]$} \\
& Afluente & 9 & 61 & 32,48 & 10,83 & {$[39,67 ; 82,11]$} \\
SSF $(\mathrm{mg} / \mathrm{L})$ & Lodo R.1 & 9 & 840 & 309,58 & 103,19 & {$[638 ; 1.042]$} \\
& Lodo R.2 & 6 & 752 & 211,02 & 86,15 & {$[583 ; 920]$} \\
& Efluente R.1 & 3 & 8 & 5,66 & 3,27 & {$[1,60 ; 14,40]$} \\
& Efluente R.2 & 5 & 10 & 6,07 & 2,71 & {$[4,28 ; 14,92]$} \\
\hline
\end{tabular}


A partir da Tabela 5.8, verificou-se as relações SSVISST do lodo dos reatores biológicos 1 e 2, sendo 0,68 e 0,73, respectivamente e, ainda, a mesma relação em 0,81 para o esgoto bruto.

Fazendo uma análise com as Tabelas 5.6, 5.7 e 5.8, e sabendo-se o volume dos reatores quando cheios $\left(900 \mathrm{~m}^{3}\right)$, verificou-se a relação alimento/microrganismo (A/M) considerando a média das concentrações de sólidos em suspensão voláteis dos dois reatores. Sendo $\mathrm{A} / \mathrm{M}=0,074 \mathrm{Kg} \mathrm{DBO}{ }_{5,20} / \mathrm{Kg}$ SSVTA.dia, ou ainda, $\mathrm{A} / \mathrm{M}=$ 0,144 Kg DQO/Kg SSVTA.dia, características de sistemas de lodo ativado com aeração prolongada.

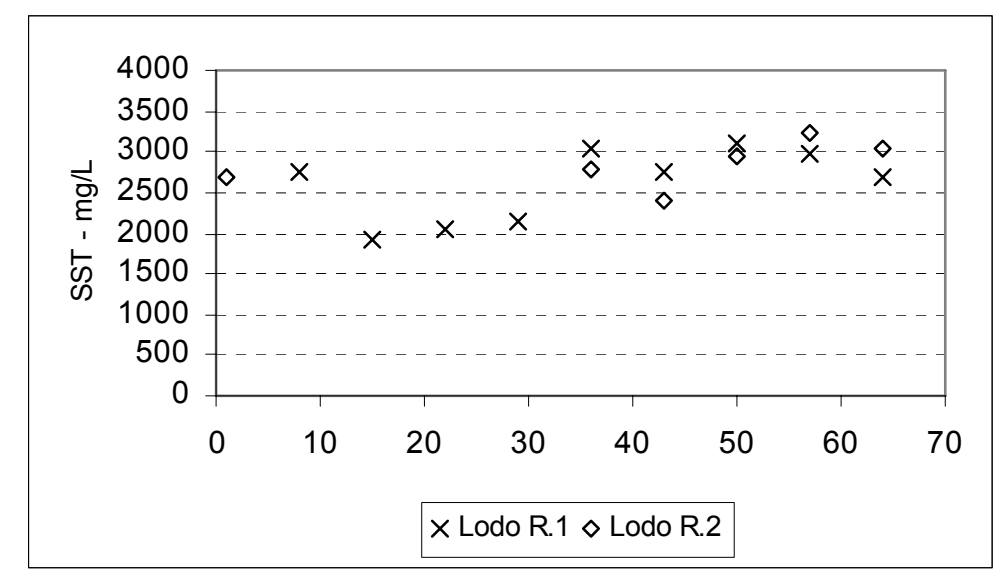

Figura 5.5 - Séries temporais de sólidos em suspensão totais do lodo dos reatores biológicos 1 e 2 da ETE Juquitiba, sem o lançamento do lodo da ETA no sistema de esgotos

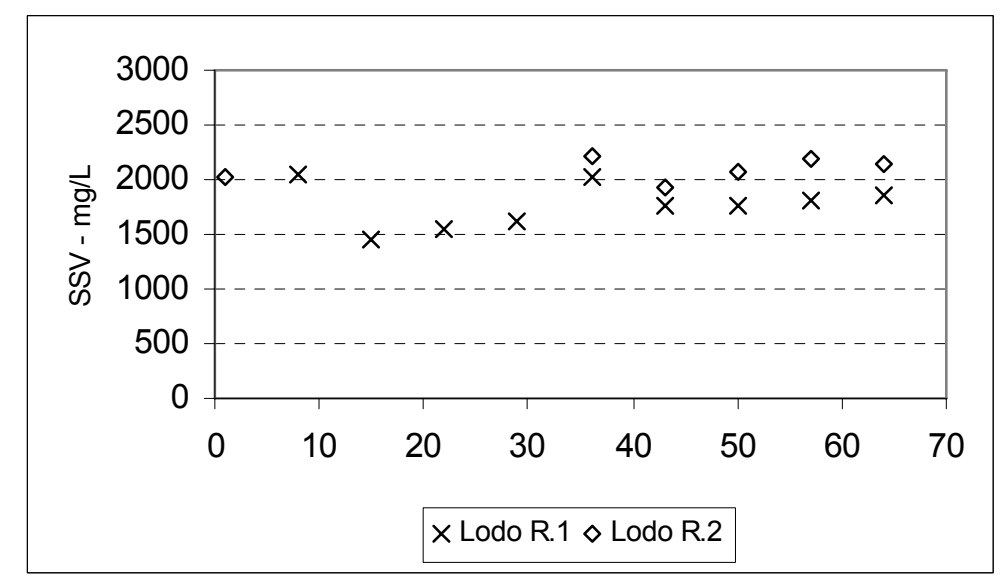

Figura 5.6 - Séries temporais de sólidos em suspensão voláteis do lodo dos reatores biológicos 1 e 2 da ETE Juquitiba, sem o lançamento do lodo da ETA no sistema de esgotos 


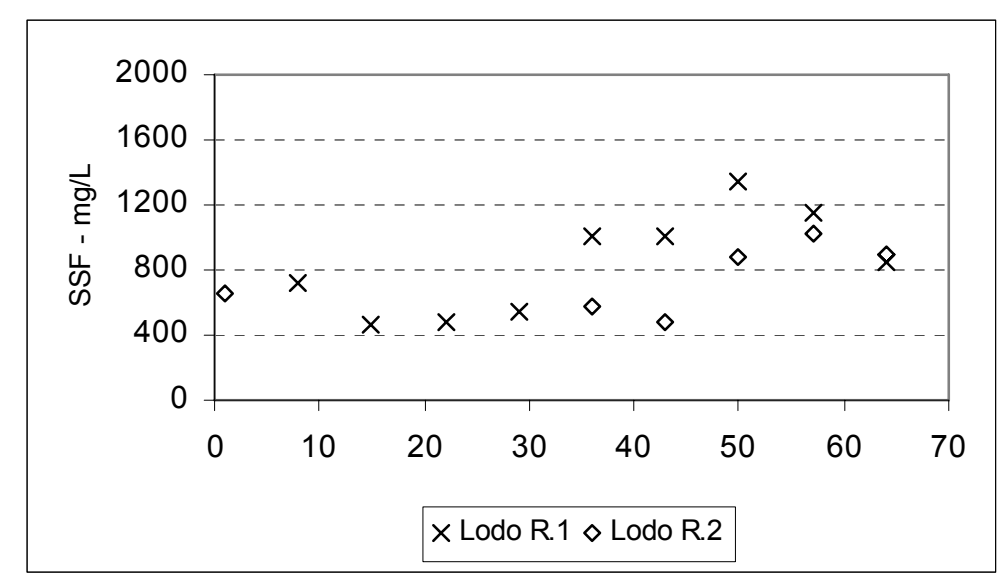

Figura 5.7 - Séries temporais de sólidos em suspensão fixos do lodo dos reatores biológicos 1 e 2 da ETE Juquitiba, sem o lançamento do lodo da ETA no sistema de esgotos

A produção de lodo pela estação pode ser calculada pelo produto da vazão de lodo de excesso pela concentração de sólidos deste lodo, somado a vazão de efluente tratado pela concentração de sólidos neste efluente. Com os dados de vazão da Tabela 5.6 e das concentrações de sólidos da Tabela 5.8, obteve-se a produção de lodo de excesso de $54,5 \mathrm{Kg} /$ dia.

Ns Figura 5.7 verificaou-se um acréscimo de sólidos fixos no reator 1, maior que aquele que ocorreu no reator 2 , entre os dias 30 e 60 deste período. Isto é uma das características do sistema com reatores seqüenciais em bateladas, onde hora os esgotos entram no reator 1 , hora no reator 2 , e nunca nos dois reatores ao mesmo tempo.

Tabela 5.9 - Resultados dos parâmetros NKT, nitrogênio amoniacal e nitrato do esgoto afluente e tratado da ETE Juquitiba, sem o lançamento do lodo da ETA no sistema de esgotos

\begin{tabular}{ccccccc}
\hline Parâmetro & Ponto & N & Média & $\begin{array}{c}\text { Desvio } \\
\text { padrão }\end{array}$ & $\begin{array}{c}\text { Erro } \\
\text { padrão }\end{array}$ & $\begin{array}{c}\text { Intervalo de } \\
\text { confiança }(95 \%)\end{array}$ \\
\hline NKT (mg/L) & Afluente & 10 & 77,45 & 15,93 & 5,04 & {$[67,57 ; 87,32]$} \\
& Efluente R.1 & 5 & 6,76 & 3,72 & 1,66 & {$[3,50 ; 10,01]$} \\
& Efluente R.2 & 5 & 9,40 & 1,75 & 0,78 & {$[7,86 ; 10,94]$} \\
N-Amoniacal (mg/L) & Afluente & 10 & 49,03 & 13,33 & 4,22 & {$[40,77 ; 57,29]$} \\
& Efluente R.1 & 10 & 3,08 & 3,51 & 1,11 & {$[0,91 ; 5,26]$} \\
& Efluente R.2 & 7 & 1,07 & 1,50 & 0,57 & {$[-0,04 ; 2,18]$} \\
Nitrato (mg/L) & Afluente & 4 & 0,32 & 0,22 & 0,11 & {$[0,11 ; 0,53]$} \\
& Efluente R.1 & 4 & 5,75 & 1,64 & 0,82 & {$[4,15 ; 7,35]$} \\
& Efluente R.2 & 5 & 5,07 & 2,43 & 1,09 & {$[2,94 ; 7,19]$} \\
\hline
\end{tabular}


Os resultados obtidos das análises da série nitrogenada descritas na Tabela 5.9 mostraram que o esgoto afluentes à ETE possui características bem típicas de esgotos domésticos. Já os efluentes são característicos dos efluentes de sistemas sem a previsão de remoção de nitrogênio, porém nota-se que a concentração de nitrato efluente é baixa em relação à quantidade de $\mathrm{N}$-amoniacal removido.

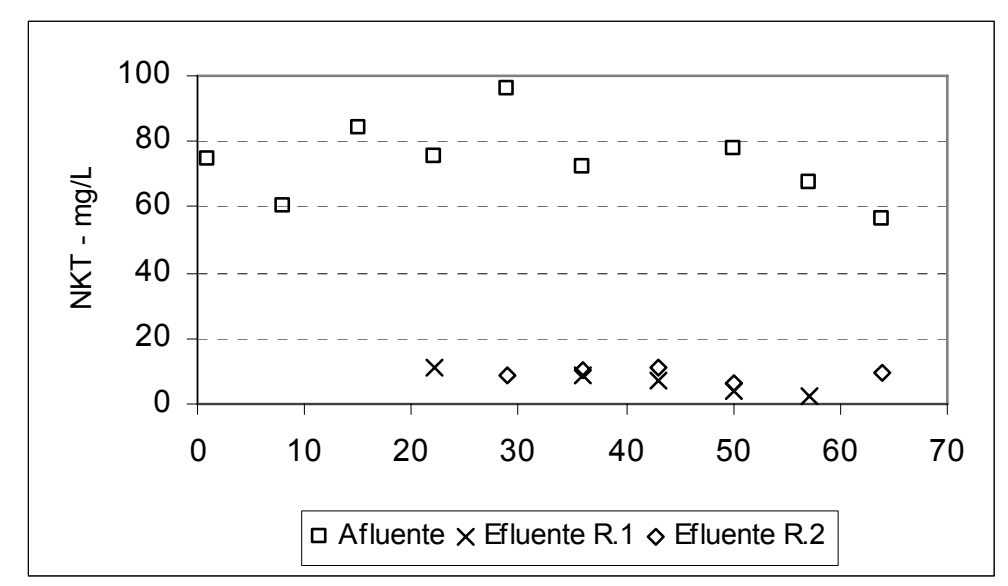

Figura 5.8 - Séries temporais de NKT do esgoto afluente e efluente da ETE Juquitiba, sem o lançamento do lodo da ETA no sistema de esgotos

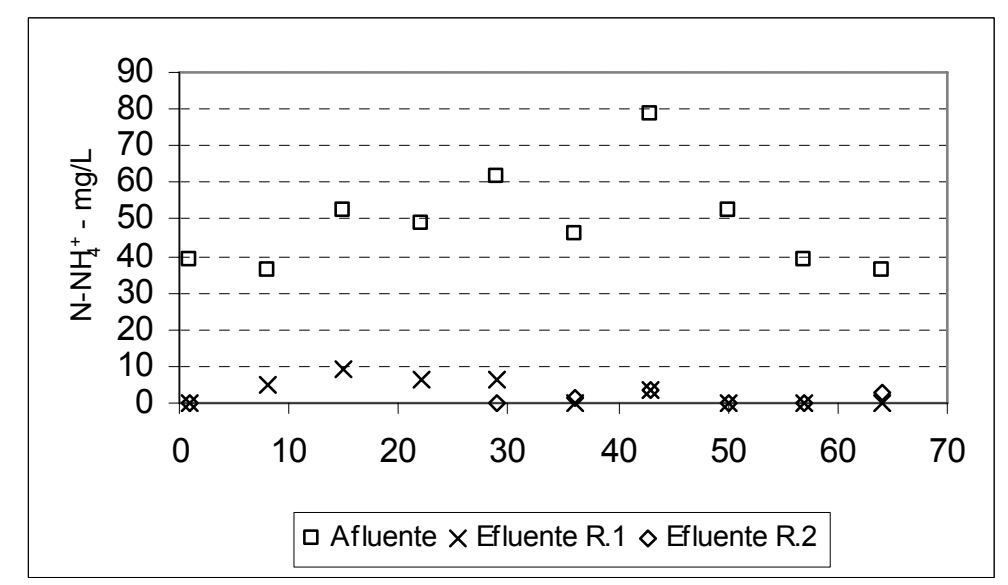

Figura 5.9 - Séries temporais de nitrogênio amoniacal do esgoto afluente e efluente da ETE Juquitiba, sem o lançamento do lodo da ETA no sistema de esgotos

As análises laboratoriais de nitrato tiveram seu encerramento no dia 21 de junho de 2006, devido à quebra do aparelho utilizado nesta medição (eletrodo), seguido da demora da reposição por um novo aparelho, por parte do fornecedor. No período em que foi medido este parâmetro, verificou-se que as concentrações de nitrato foram baixas (média de 5 à $6 \mathrm{mg} / \mathrm{L}$, na Tabela 5.9), face à oxidação 
praticamente total de aproximadamente $50 \mathrm{mg} / \mathrm{L}$ de amônia, Tabela 5.9. Embora seja possível a ocorrência de desnitrificação nos períodos sem aeração, é pouco provável que tenha ocorrido de forma tão significante.

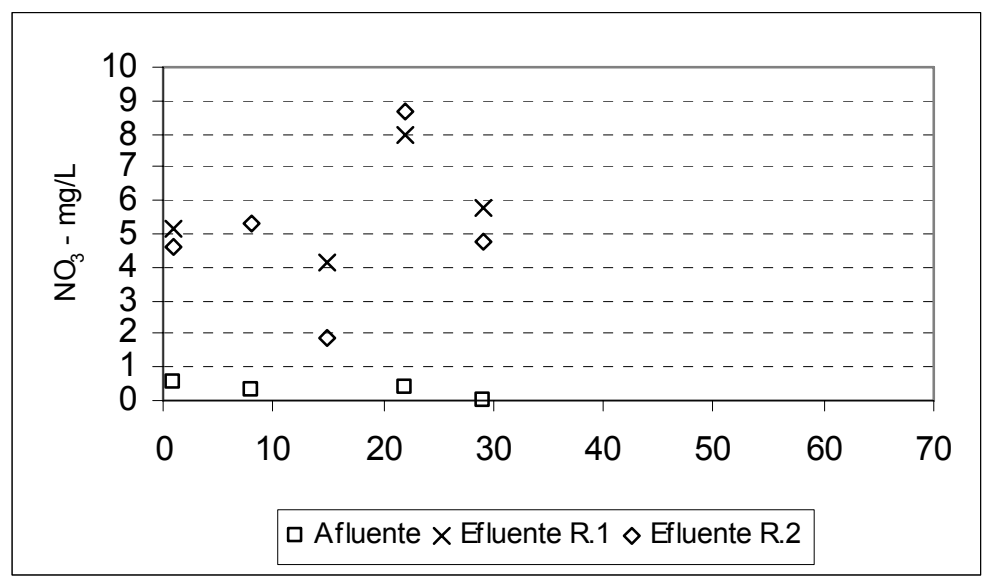

Figura 5.10 - Séries temporais de nitrato do esgoto afluente e efluente da ETE Juquitiba, sem o lançamento do lodo da ETA no sistema de esgotos

A Figura 5.10 ilustra a produção de nitrato tanto pelo reator 1, quanto pelo reator 2. Isto é uma característica do sistema de lodo ativado com aeração prolongada, ou idade do lodo alta. Verificou-se nesta Figura que houve a interrupção da apresentação dos dados próximo do trigésimo dia deste período.

Tabela 5.10 - Resultados dos parâmetros fósforo total e solúvel do esgoto afluente e tratado da ETE Juquitiba, sem o lançamento do lodo da ETA no sistema de esgotos

\begin{tabular}{ccccccc}
\hline Parâmetro & Ponto & $\mathrm{n}$ & Média & $\begin{array}{c}\text { Desvio } \\
\text { padrão }\end{array}$ & $\begin{array}{c}\text { Erro } \\
\text { padrão }\end{array}$ & $\begin{array}{c}\text { Intervalo de } \\
\text { confiança }(95 \%)\end{array}$ \\
\hline Fósforo Total $(\mathrm{mg} / \mathrm{L})$ & Afluente & 9 & 8,92 & 1,26 & 0,42 & {$[8,09 ; 9,74]$} \\
& Efluente R.1 & 5 & 3,00 & 1,33 & 0,60 & {$[1,83 ; 4,17]$} \\
& Efluente R.2 & 4 & 4,21 & 2,02 & 1,01 & {$[2,23 ; 6,19]$} \\
Fósforo Solúvel (mg/L) & Afluente & 9 & 5,95 & 1,55 & 0,52 & {$[4,93 ; 6,96]$} \\
& Efluente R.1 & 5 & 2,15 & 1,21 & 0,54 & {$[1,09 ; 3,21]$} \\
& Efluente R.2 & 5 & 2,65 & 1,67 & 0,75 & {$[1,19 ; 4,12]$} \\
\hline
\end{tabular}

$\mathrm{Na}$ Tabela 5.10 verificou-se valores também típicos de concentrações de fósforo total e solúvel para o esgoto bruto e concentrações relativamente baixas nos efluentes, para este sistema de tratamento de esgotos sem unidades, ou fases, seletoras para este fim. Porém, são resultados característicos de sistemas de lodo ativado com aeração prolongada onde a concentração de SSV é elevada e 
conseqüentemente a produção de lodo de excesso também, consumindo para isso o fósforo.

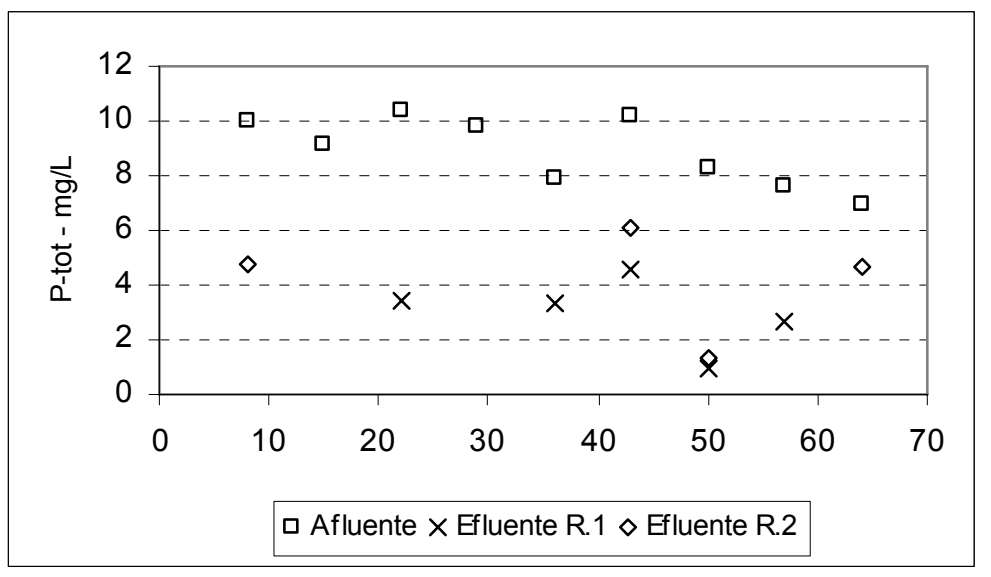

Figura 5.11 - Séries temporais de fósforo total do esgoto afluente e efluente da ETE Juquitiba, sem o lançamento do lodo da ETA no sistema de esgotos

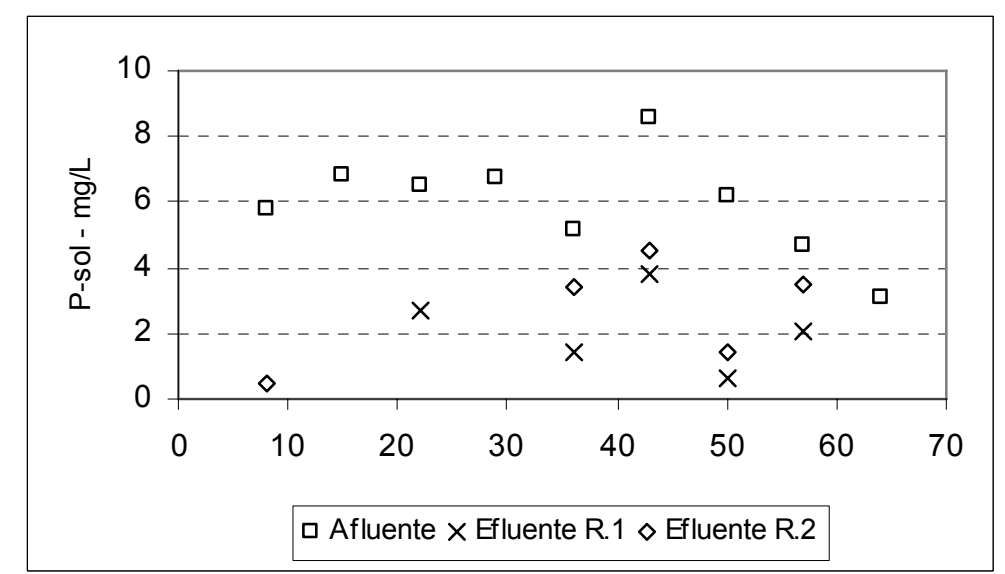

Figura 5.12 - Séries temporais de fósforo solúvel do esgoto afluente e efluente da ETE Juquitiba, sem o lançamento do lodo da ETA no sistema de esgotos

As Figuras 5.11 e 5.12 ilustram a Tabela 5.10 e possibilitam verificar que a aplicação de fósforo pelo esgoto bruto tende a acompanhar a carga de DBO e DQO aplicada no sistema, como visto nas Figuras 5.3 e 5.4 .

Os parâmetros OD, temperatura, $\mathrm{pH}$ e alcalinidade também foram medidos e apresentaram resultados típicos de esgoto doméstico e de lodo de sistema de tratamento de esgotos por lodo ativado com aeração prolongada. Na Tabela 5.11 foi possível verificar, através dos dados da temperatura, condições extremas para a região geográfica estudada, de clima tropical, confirmando o período medido de inverno. 
Tabela 5.11 - Resultados dos parâmetros oxigênio dissolvido, temperatura, pH e alcalinidade do esgoto afluente, tratado e do lodo dos reatores biológicos da ETE Juquitiba, sem o lançamento do lodo da ETA no sistema de esgotos

\begin{tabular}{ccccccc}
\hline Parâmetro & Ponto & $\mathrm{n}$ & Média & $\begin{array}{c}\text { Desvio } \\
\text { padrão }\end{array}$ & $\begin{array}{c}\text { Erro } \\
\text { padrão }\end{array}$ & $\begin{array}{c}\text { Intervalo de } \\
\text { confiança }(95 \%)\end{array}$ \\
\hline OD $(\mathrm{mg} / \mathrm{L})$ & Lodo R.1 & 5 & 1,86 & 0,74 & 0,33 & {$[1,21 ; 2,51]$} \\
& Lodo R.2 & 6 & 2,68 & 1,47 & 0,60 & {$[1,50 ; 3,86]$} \\
Temperatura $\left({ }^{\circ} \mathrm{C}\right)$ & Afluente & 3 & 18,17 & 1,26 & 0,73 & {$[16,74 ; 19,59]$} \\
& Lodo R.1 & 5 & 17,80 & 1,35 & 0,60 & {$[16,62 ; 18,98]$} \\
& Lodo R.2 & 5 & 17,82 & 0,85 & 0,38 & {$[17,08 ; 18,56]$} \\
& Efluente R.1 & 5 & 18,64 & 1,50 & 0,67 & {$[17,32 ; 19,96]$} \\
& Efluente R.2 & 5 & 18,32 & 1,34 & 0,60 & {$[17,15 ; 19,49]$} \\
& Afluente & 8 & 7,06 & 0,20 & 0,07 & {$[6,92 ; 7,19]$} \\
& Lodo R.1 & 8 & 6,54 & 0,34 & 0,12 & {$[6,30 ; 6,77]$} \\
& Lodo R.2 & 7 & 6,60 & 0,47 & 0,18 & {$[6,25 ; 6,94]$} \\
& Efluente R.1 & 7 & 6,75 & 0,15 & 0,06 & {$[6,64 ; 6,86]$} \\
& Efluente R.2 & 8 & 6,82 & 0,18 & 0,06 & {$[6,69 ; 6,94]$} \\
& Afluente & 8 & 211,88 & 51,27 & 18,13 & {$[176 ; 247]$} \\
& Efluente R.1 & 8 & 51,88 & 22,26 & 7,87 & {$[36,45 ; 67,30]$} \\
& Efluente R.2 & 8 & 60,38 & 37,66 & 13,31 & {$[34,28 ; 86,47]$} \\
\hline
\end{tabular}

Os sistemas de lodo ativado com aeração prolongada exigem uma concentração mínima de OD de 1,5 mg/L (NBR-570), nos reatores biológicos, verificou-se tanto na Tabela 5.11, quanto na Figura, 5.13 que os dois reatores atenderam este requisito na sua maior parte do tempo.

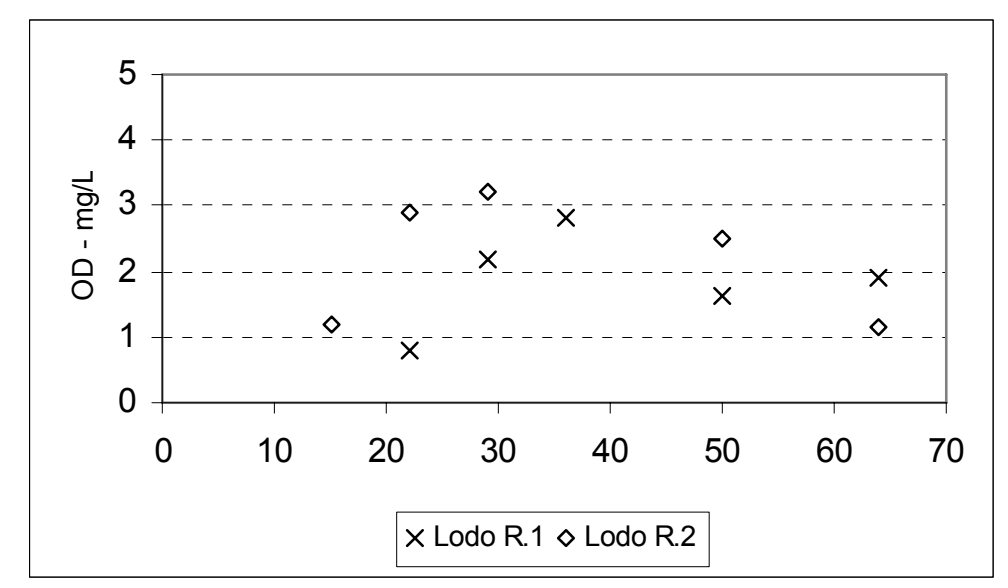

Figura 5.13 - Séries temporais de OD do lodo dos reatores biológicos 1 e 2 da ETE Juquitiba, sem o lançamento do lodo da ETA no sistema de esgotos 


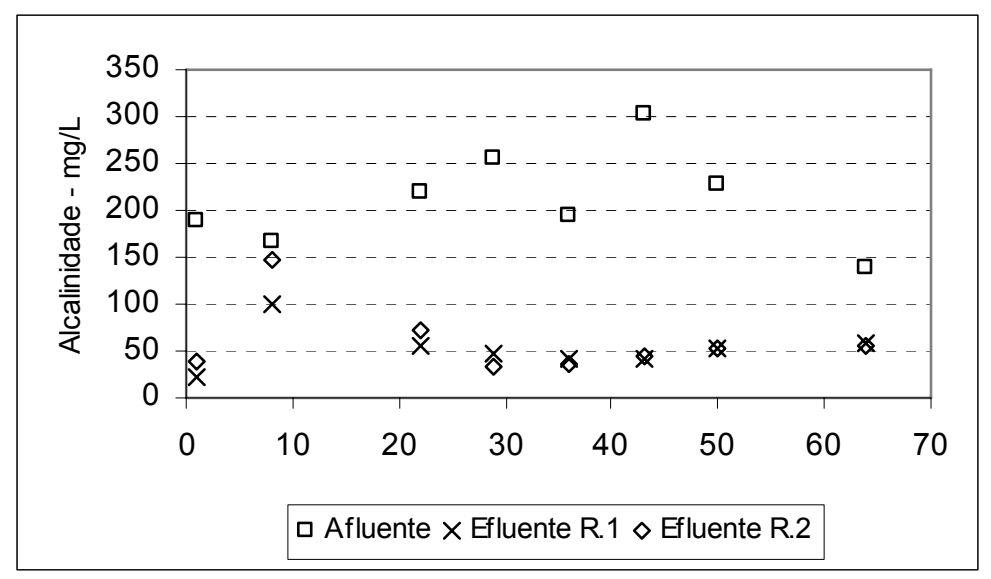

Figura 5.14 - Séries temporais de alcalinidade do esgoto afluente e tratado da ETE Juquitiba, sem o lançamento do lodo da ETA no sistema de esgotos

Verificou-se, ainda, que o esgoto afluente apresenta concentrações características de efluentes domésticos para o parâmetro alcalinidade e, o efluente tratado da ETE possui a alcalinidade típica de sistemas de lodo ativado com aeração prolongada. Porém, a fim de verificar a variação de alcalinidade teórica, de acordo com Van Haandel (1999), e compararmos com a variação real, realizou-se os seguintes cálculos: (1) segundo Van Haandel (1999) $\Delta$ alcalinidade total $=3,57$ $x\left(\Delta N_{\text {Amoniacal }}-\Delta N_{\text {Nnitrato }}\right)$, sendo $\Delta$ alc. tot. $=149 \mathrm{mg} / \mathrm{L}$ e (2) a variação real medida de alcalinidade igual $155 \mathrm{mg} / \mathrm{L}$. Verificou-se que com dados tão próximos existe a possibilidade de ter realmente ocorrido a desnitrificação no reator biológico.

$\mathrm{O}$ pH também apresentou uma queda do afluente para o lodo do reator biológico e uma recuperação no efluente tratado da estação.

Tabela 5.12 - Eficiências obtidas pela remoção dos parâmetros $\mathrm{DBO}_{5,20}$, DQO, NKT, nitrogênio amoniacal, fósforo total e solúvel do esgoto afluente da ETE Juquitiba, sem o lançamento do lodo da ETA no sistema de esgotos (continua)

\begin{tabular}{ccccccc}
\hline Parâmetro & Ponto & $\mathrm{n}$ & Média & $\begin{array}{c}\text { Desvio } \\
\text { padrão }\end{array}$ & $\begin{array}{c}\text { Erro } \\
\text { padrão }\end{array}$ & $\begin{array}{c}\text { Intervalo de } \\
\text { confiança }(95 \%)\end{array}$ \\
\hline DBO $_{5,20}$ & Efic R.1 $(\%)$ & 5 & 90,40 & 5,26 & 2,35 & {$[85,79 ; 95,01]$} \\
& Efic R.2 $(\%)$ & 8 & 83,76 & 7,47 & 2,64 & {$[78,59 ; 88,94]$} \\
\multirow{2}{*}{ DQO } & Efic R.1 (\%) & 5 & 92,11 & 6,44 & 2,88 & {$[86,47 ; 97,75]$} \\
& Efic R.2 (\%) & 9 & 87,13 & 5,47 & 1,82 & {$[83,56 ; 90,71]$} \\
NKT & Efic R.1 (\%) & 5 & 91,51 & 5,03 & 2,25 & {$[87,10 ; 95,91]$} \\
& Efic R.2 (\%) & 5 & 88,03 & 3,67 & 1,64 & {$[84,81 ; 91,25]$}
\end{tabular}


Tabela 5.12 - Eficiências obtidas pela remoção dos parâmetros DBO5,20, DQO, NKT, nitrogênio amoniacal, fósforo total e solúvel do esgoto afluente da ETE Juquitiba, sem o lançamento do lodo da ETA no sistema de esgotos (conclusão)

\begin{tabular}{ccccccc}
\hline Parâmetro & Ponto & $\mathrm{n}$ & Média & $\begin{array}{c}\text { Desvio } \\
\text { padrão }\end{array}$ & $\begin{array}{c}\text { Erro } \\
\text { padrão }\end{array}$ & $\begin{array}{c}\text { Intervalo de } \\
\text { confiança }(95 \%)\end{array}$ \\
\hline N-amonia. & Efic R.1 (\%) & 10 & 94,04 & 6,91 & 2,19 & {$[89,76 ; 98,32]$} \\
& Efic R.2 (\%) & 7 & 97,84 & 3,21 & 1,21 & {$[95,46 ; 100,22]$} \\
Fósforo Total & Efic R.1 (\%) & 5 & 66,58 & 13,09 & 5,86 & {$[55,11 ; 78,06]$} \\
& Efic R.2 (\%) & 4 & 52,34 & 22,50 & 11,25 & {$[30,29 ; 74,39]$} \\
Fósforo Solúvel & Efic R.1 (\%) & 5 & 65,99 & 14,70 & 6,57 & {$[53,11 ; 78,87]$} \\
& Efic R.2 (\%) & 5 & 55,21 & 28,64 & 12,81 & {$[30,10 ; 80,31]$} \\
\hline
\end{tabular}

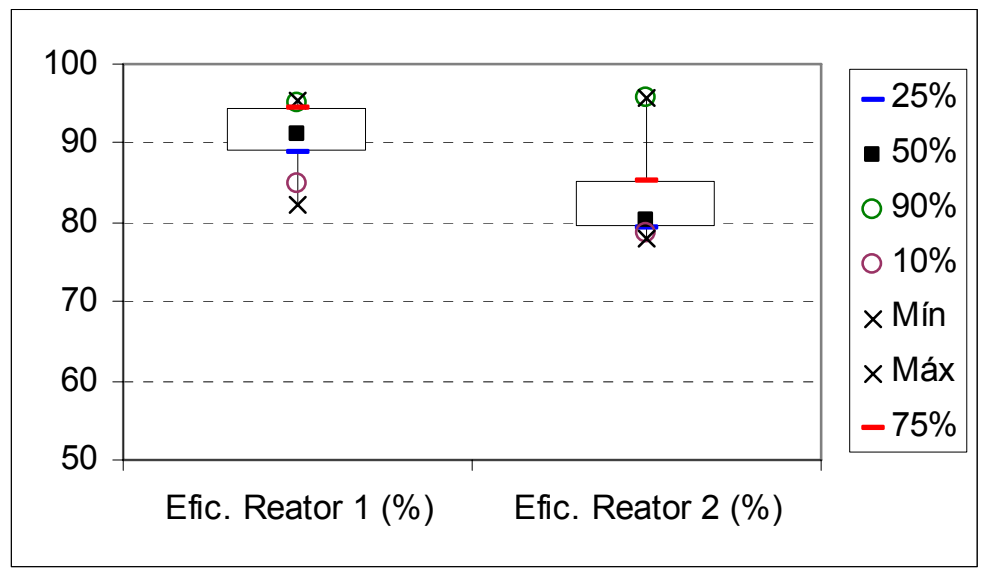

Figura 5.15 - Diagrama "box-plot" da eficiência de remoção de $\mathrm{DBO}_{5,20}$ do esgoto bruto pela ETE Juquitiba, sem o lançamento do lodo da ETA no sistema de esgotos

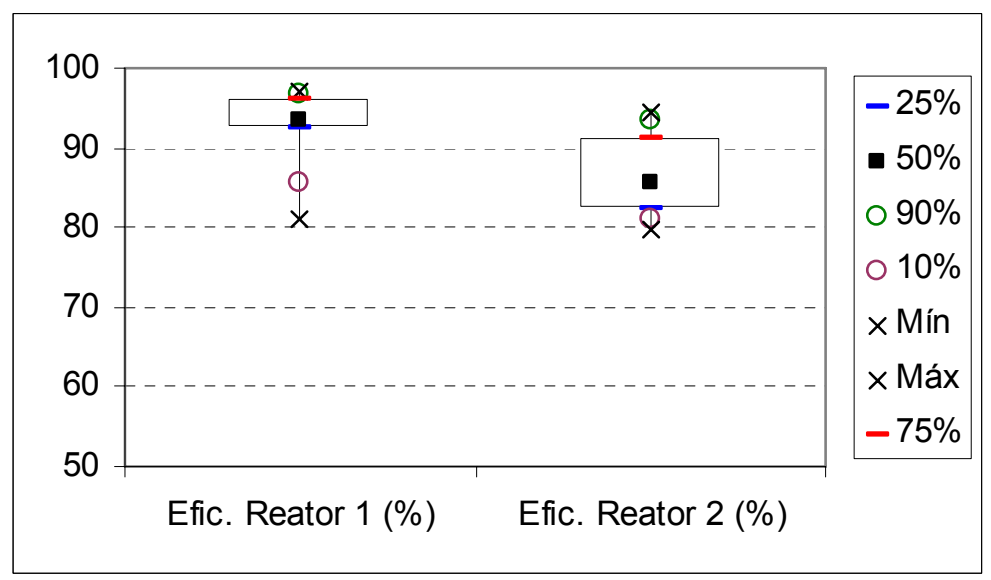

Figura 5.16 - Diagrama "box-plot" da eficiência de remoção de DQO do esgoto bruto pela ETE Juquitiba, sem o lançamento do lodo da ETA no sistema de esgotos 
Em análise à Tabela 5.12 e ainda verificado nas Figuras 5.15 e 5.16 as eficiências na remoção de DBO e DQO apresentaram-se superiores no reator biológico 1. Os dois reatores apresentaram boa eficiência,porém para o sistema de tratamento em questão seria esperado um melhor resultado de remoção destes parâmetros para o reator biológico 2. Os resultados apresentados nestas Figuras ilustram bem as condições de operação de lodo ativado com reatores seqüenciais em bateladas, onde o aporte de "alimento" em cada reator biológico ocorre em tempos diferentes, conseqüentemente com concentrações diferentes.

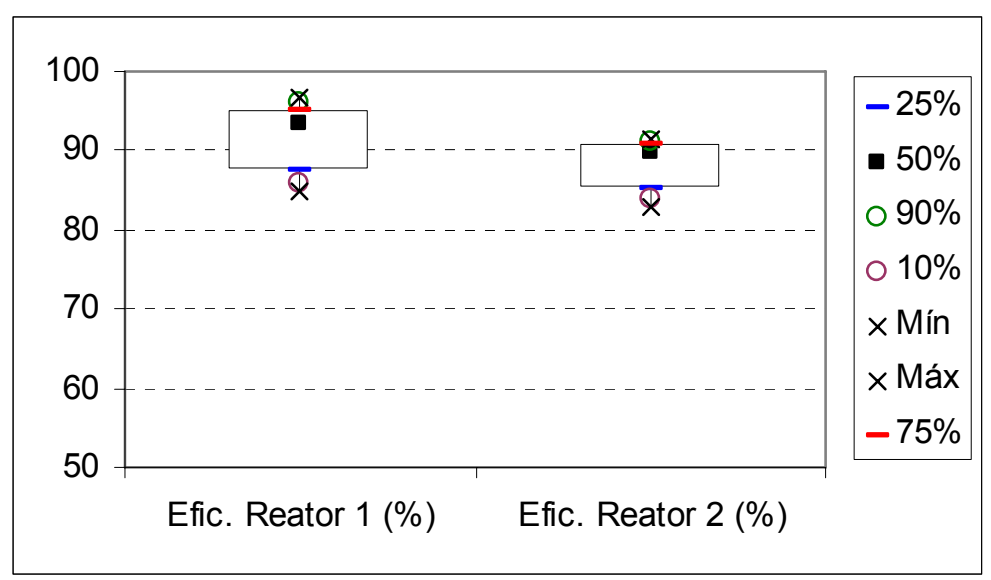

Figura 5.17 - Diagrama "box-plot" da eficiência de remoção de NKT do esgoto bruto pela ETE Juquitiba, sem o lançamento do lodo da ETA no sistema de esgotos

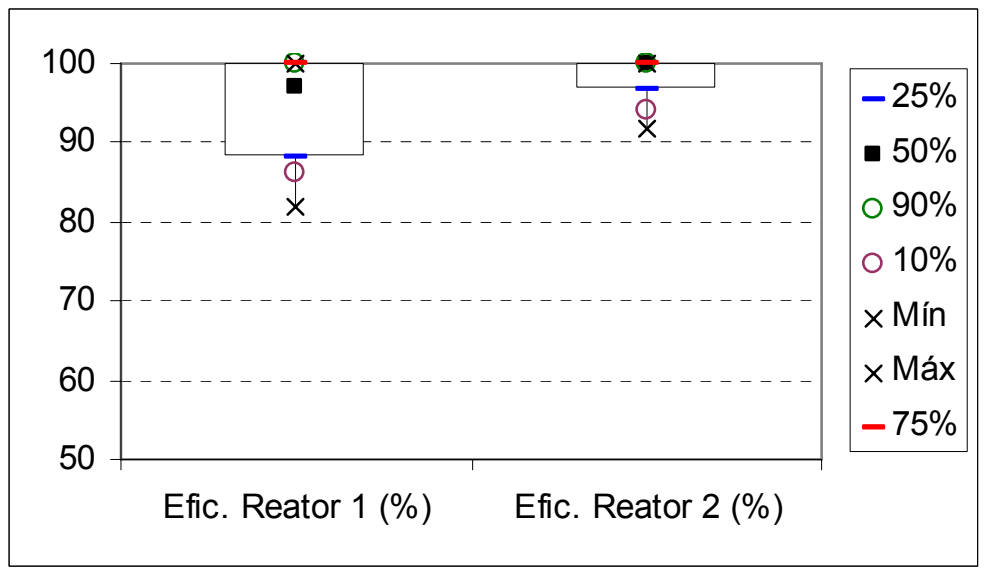

Figura 5.18 - Diagrama "box-plot" da eficiência de remoção de nitrogênio amoniacal do esgoto bruto pela ETE Juquitiba, sem o lançamento do lodo da ETA no sistema de esgotos

A estação apresentou uma boa remoção de nitrogênio amoniacal, típico de sistemas de tratamento de esgotos por lodo ativado com aeração prolongada, até 
uma considerável remoção de NKT, como ilustrado nas Figuras 5.17 e 5.18, além do esperado para este sistema sem unidade seletora para este fim.

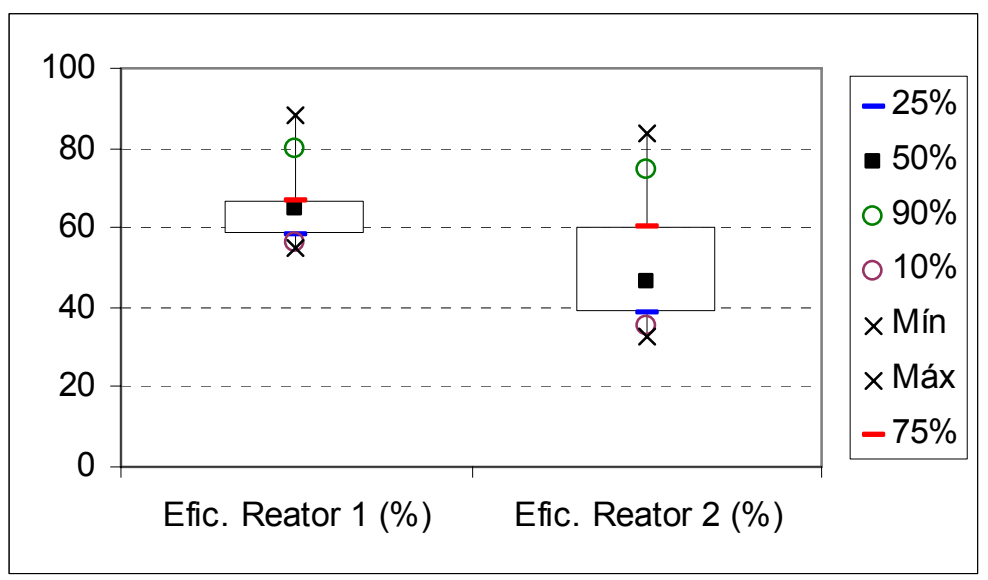

Figura 5.19 - Diagrama "box-plot" da eficiência de remoção de fósforo total do esgoto bruto pela ETE Juquitiba, sem o lançamento do lodo da ETA no sistema de esgotos

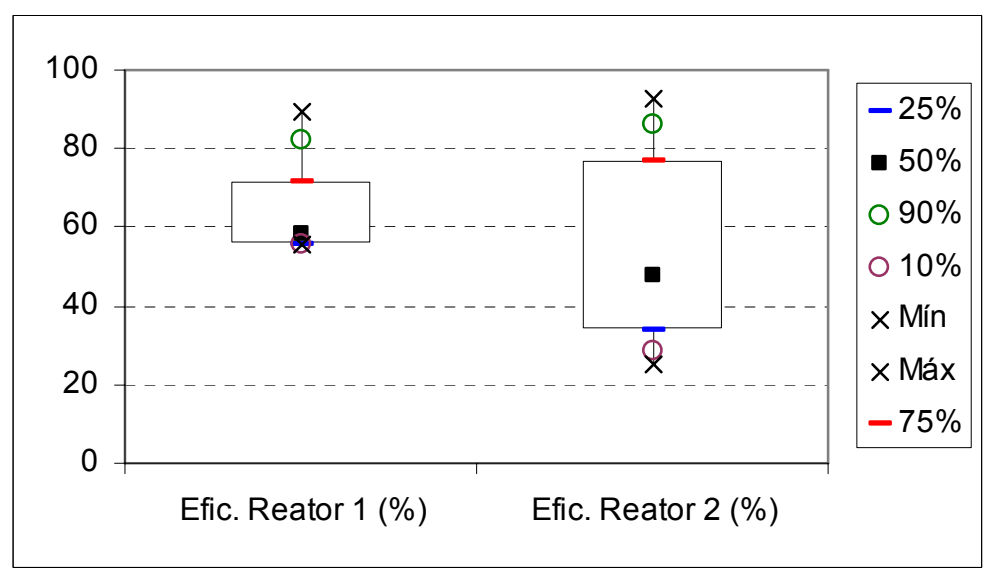

Figura 5.20 - Diagrama "box-plot" da eficiência de remoção de fósforo solúvel do esgoto bruto pela ETE Juquitiba, sem o lançamento do lodo da ETA no sistema de esgotos

A remoção de fósforo do esgoto apresentou características típicas de sistema de tratamento em questão, onde deve ocorrer a captura do fósforo do afluente para a produção de lodo de excesso.

Os dados apresentados neste tópico permitiram verificar as condições de tratamento dos esgotos pela ETE Juquitiba, sendo dados coerentes com a teoria e literatura do processo de tratamento de esgotos domésticos por lodo ativado com aeração prolongada, e com reatores seqüenciais em bateladas. 


\section{4- Caracterização do esgoto bruto, tratado e do lodo do reator biológico da ETE, após o início do lançamento do lodo da ETA no sistema de esgotos}

O período de identificação dos parâmetros referidos na metodologia da estação de tratamento de esgotos, após do início do lançamento do lodo da ETA no sistema de esgotos, está compreendido entre 2 de agosto e 15 dezembro de 2006.

Trata-se do período em que a estação de tratamento de esgotos foi operada, também em regime uniforme de operação com o controle da idade do lodo de 25 dias e que houve o aporte dos resíduos gerados pela estação de tratamento de água, via rede coletora de esgotos.

Com esta nova condição dos afluentes da ETE, verificaram-se alterações nos números relatados na condição apresentada anteriormente, sejam nas vazões, sejam nos parâmetros, então serão apresentados os dados deste último período pesquisado, com considerações em relação àqueles já descritos anteriormente.

Tabela 5.13 - Vazões de esgoto afluente à ETE Juquitiba nos períodos de 24 de maio à 26 de julho e 2 de agosto à 15 de novembro de 2006

\begin{tabular}{ccc}
\hline & Vazão $\left(\mathrm{m}^{3} / \mathrm{dia}\right)$ & Vazão $\left(\mathrm{m}^{3} / \mathrm{dia}\right)$ \\
& Período: $24 / 05 / 06$ à 26/07/06 & Período: $02 / 08 / 06$ à 15/11/06 \\
\hline Número de dados & 59 & 61 \\
Média & 346 & 431 \\
Desvio padrão & 52 & 90 \\
Mínimo & 259 & 248 \\
Máximo & 521 & 758 \\
Intervalo de confiança (95\%) & {$[332 ; 359]$} & {$[408 ; 453]$} \\
\hline
\end{tabular}

O período em que foram registrados os dados de vazões da ETE nesta terceira etapa da pesquisa corresponde ao fim da seca ou "início das águas" quando ocorreram algumas chuvas. Porém não foi feito controle sobre esta grandeza, apenas anotações no caderno de campo.

Foram verificadas vazões bem definidas ao longo deste período como descrito na Tabela 5.13. Cinco datas sobressaíram à média deste período sendo os dias 18 e 19 de agosto com $706 \mathrm{~m}^{3}$ e $610 \mathrm{~m}^{3}$ respectivamente, os dias 3 e 19 de setembro com $758 \mathrm{~m}^{3}$ e $603 \mathrm{~m}^{3}$ respectivamente e o dia 14 de novembro de 2006 com $523 \mathrm{~m}^{3}$. 
As datas de lavagem dos decantadores da estação de tratamento de água neste período da pesquisa ou seja lançando os resíduos da ETA na rede coletora de esgotos foram 18 de agosto, 17 de setembro e 18 de outubro de 2006. No entanto apenas foi registrado pelo medidor de vazões da ETE a vazão do dia 18 de agosto, sendo que nos outros dois dias o equipamento falhou. Ainda assim foi possível verificar que existiu um acréscimo de vazão no dia 18 de agosto, na ETE, de $275 \mathrm{~m}^{3}$ acima da média deste novo período, quando era esperado um acréscimo de $256 \mathrm{~m}^{3}$ devido o procedimento de lançamento dos resíduos de limpeza dos decantadores da ETA na rede coletora de esgotos.

Tabela 5.14 - Resultados dos parâmetros $\mathrm{DBO}_{5,20}$ e DQO do esgoto afluente e tratado da ETE Juquitiba, após o início do lançamento do lodo da ETA no sistema de esgotos

\begin{tabular}{ccccccc}
\hline Parâmetro & Ponto & $\mathrm{n}$ & Média & $\begin{array}{c}\text { Desvio } \\
\text { padrão }\end{array}$ & $\begin{array}{c}\text { Erro } \\
\text { padrão }\end{array}$ & $\begin{array}{c}\text { Intervalo de } \\
\text { confiança }(95 \%)\end{array}$ \\
\hline DBO5,20 $(\mathrm{mg} / \mathrm{L})$ & Afluente & 6 & 331,00 & 106,08 & 5,83 & {$[319 ; 342]$} \\
& Efluente R.1 & 5 & 50,60 & 20,62 & 2,90 & {$[44,92 ; 56,28]$} \\
& Efluente R.2 & 4 & 47,00 & 9,59 & 1,40 & {$[44,26 ; 49,74]$} \\
DQO (mg/L) & Afluente & 7 & 622,00 & 107,23 & 4,30 & {$[613 ; 630]$} \\
& Efluente R.1 & 6 & 88,67 & 38,47 & 4,09 & {$[80,66 ; 96,67]$} \\
& Efluente R.2 & 7 & 83,00 & 51,78 & 5,68 & {$[71,86 ; 94,14]$} \\
\hline
\end{tabular}

Nesta etapa da pesquisa foi possível verificar uma sensível diminuição tanto na DBO quanto na DQO afluente como apresentado na Tabela 5.14. Comparando com os dados do período anterior sem o lançamento do lodo da ETA no sistema de esgotos, Tabela 5.7, os resultados indicam uma diluição do esgoto afluente devido o aumento de sua vazão.

No que diz respeito ao efluente tratado da estação, verificou-se uma diminuição na qualidade do efluente do reator 1 e uma sensível melhora na qualidade do efluente do reator 2. Porém no caso do reator 2 os intervalos de confiança se sobrepôem indicando que não houve alteração. 


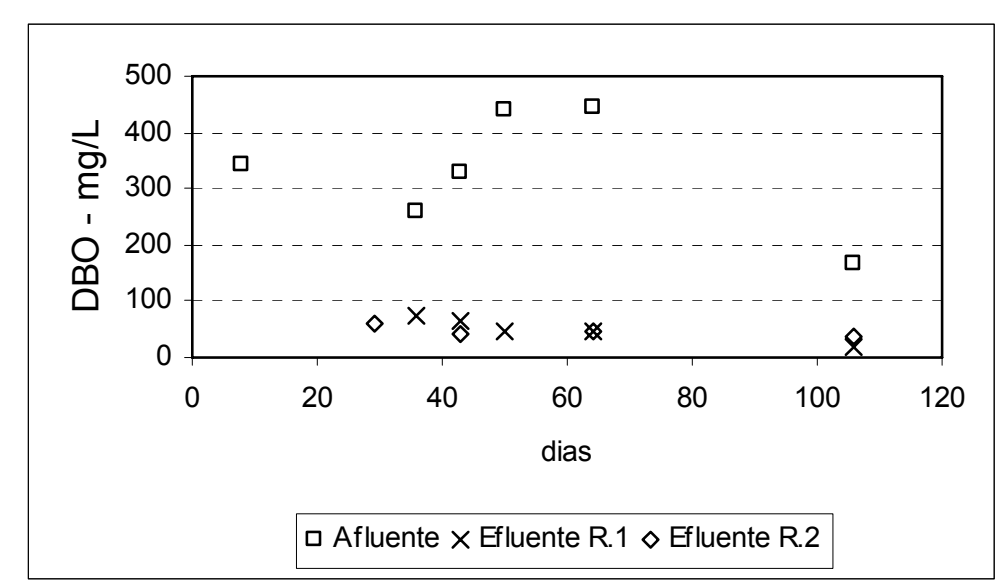

Figura 5.21 - Séries temporais de $\mathrm{DBO}_{5,20}$ do esgoto afluente e efluente da ETE Juquitiba, após o início do lançamento do lodo da ETA no sistema de esgotos

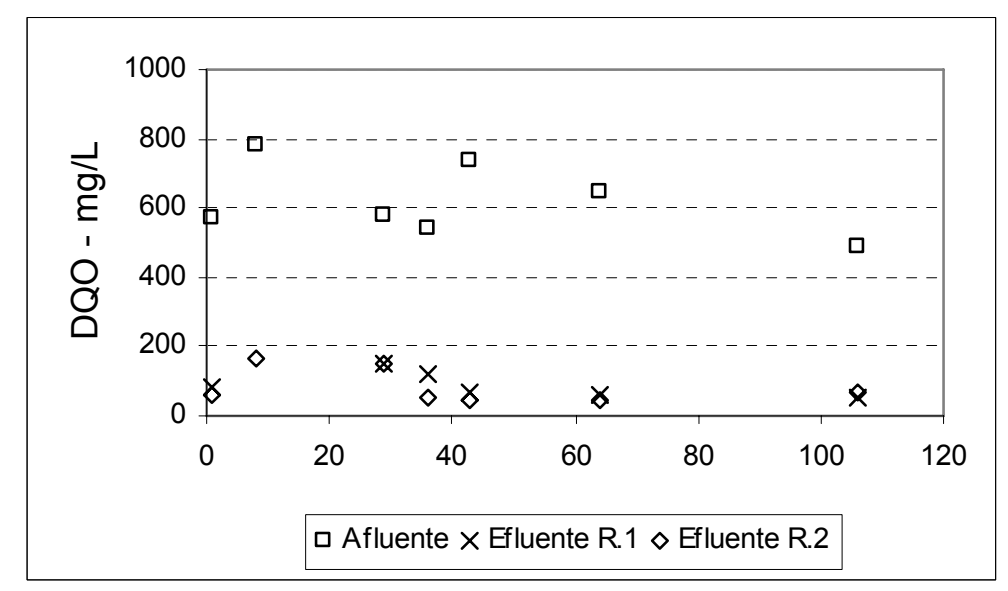

Figura 5.22 - Séries temporais de DQO do esgoto afluente e efluente da ETE Juquitiba, após o início do lançamento do lodo da ETA no sistema de esgotos

As Figuras 5.21 e 5.22 ilustram os resultados dos parâmetros $\mathrm{DBO}_{5,20}$ e DQO e possibilitam verificar que existiu uma uniformidade entre os resultados dos efluentes dos dois reatores biológicos, quando comparado com o período anterior.

As Figura 5.23 e 5.24 são diagramas "box-plot" dos resutados de $\mathrm{DBO}_{5,20}$, sendo apresentado na Figura 5.23 os diagramas referentes ao primeiro período, sem lançamento de lodo da ETE no sistema de esgotos e, na Figura 5.24, os diagramas referentes ao segundo período, após o início do lançamento do lodo da ETA no sistema de esgotos. Assim, evidencia-se eventuais diferenças entre os dois períodos. 


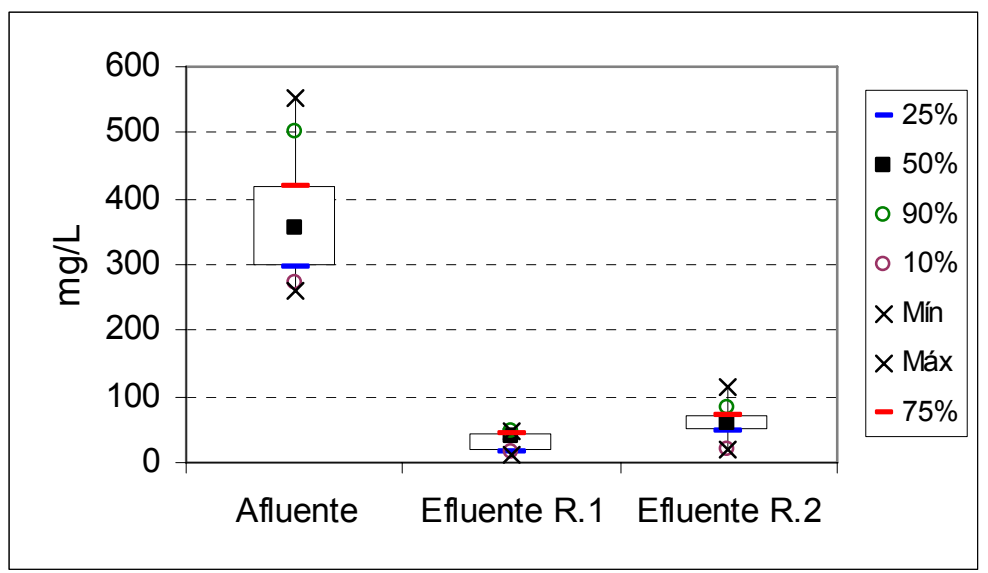

Figura 5.23 - Diagrama "Box-plot" de $\mathrm{DBO}_{5,20}$ do esgoto bruto e tratado da ETE Juquitiba, sem o lançamento do lodo da ETA no sistema de esgotos

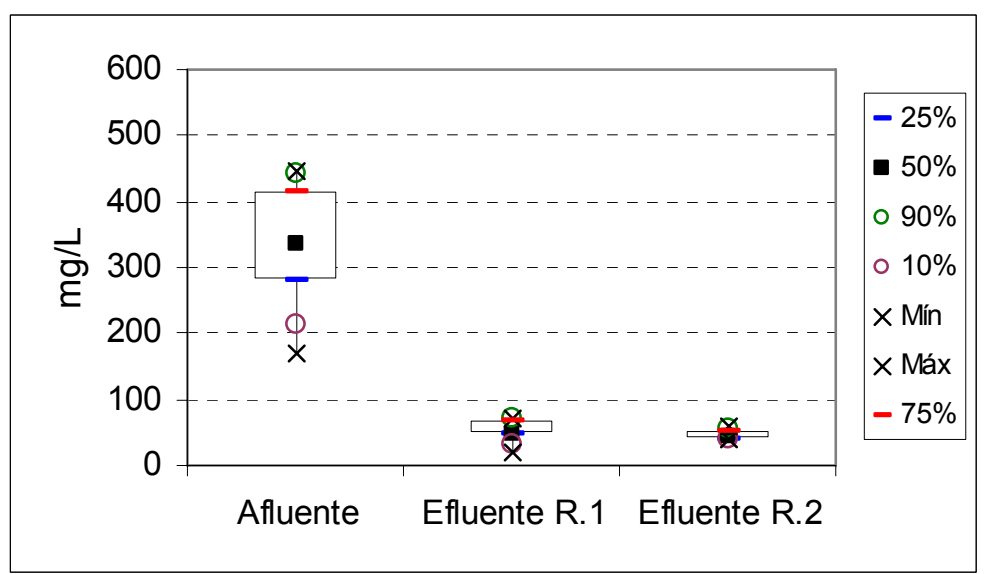

Figura 5.24 - Diagrama "Box-plot" de $\mathrm{DBO}_{5,20}$ do esgoto bruto e tratado da ETE Juquitiba, após o início do lançamento do lodo da ETA no sistema de esgotos

Pelas Figuras 5.23 e 5.24 verificou-se que não houvera alterações nas concentrações de DBO dos efluentes dos reatores 1 e 2, após o início do lançamento do lodo da ETA no sistema de esgotos 
Tabela 5.15 - Resultados dos parâmetros sólidos em suspensão totais, voláteis e fixos do esgoto afluente, tratado e do lodo dos reatores biológicos da ETE Juquitiba, após o início do lançamento do lodo da ETA no sistema de esgotos

\begin{tabular}{ccccccc}
\hline Parâmetro & Ponto & $\mathrm{n}$ & Média & $\begin{array}{c}\text { Desvio } \\
\text { padrão }\end{array}$ & $\begin{array}{c}\text { Erro } \\
\text { padrão }\end{array}$ & $\begin{array}{c}\text { Intervalo de } \\
\text { confiança }(95 \%)\end{array}$ \\
\hline SST $(\mathrm{mg} / \mathrm{L})$ & Afluente & 8 & 335 & 139,33 & 7,61 & {$[320 ; 350]$} \\
& Lodo R.1 & 8 & 2.853 & 652,25 & 12,21 & {$[2829 ; 2877]$} \\
& Lodo R.2 & 8 & 3.417 & 277,88 & 4,75 & {$[3408 ; 3426]$} \\
& Efluente R.1 & 8 & 68 & 32,17 & 3,89 & {$[60,88 ; 76,12]$} \\
& Efluente R.2 & 6 & 66 & 66,93 & 8,20 & {$[50,60 ; 82,73]$} \\
SSV $(\mathrm{mg} / \mathrm{L})$ & Afluente & 8 & 226 & 93,44 & 6,21 & {$[214 ; 238]$} \\
& Lodo R.1 & 8 & 1.935 & 412,38 & 9,37 & {$[1916 ; 1953]$} \\
& Lodo R.2 & 8 & 2.292 & 139,23 & 2,91 & {$[2286 ; 2298]$} \\
& Efluente R.1 & 8 & 53 & 21,14 & 2,90 & {$[47,31 ; 58,69]$} \\
& Efluente R.2 & 6 & 48 & 45,96 & 6,61 & {$[35,38 ; 61,29]$} \\
SSF $(\mathrm{mg} / \mathrm{L})$ & Afluente & 8 & 102 & 70,49 & 6,96 & {$[88,85 ; 116,15]$} \\
& Lodo R.1 & 8 & 918 & 261,50 & 8,63 & {$[901 ; 935]$} \\
& Lodo R.2 & 8 & 1.125 & 154,89 & 4,62 & {$[1115 ; 1134]$} \\
& Efluente R.1 & 8 & 15 & 13,43 & 3,41 & {$[8,82 ; 22,18]$} \\
& Efluente R.2 & 6 & 18 & 21,11 & 4,93 & {$[8,67 ; 27,99]$} \\
\hline
\end{tabular}

A partir da Tabela 5.15, verificou-se as novas relações SSVISST do lodo os reatores biológicos 1 e 2 sendo 0,68 e 0,67, respectivamente, apresentando-se para o reator 1 o mesmo resultado que aquele obtido antas do lançamento do lodo da ETA na ETE e para o reator 2, um resultado $8 \%$ menor nesta nova situação que o obtido anteriormente. A relação SSVISST obtida para o esgoto bruto foi de 0,67 apresentando a diminuição de $17,3 \%$ em relação ao resultado obtido antes dol lançamento do lodo da ETA na ETE.

A carga de sólidos em suspensão total aplicada na ETE na situação antes do início do lançamento do lodo da ETA no sistema de esgotos foi de $112 \mathrm{Kg} . \mathrm{SST} / \mathrm{dia}$ (calculado pela vazão e concentração, Tabelas 5.6 e 5.8). Na situação seguinte foi de $144 \mathrm{Kg} . S S T / d i a$ (calculado pela vazão e concentração, Tabelas 5.13 e 5.15). Portanto, ocorreu um acréscimo de $32 \mathrm{Kg}$ de SST aplicado na ETE pelo esgoto bruto por dia.

O mesmo cálculo foi realizado para a aplicação de SSV na ETE com os seguintes resultados: $91 \mathrm{Kg} . \mathrm{SSV} /$ dia antes e $97 \mathrm{Kg} . \mathrm{SSV} /$ dia depois, também para SSF os seguintes resultados: $21 \mathrm{Kg} . \mathrm{SSF} / \mathrm{dia}$ antes e $44 \mathrm{Kg} . \mathrm{SSF} / \mathrm{dia}$ depois, 
apresentando-se os respectivos acréscimos destes sólidos do período antes do lançamento do lodo da ETA na ETE para o período depois de $6 \mathrm{Kg} . \mathrm{SSV} /$ dia e 23 Kg.SSF /dia.

A relação SSVISST do lodo da ETA é igual à $0,3 \mathrm{Kg}$.SSV/Kg.SST aproximadamente (Tabela 5.5) e se aplicada ao acréscimo encontrado de 32 Kg.SST/dia, tem-se $9 \mathrm{Kg} . S S V / d i a$ e $22 \mathrm{Kg} . S S F / d i a$. Tais valores são muito próximos aos valores obtidos anteriormente de 6 kg.SSV/dia e $23 \mathrm{Kg} . S S F / d i a$.

Com isso admitiu-se que foi realizada efetivamente a aplicação de 32 Kg.SST/dia na ETE devido aos procedimentos de lavagem das unidades da ETA com lançamento de seus resíduos no sistema de esgoto. Ou ainda $74 \mathrm{mg}$ de lodo de ETA por litro de esgoto.

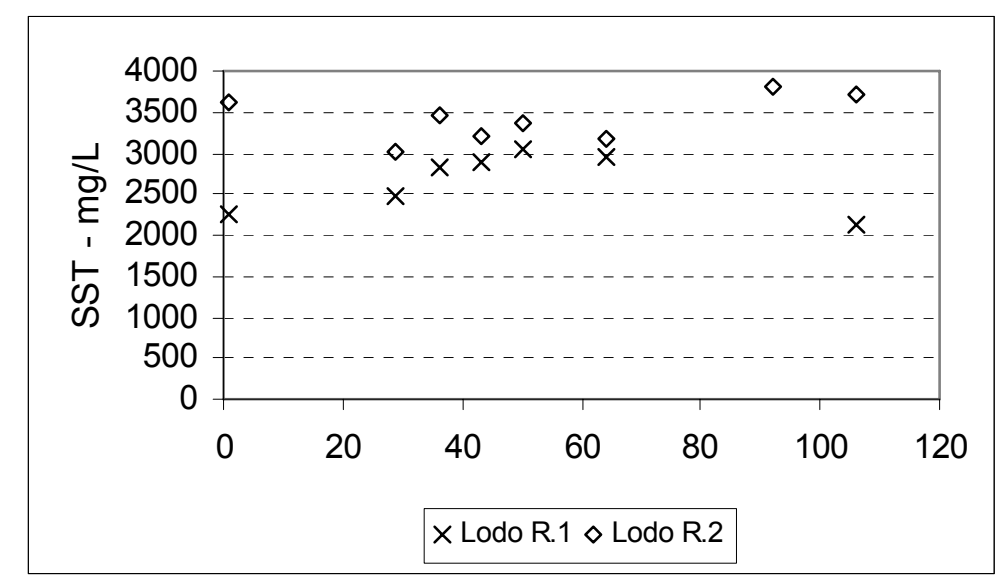

Figura 5.25 - Séries temporais de sólidos em suspensão totais do lodo dos reatores biológicos 1 e 2 da ETE Juquitiba, após o início do lançamento do lodo da ETA no sistema de esgotos

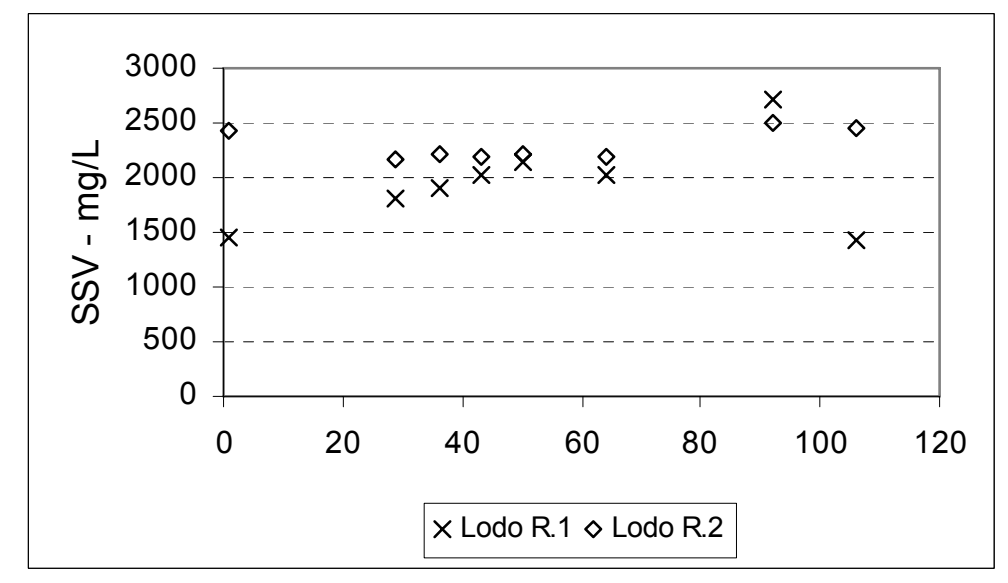

Figura 5.26 - Séries temporais de sólidos em suspensão voláteis do lodo dos reatores biológicos 1 e 2 da ETE Juquitiba, após o início do lançamento do lodo da ETA no sistema de esgotos 


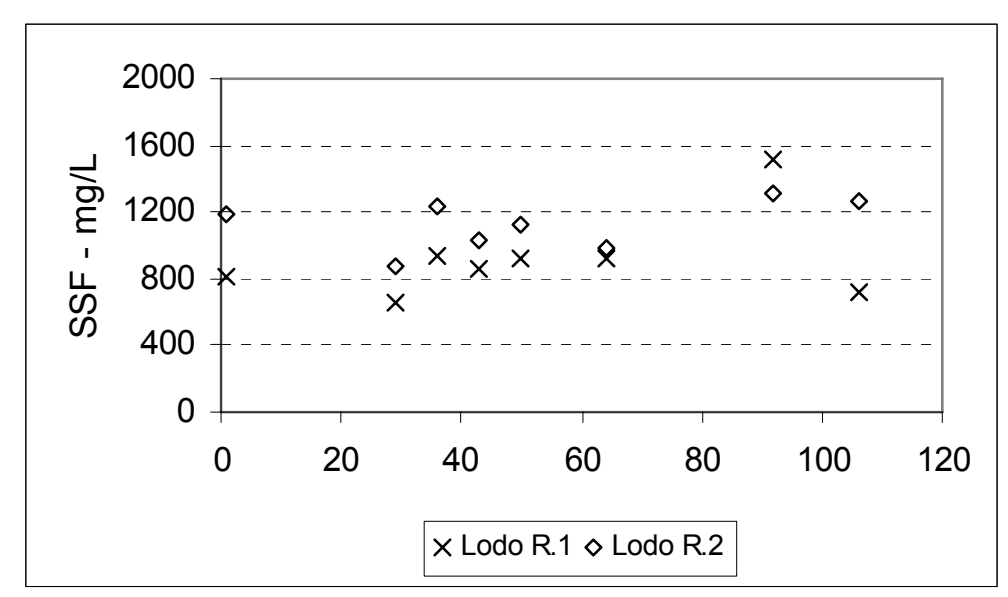

Figura 5.27 - Séries temporais de sólidos em suspensão fixos do lodo dos reatores biológicos 1 e 2 da ETE Juquitiba, após o início do lançamento do lodo da ETA no sistema de esgotos

Fazendo-se uma análise com as Tabelas 5.13, 5.14 e 5.15 e, sabendo o volume dos reatores quando cheios $\left(900 \mathrm{~m}^{3}\right)$ verificou-se a relação alimento/microrganismo ( $\mathrm{A} / \mathrm{M})$ considerando a média da concentração de sólidos em suspensão voláteis dos dois reatores sendo $\mathrm{A} / \mathrm{M}=0,075 \mathrm{Kg} \mathrm{DBO}{ }_{5,20} / \mathrm{Kg}$ SSVTA.dia, ou ainda, $A / M=0,141 \mathrm{Kg} D Q O / K g$ SSVTA.dia, então, não sendo observadas alterações em relação ao período anterior.

A produção de lodo pela estação pode ser calculada pelo produto da vazão de lodo de excesso pela concentração de sólidos deste lodo, somado a vazão de efluente tratado pela concentração de sólidos neste efluente. Com os dados de vazão da Tabela 5.13 e das concentrações de sólidos da Tabela 5.15, obteve-se a produção de lodo de excesso de $77,1 \mathrm{Kg} /$ dia. Nota-se que ocorreu um acréscimo de sólidos produzidos pelo sistema de $22,6 \mathrm{Kg} /$ dia após o início do lançamento do lodo da ETA na ETE, comparado com a situação anterior. A aplicação do lodo de ETA no sistema de esgoto significou um aumento na produção de sólidos pela ETE de $40 \%$. 
Tabela 5.16 - Resultados dos parâmetros NKT e nitrogênio amoniacal do esgoto afluente e tratado da ETE Juquitiba, após o início do lançamento do lodo da ETA no sistema de esgotos

\begin{tabular}{ccccccc}
\hline Parâmetro & Ponto & $\mathrm{n}$ & Média & $\begin{array}{c}\text { Desvio } \\
\text { padrão }\end{array}$ & $\begin{array}{c}\text { Erro } \\
\text { padrão }\end{array}$ & $\begin{array}{c}\text { Intervalo de } \\
\text { confiança }(95 \%)\end{array}$ \\
\hline NKT (mg/L) & Afluente & 7 & 71,35 & 4,66 & 0,55 & {$[70,27 ; 72,43]$} \\
& Efluente R.1 & 7 & 18,86 & 9,22 & 2,12 & {$[14,70 ; 23,02]$} \\
& Efluente R.2 & 5 & 18,48 & 14,97 & 3,48 & {$[11,65 ; 25,31]$} \\
N-Amoniacal (mg/L) & Afluente & 7 & 47,16 & 7,56 & 1,10 & {$[45,00 ; 49,32]$} \\
& Efluente R.1 & 6 & 8,93 & 7,22 & 2,42 & {$[4,19 ; 13,66]$} \\
& Efluente R.2 & 6 & 6,85 & 5,20 & 1,99 & {$[2,96 ; 10,75]$} \\
\hline
\end{tabular}

Neste período de análises não foram realizadas análises de nitrato, como explicado no tópico anterior.

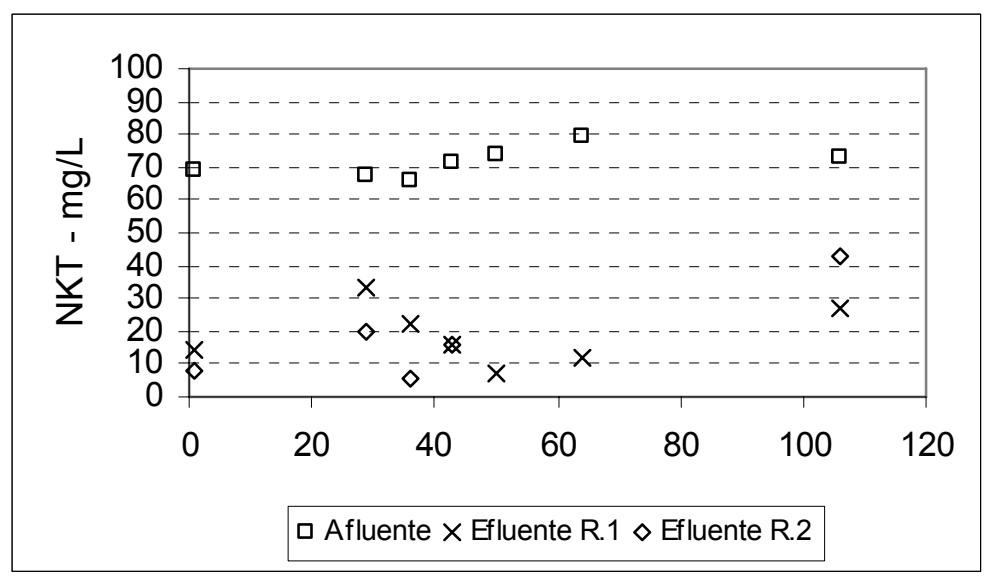

Figura 5.28 - Séries temporais de NKT do esgoto afluente e efluente da ETE Juquitiba, após o início do lançamento do lodo da ETA no sistema de esgotos

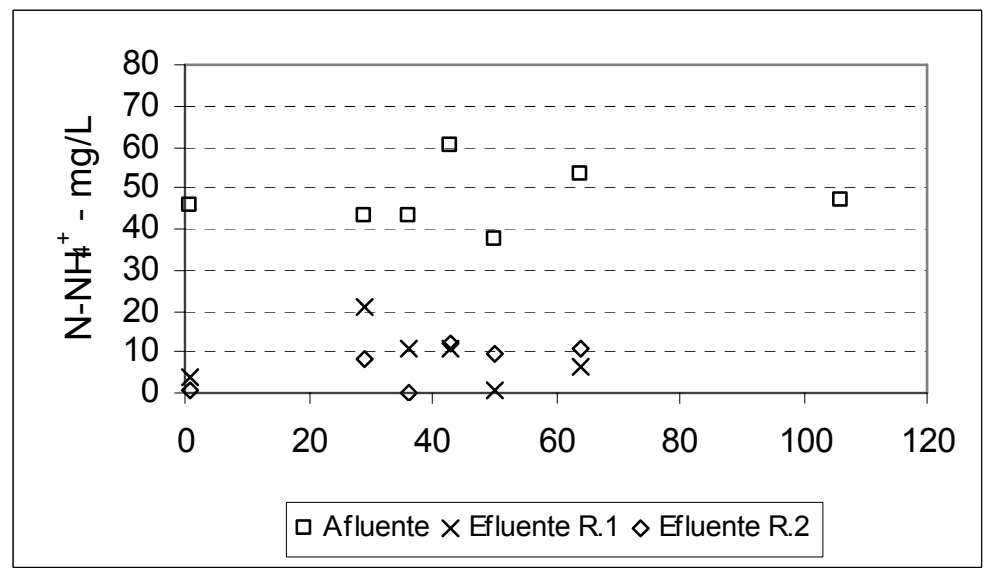

Figura 5.29 - Séries temporais de nitrogênio amoniacal dos esgotos afluente e efluente da ETE Juquitiba, após o início do lançamento do lodo da ETA no sistema de esgotos 
Na Tabela 5.16 verificou-se um valor da concentração de NKT do afluente o qual manteve-se dentro da faixa medida na situação anterior ao lançamento do lodo da ETA no sistema de esgoto (Tabela 5.9) e valores das concentrações de NKT dos efluentes na ordem de 2,4 vezes maior que os obtidos na situação anterior.

Para o nitrogênio amoniacal verificou-se uma concentração no afluente também na mesma faixa que aquela medida anteriormente e nos efluentes a concentração do nitrogênio amoniacal aumentou da situação antes para após o início do lançamento do lodo da ATA no sistema de esgotos na ordem de 4,7 vezes.

As Figuras 5.28 e 5.29 possibilitam verificar que as concentrações de NKT e dos efluentes dos reatores biológicos sofreram um aumento em relação ao período anterior.

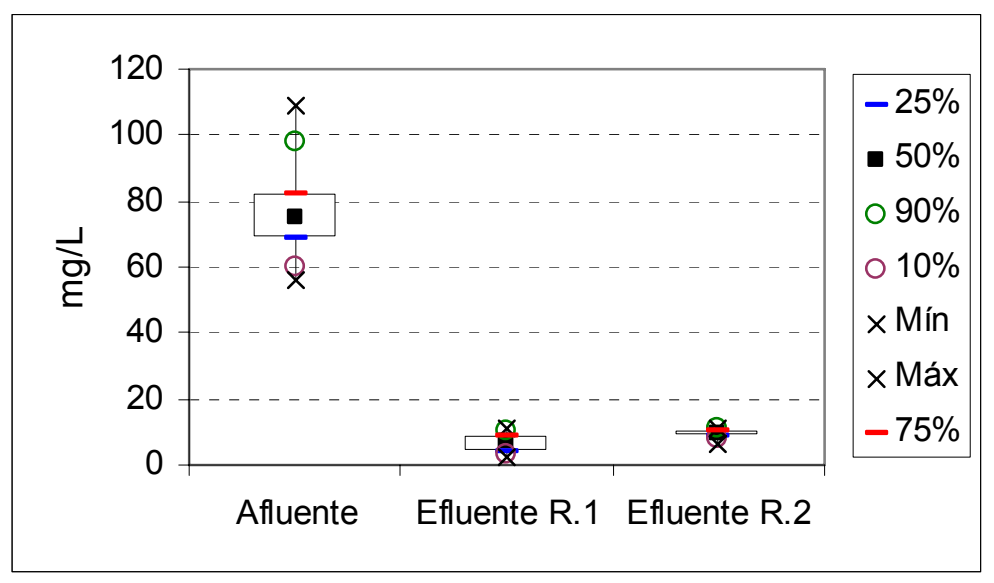

Figura 5.30 - Diagrama "Box-plot" de NKT do esgoto bruto e tratado da ETE Juquitiba, sem o lançamento do lodo da ETA no sistema de esgotos

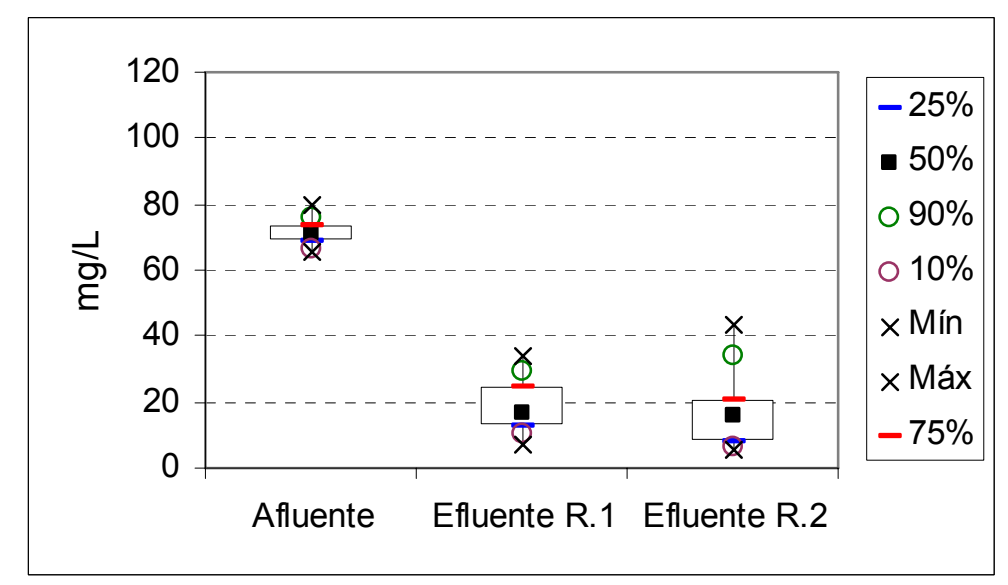

Figura 5.31 - Diagrama "Box-plot" de NKT do esgoto bruto e tratado da ETE Juquitiba, após o início do lançamento do lodo da ETA no sistema de esgotos 
Nas Figuras 5.30 e 5.31 verificou-se que houve uma diminuição da concentração de nitrogênio total Kjeldhal do esgoto bruto no segundo período. Verificou-se também que existiu o aumento da concentração de nitrogênio total nos efluentes da ETE no segundo período.

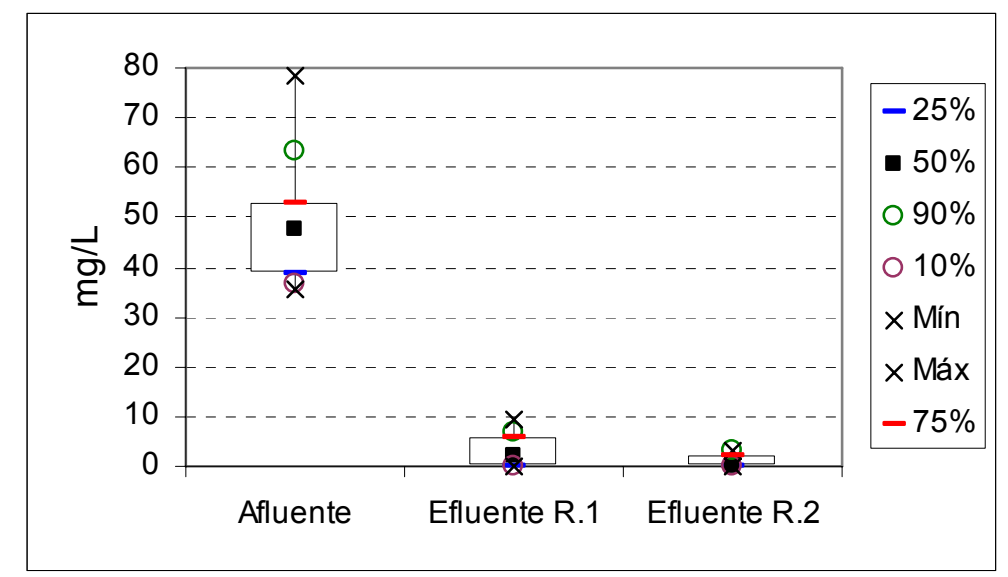

Figura 5.32 - Diagrama "Box-plot" de nitrogênio amoniacal do esgoto bruto e tratado da ETE Juquitiba, sem o lançamento do lodo da ETA no sistema de esgotos

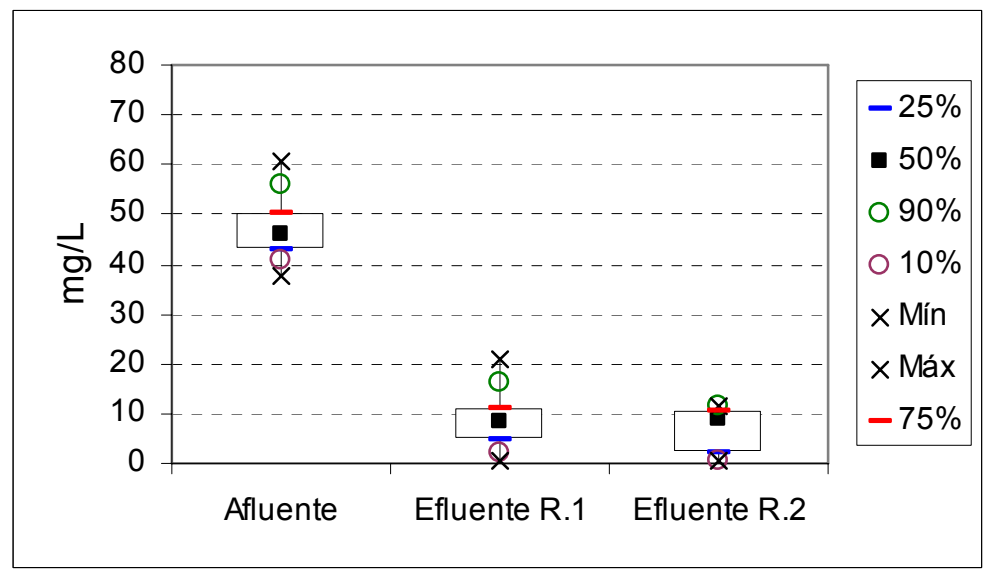

Figura 5.33 - Diagrama "Box-plot" de nitrogênio amoniacal do esgoto bruto e tratado da ETE Juquitiba, após o início do lançamento do lodo da ETA no sistema de esgotos

Nas Figuras 5.32 e 5.33 verificou-se que não houve alteração nas concentrações de nitrogênio amoniacal do esgoto bruto do primeiro para o segundo período. Porém verificou-se que existiu o aumento das concentrações de nitrogênio amoniacal dos efluentes da ETE após o início do lançamento do lodo da ETA no sistema de esgotos. 
Os parâmetros fósforo total e fósforo solúvel foram aqueles que apresentaram diferenças mais marcantes entre o primeiro período (antes do início do lançamento do lodo da ETA no sistema de esgotos) e o segundo período (após o início do lançamento do lodo da ETA no sistema de esgotos).

Tabela 5.17 - Resultados dos parâmetros fósforo total e solúvel do esgoto afluente e tratado da ETE Juquitiba, após o início do lançamento do lodo da ETA no sistema de esgotos

\begin{tabular}{ccccccc}
\hline Parâmetro & Ponto & $\mathrm{n}$ & Média & $\begin{array}{c}\text { Desvio } \\
\text { padrão }\end{array}$ & $\begin{array}{c}\text { Erro } \\
\text { padrão }\end{array}$ & $\begin{array}{c}\text { Intervalo de } \\
\text { confiança }(95 \%)\end{array}$ \\
\hline Fósforo Total $(\mathrm{mg} / \mathrm{L})$ & Afluente & 7 & 7,14 & 1,22 & 0,46 & {$[6,24 ; 8,04]$} \\
& Efluente R.1 & 6 & 2,12 & 0,68 & 0,47 & {$[1,20 ; 3,03]$} \\
& Efluente R.2 & 6 & 2,06 & 1,57 & 1,09 & {$[-0,08 ; 4,20]$} \\
Fósforo Solúvel (mg/L) & Afluente & 7 & 4,09 & 1,26 & 0,62 & {$[2,87 ; 5,31]$} \\
& Efluente R.1 & 6 & 0,55 & 0,49 & 0,66 & {$[-0,74 ; 1,85]$} \\
& Efluente R.2 & 7 & 0,54 & 1,01 & 1,37 & {$[-2,15 ; 3,23]$} \\
\hline
\end{tabular}

A concentração de fósforo total do esgoto bruto foi de 7,14 mg.P/L neste período pesquisado (Tabela 5.17) ante 8,92 mg.P/L encontrado no período anterior (Tabela 5.10), houve uma diminuição de $20 \%$ nesta concentração. A concentração de fósforo total obtida nos efluentes da estação após o lançamento do lodo da ETA na ETE foram 2,12 e 2,06 mg.P/L para os reatores 1 e 2 respectivamente. Foi verificado que ocorreu uma diminuição nas concentrações de fósforo total da situação antes para a situação depois do lançamento do lodo de ETA na ETE de $29 \%$ e $51 \%$ para os reatores 1 e 2 respectivamente.

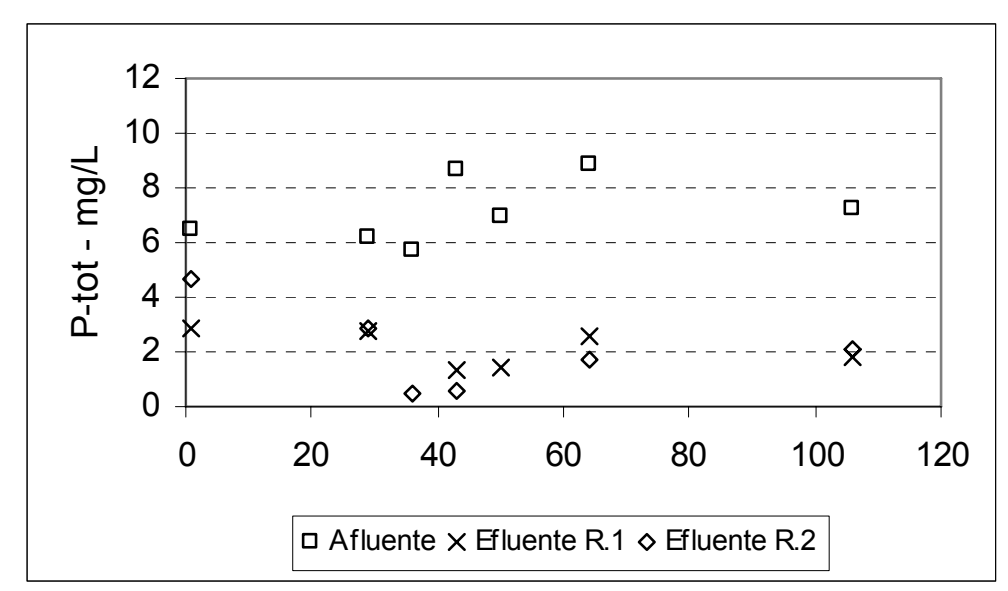

Figura 5.34 - Séries temporais de fósforo total do esgoto afluente e efluente da ETE Juquitiba, após o início do lançamento do lodo da ETA no sistema de esgotos 


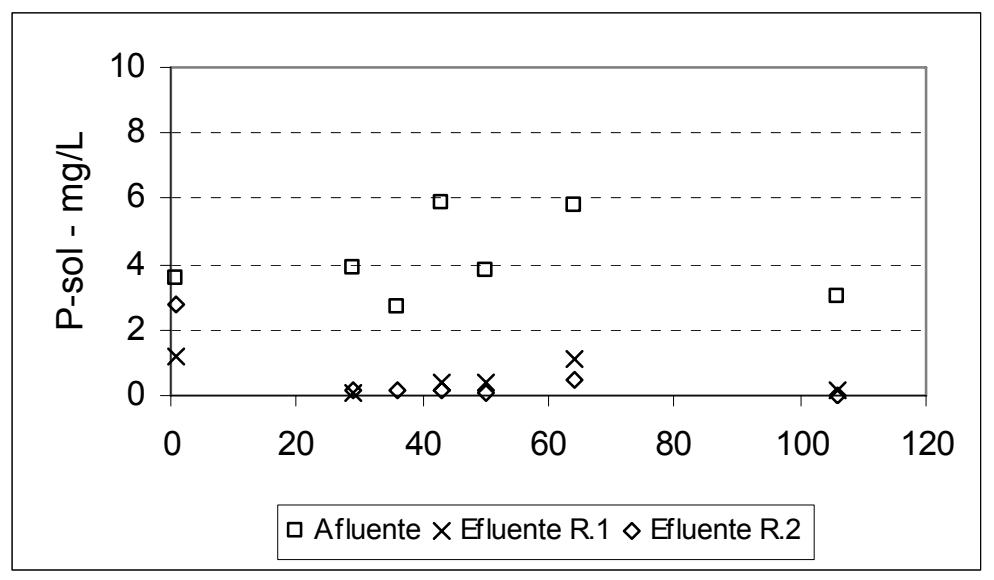

Figura 5.35 - Séries temporais de fósforo solúvel do esgoto afluente e efluente da ETE Juquitiba, após o início do lançamento do lodo da ETA no sistema de esgotos

O parâmetro fósforo solúvel apresentou resultados referentes a sua concentração no esgoto bruto de 4,09 mg.P/L neste segundo período (talbela 5.17) e uma concentração de 5,95 mg.P/L no período anterior (Tabela 5.10), verificando assim uma diminuição de $31 \%$ na concentração de fósforo solúvel nos esgotos após o lançamento do lodo de ETA na ETE via rede coletora de esgotos.

As concentrações de fósforo solúvel obtidas a partir dos efluentes dos reatores 1 e 2 após o início do lançamento do lodo da ETA na ETE foram 0,55 mg.P/L e 0,54 mg.P/L respectivamente. Comparandos com os valores obtidos antes do lançamento do lodo da ETA na ETE (Tabela 5.10), verificou que a concentração deste parâmetro no efluente diminuiu $74 \%$ para o reator 1 e $79 \%$ para o reator 2 após o início do lançamento do lodo de ETA no sistema de esgoto

As Figuras 5.34 e 5.35 ilustram a distribuição dos resultados ao longo do período pesquisado e nelas tem uma informação que chama a atenção: trata-se do primeiro dado de fósforo total e solúvel dos efluentes dos reatores 1 e 2.

Eles indicam concentrações iguais às médias dos resultados encontrados no período anterior e somente após este dia encontrou-se concentrações típicas deste segundo período. É importante lembrar que inicialmente o lançamento dos resíduos na rede coletora de esgotos se deu devido a lavagem dos filtros e a descarga rápida diária de fundo dos decantadores. A introdução deste resíduo nos reatores foi lenta e gradativa até que no dia 18 de agosto houve a primeira lavagem dos decantadores por completo com seus resíduos sendo lançados na rede coletora de esgotos. 


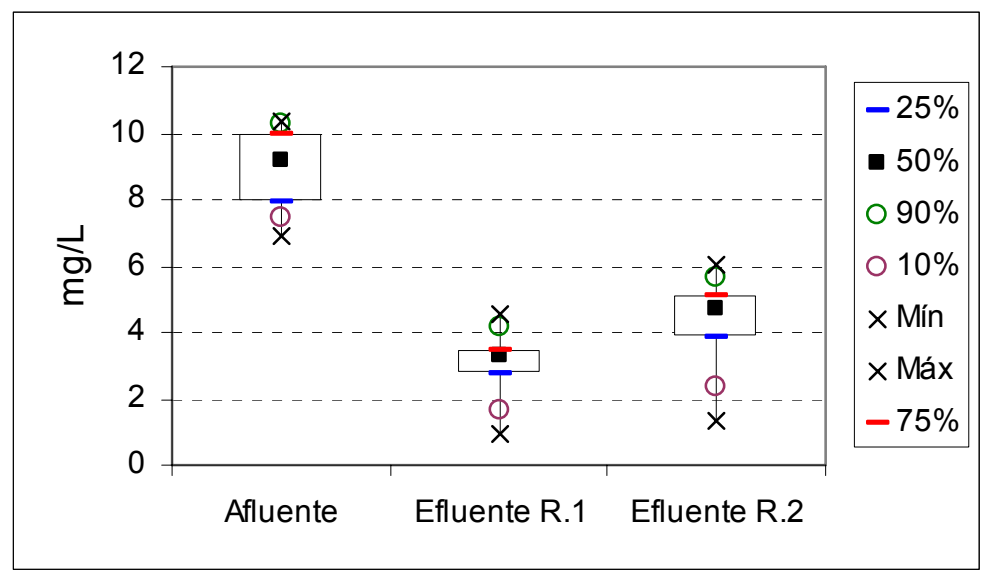

Figura 5.36 - Diagrama "Box-plot" de fósforo total do esgoto bruto e tratado da ETE Juquitiba, sem o lançamento do lodo da ETA no sistema de esgotos

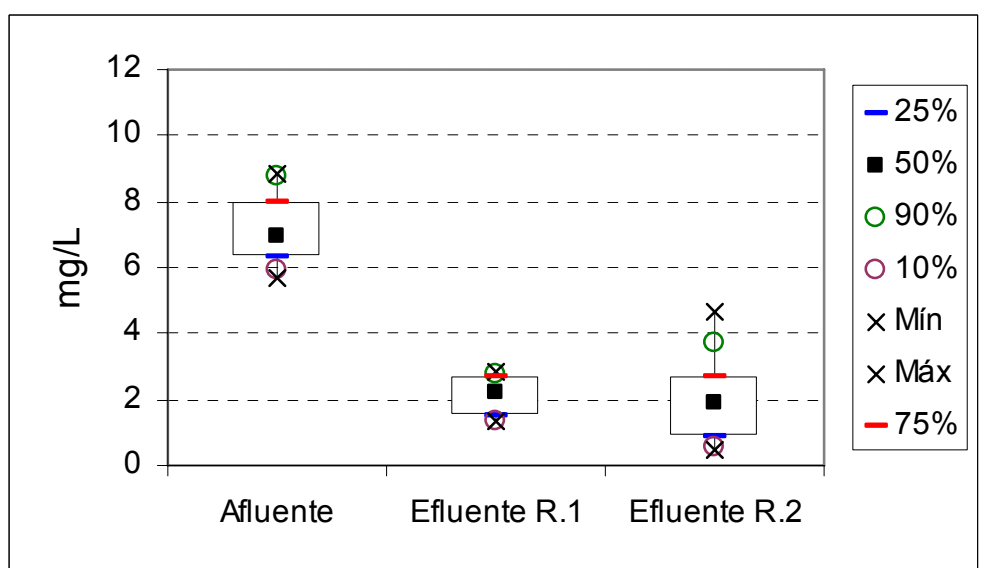

Figura 5.37 - Diagrama "Box-plot" de fósforo total do esgoto bruto e tratado da ETE Juquitiba, após o início do lançamento do lodo da ETA no sistema de esgotos

Nas Figuras 5.36 e 5.37 verificou-se a diminuição da concentração do fósforo total do esgoto bruto após o início do lançamento do lodo da ETA no sistema de esgotos. Verificou-se também a diminuição da concentração deste parâmetro nos efluentes dos reatores neste segundo período. 


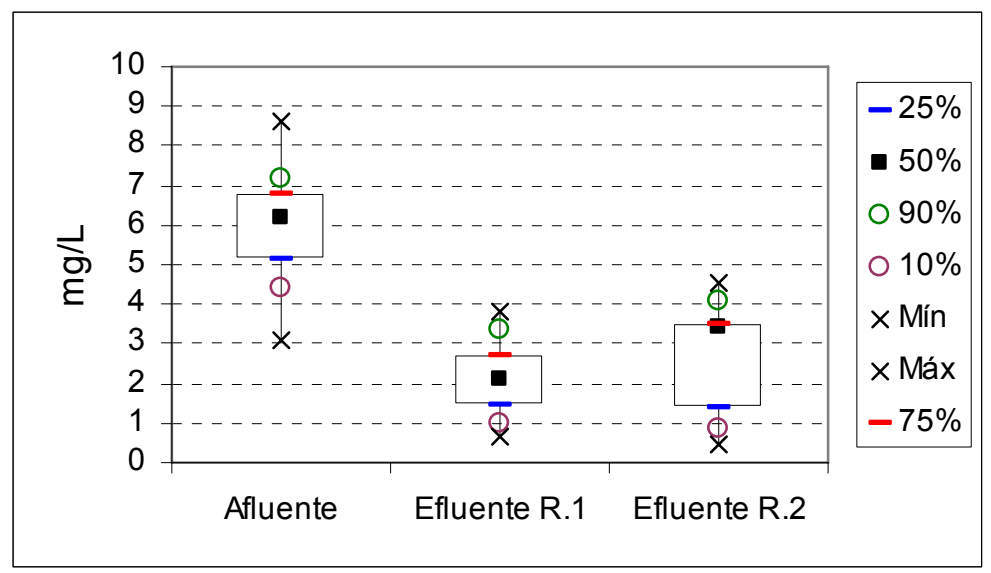

Figura 5.38 - Diagrama "Box-plot" de fósforo solúvel do esgoto bruto e tratado da ETE Juquitiba, sem o lançamento do lodo da ETA no sistema de esgotos

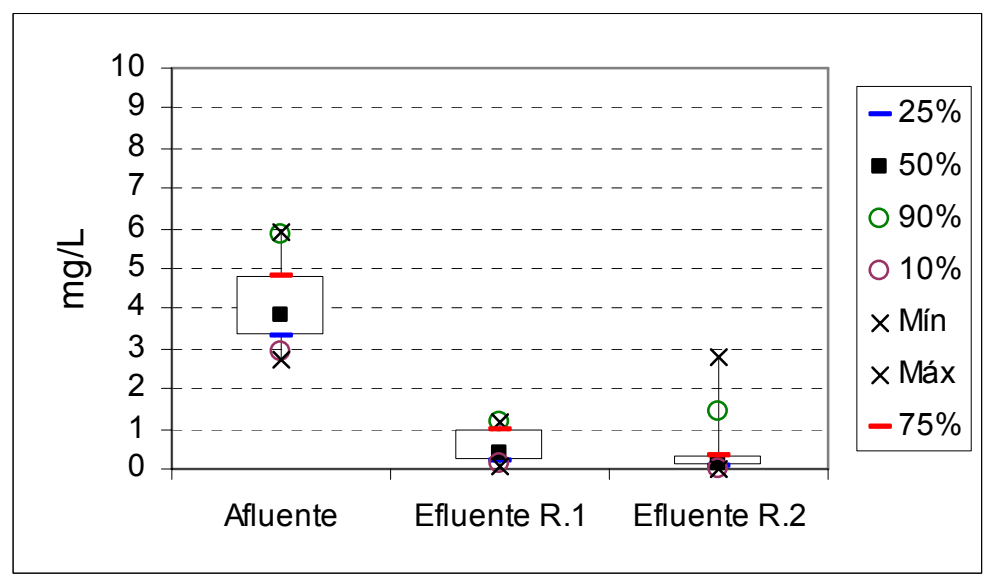

Figura 5.39 - Diagrama "Box-plot" de fósforo solúvel do esgoto bruto e tratado da ETE Juquitiba, após o início do lançamento do lodo da ETA no sistema de esgotos

Nas Figuras 5.38 e 5.39 verificou-se a diminuição da concentração do fósforo solúvel do esgoto bruto após o início do lançamento do lodo da ETA no sistema de esgotos. Verificou-se também a diminuição da concentração deste parâmetro nos efluentes dos reatores neste segundo período.

Tanto para o fósforo total, quanto para o fósforo solúvel, foi verificado a diminuição das concentrações no esgoto bruto e no efluente tratado. Para o esgoto bruto é importante ressalvar que além do caminhamento do lodo da ETA pela rede coletora de esgotos, existe uma estação elevatória de esgotos "final", antes destes chegarem à ETE, ou seja, todo esgoto que chega à ETE passa por esta elevatória tornando grande o contato do lodo da ETA com os esgotos antes de chegada na ETE. 
Tabela 5.18 - Resultados dos parâmetros oxigênio dissolvido, temperatura, pH e alcalinidade dos esgotos afluente, tratado e do lodo dos reatores biológicos da ETE Juquitiba, após o início do lançamento do lodo da ETA no sistema de esgotos

\begin{tabular}{ccccccc}
\hline Parâmetro & Ponto & $\mathrm{n}$ & Média & $\begin{array}{c}\text { Desvio } \\
\text { padrão }\end{array}$ & $\begin{array}{c}\text { Erro } \\
\text { padrão }\end{array}$ & $\begin{array}{c}\text { Intervalo de } \\
\text { confiança }(95 \%)\end{array}$ \\
\hline OD $(\mathrm{mg} / \mathrm{L})$ & Lodo R.1 & 5 & 3,95 & 2,36 & 1,19 & {$[1,63 ; 6,28]$} \\
& Lodo R.2 & 3 & 2,27 & 1,53 & 1,01 & {$[0,28 ; 4,26]$} \\
Temperatura $\left({ }^{\circ} \mathrm{C}\right)$ & Afluente & 4 & 19,50 & 3,00 & 0,68 & {$[18,17 ; 20,83]$} \\
& Lodo R.1 & 6 & 20,17 & 2,48 & 0,55 & {$[19,08 ; 21,25]$} \\
& Lodo R.2 & 6 & 21,17 & 2,32 & 0,50 & {$[20,18 ; 22,15]$} \\
& Efluente R.1 & 6 & 20,42 & 2,29 & 0,51 & {$[19,42 ; 21,41]$} \\
& Efluente R.2 & 5 & 19,80 & 2,05 & 0,46 & {$[18,90 ; 2,70]$} \\
& Afluente & 6 & 7,17 & 0,30 & 0,11 & {$[6,95 ; 7,39]$} \\
& Lodo R.1 & 5 & 6,67 & 0,20 & 0,08 & {$[6,51 ; 6,82]$} \\
& Lodo R.2 & 6 & 6,82 & 0,26 & 0,10 & {$[6,62 ; 7,01]$} \\
& Efluente R.1 & 6 & 6,73 & 0,23 & 0,09 & {$[6,55 ; 6,90]$} \\
& Efluente R.2 & 6 & 6,66 & 0,22 & 0,08 & {$[6,50 ; 6,83]$} \\
& Afluente & 7 & 188,29 & 27,04 & 1,97 & {$[184 ; 192]$} \\
& Efluente R.1 & 7 & 83,29 & 56,59 & 6,20 & {$[71,13 ; 95,44]$} \\
& Efluente R.2 & 7 & 67,31 & 36,49 & 4,45 & {$[58,60 ; 76,03]$} \\
\hline
\end{tabular}

Verificou-se com os dados da Tabela 5.18 que a concentração média de oxigênio dissolvido no lodo do reator biológico 1 foi igual à $3,95 \mathrm{mg} . \mathrm{OD} / \mathrm{L}$. Isto representa 1,12 vezes maior que a concentração obtida no mesmo reator no período anterior ao lançamento do lodo da ETA na ETE (Tabela 5.11). Já a concentração de OD no reator 2 obtida neste segundo período foi de $2,27 \mathrm{mg} . \mathrm{OD} / \mathrm{L}$, o mesmo parâmetro medido antes do lançamento do lodo da ETA na ETE foi de 2,68 $\mathrm{mg} . \mathrm{OD} / \mathrm{L}$, com isso verificou-se que houve uma redução de $15 \%$ de OD neste reator.

As temperaturas apresentaram um aumento da ordem de $2{ }^{\circ} \mathrm{C}$ neste segundo período, se comparado com os dados do primeiro período pesquisado. Foi verificada que ocorreu a manutenção do $\mathrm{pH}$ no sistema ao longo dos dois períodos, uma vez que os resultados obtidos nos primeiro e segundo períodos apresentam intersecções em todos respectivos intervalos de confiança.

A concentração de alcalinidade do esgoto bruto obtida após o lançamento do lodo da ETA no sistema de esgotos foi de $188,29 \mathrm{mg} / \mathrm{L}$ (Tabela 5.18) e a concentração medida antes disso foi de $211,88 \mathrm{mg} / \mathrm{L}$ (Tabela 5.11). Aparentemente ocorreu uma diminuição da concentração de alcalinidade no esgoto devido o contato 
com o lodo da ETA, porém deve ser considerado ao mesmo tempo ocorreu o aumento da vazão de esgoto (Tabela 5.13), seja pelo aporte de lodo de ETA no sistema, seja pela infiltração de água de chuva, as quais ocorreram com maior freqüência no segundo período. Em termos de massa, no período antes do lançamento do lodo da ETA no sistema de esgotos aplicou-se $73 \mathrm{Kg}$ de alcalinidade na ETE através do esgoto bruto e no período seguinte, aplicou-se $81 \mathrm{~kg}$ de alcalinidade na ETE.

Nos efluentes da ETE obtiveram-se as concentrações de alcalinidade de $51,88 \mathrm{mg} / \mathrm{L}$ e 60,38 mg/L para os reatores 1 e 2 respectivamente, após o lançamento do lodo da ETA na ETE (Tabela 5.18). Estes resultados são $60 \%$ e $11,5 \%$ maiores que aqueles obtidos antes do lançamento do lodo da ETA na ETE (Tabela 5.11), para os re atores 1 e 2 respectivamente.

Nesta etapa da pesquisa não foi realizada a comparação entre a variação de alcalinidade teórica e a variação real devido a falta dos dados de concentrações de nitrato.

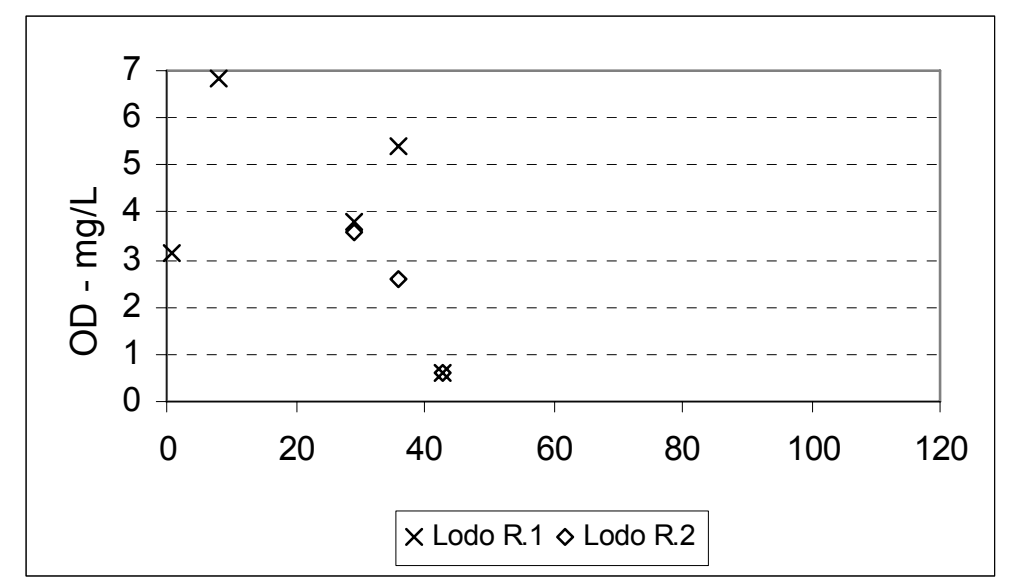

Figura 5.40 - Séries temporais de oxigênio dissolvido do lodo dos reatores 1 e 2 da ETE Juquitiba, apo o início do lançamento do lodo da ETA no sistema de esgotos 


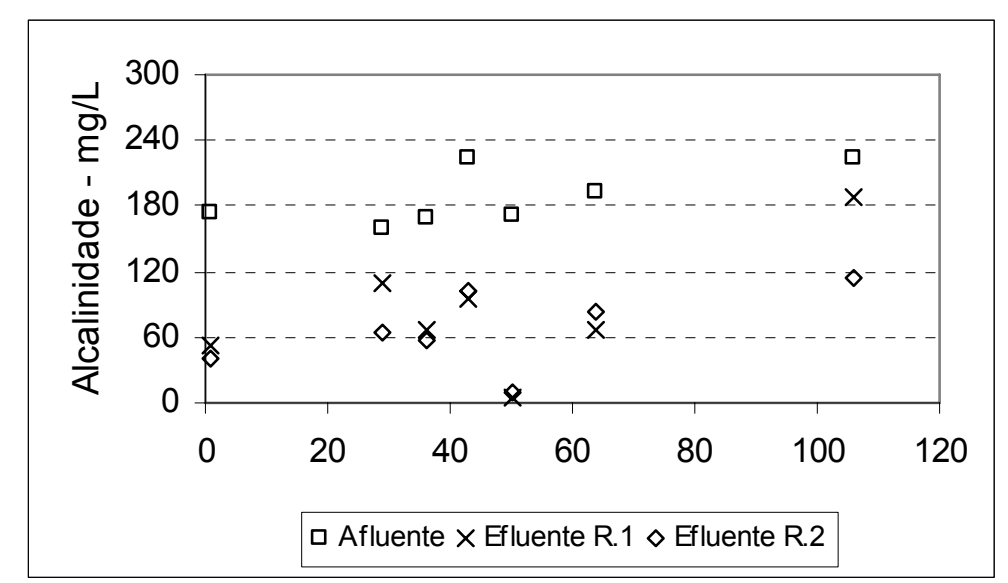

Figura 5.41 - Séries temporais de alcalinidade dos esgotos afluente e tratado da ETE Juquitiba, após o início do lançamento do lodo da ETA no sistema de esgotos

No dia 13 de setembro de 2006 encerrou-se a medição do oxigênio dissolvido nos reatores biológicos devido o encaminhamento do aparelho oxímetro para manutenção, chegou-se no final do período das análises sem o retorno do aparelho.

Quanto aos dados de alcalinidade, verificou-se uma pequena diminuição de sua concentração no esgoto bruto neste período (após o início do lançamento do lodo da ETA no sistema de esgotos) se comparado com o período anterior. Verificou-se o aumento de alcalinidade no efluente tratado da estação.

Tabela 5.19 - Eficiência obtida pela remoção dos parâmetros DBO5,20, DQO, nitrogênio total e amoniacal, fósforo total e solúvel do esgoto afluente e tratado da ETE Juquitiba, após o início do lançamento do lodo da ETA no sistema de esgotos

\begin{tabular}{ccccccc}
\hline Parâmetro & Ponto & $\mathrm{n}$ & Média & $\begin{array}{c}\text { Desvio } \\
\text { padrão }\end{array}$ & $\begin{array}{c}\text { Erro } \\
\text { padrão }\end{array}$ & $\begin{array}{c}\text { Intervalo de } \\
\text { confiança }(95 \%)\end{array}$ \\
\hline DBO5,20 & Efic R.1 (\%) & 5 & 83,78 & 7,63 & 0,83 & {$[82,15 ; 85,42]$} \\
& Efic R.2 (\%) & 3 & 84,64 & 6,36 & 0,69 & {$[83,29 ; 86,00]$} \\
DQO & Efic R.1 (\%) & 6 & 84,78 & 7,12 & 0,77 & {$[83,26 ; 86,29]$} \\
& Efic R.2 (\%) & 7 & 86,68 & 7,46 & 0,80 & {$[85,11 ; 88,25]$} \\
NKT & Efic R.1 (\%) & 7 & 73,07 & 14,07 & 1,65 & {$[69,84 ; 76,29]$} \\
& Efic R.2 (\%) & 5 & 73,78 & 20,35 & 2,37 & {$[69,13 ; 78,42]$} \\
N-amonia. & Efic R.1 (\%) & 6 & 81,03 & 16,86 & 1,87 & {$[77,35 ; 84,70]$} \\
& Efic R.2 (\%) & 6 & 85,64 & 10,86 & 1,17 & {$[83,35 ; 87,94]$} \\
Fósforo Total & Efic R.1 (\%) & 6 & 70,29 & 12,12 & 1,45 & {$[67,45 ; 73,12]$} \\
& Efic R.2 (\%) & 6 & 69,78 & 25,26 & 3,02 & {$[63,85 ; 75,70]$} \\
Fósforo Solúvel & Efic R.1 (\%) & 6 & 87,27 & 11,94 & 1,28 & {$[84,77 ; 89,78]$} \\
& Efic R.2 (\%) & 7 & 85,56 & 28,66 & 3,10 & {$[79,48 ; 91,63]$} \\
\hline
\end{tabular}




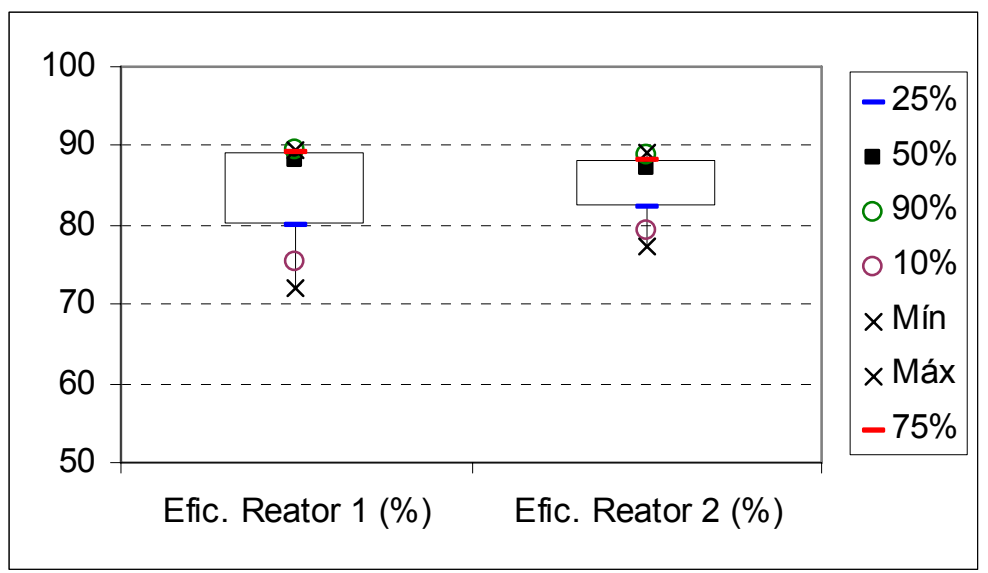

Figura 5.42 - Diagrama "box-plot" da eficiência de remoção de $\mathrm{DBO}_{5,20}$ do esgoto bruto pela ETE Juquitiba, após o início do lançamento do lodo da ETA no sistema de esgotos

Foi verificado na Tabela 5.19 que o sistema de tratamento atingiu a eficiência na remoção média de $83,78 \%$ de DBO para o reator 1 e $84,64 \%$ de DBO para o reator dois, após o início do lançamento da lodo da ETA no sistema de tratamento de esgotos. Quando comparado com as remoções atingidas pelo sistema antes do lançamento do lodo da ETA na ETE (Tabela 5.12), verificou-se a queda de $7 \%$ e $1 \%$ para os reatores 1 e 2 respectivamente.

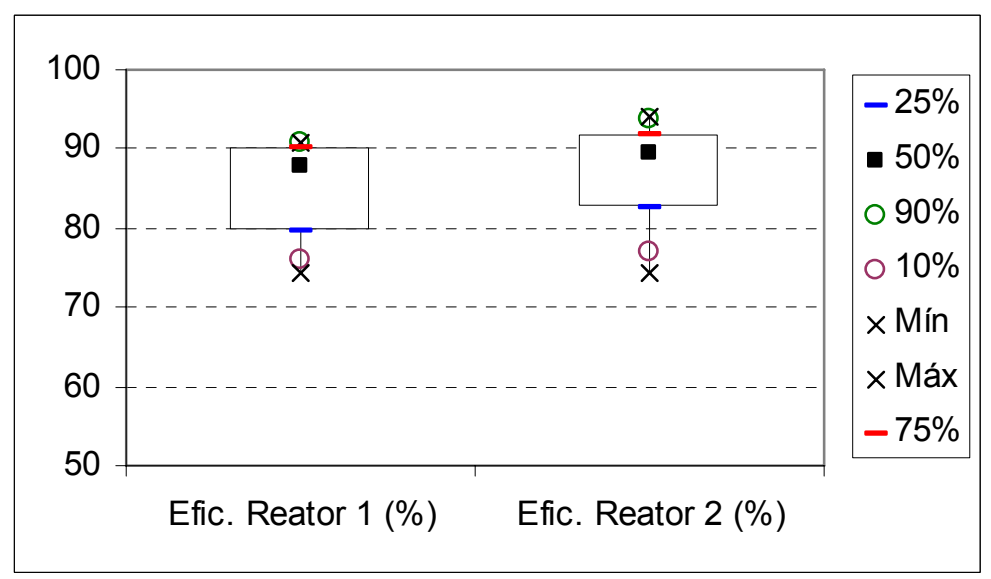

Figura 5.43 - Diagrama "box-plot" da eficiência de remoção de DQO do esgoto bruto pela ETE Juquitiba, após o início do lançamento do lodo da ETA no sistema de esgotos

Para as eficiências nas remoções de DQO pelos reatores 1 e 2 da ETE, verificaram-se as mesmas alterações ocorridas com a DBO, uma diminuição de $8 \%$ e $1 \%$ para os reatores 1 e 2 respectivamente, nas remoções ocorridas do primeiro pêra o segundo período pesquisado (Tabelas 5.12 e 5.19). 


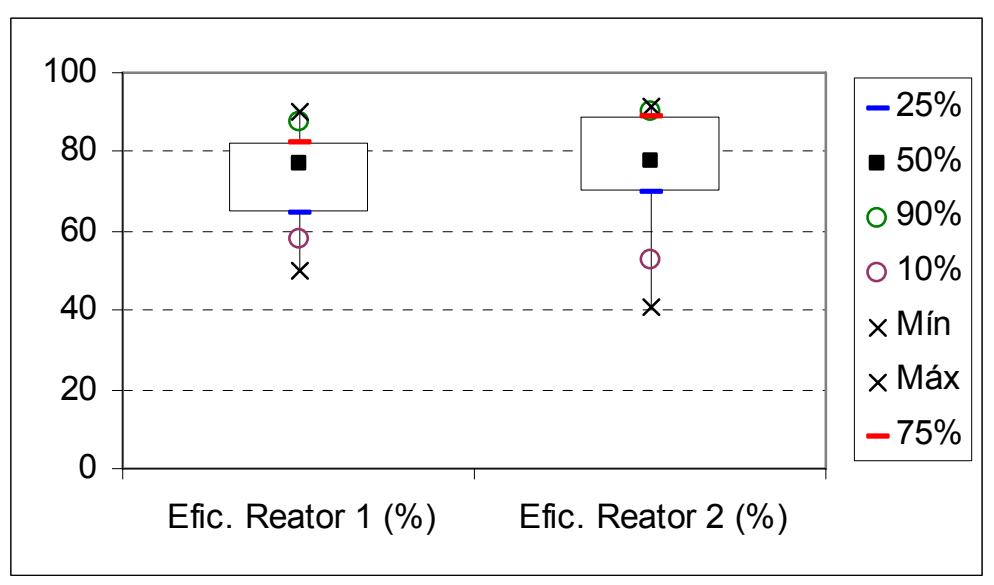

Figura 5.44 - Diagrama "box-plot" da eficiência de remoção de NKT do esgoto bruto pela ETE Juquitiba, após o início do lançamento do lodo da ETA no sistema de esgotos

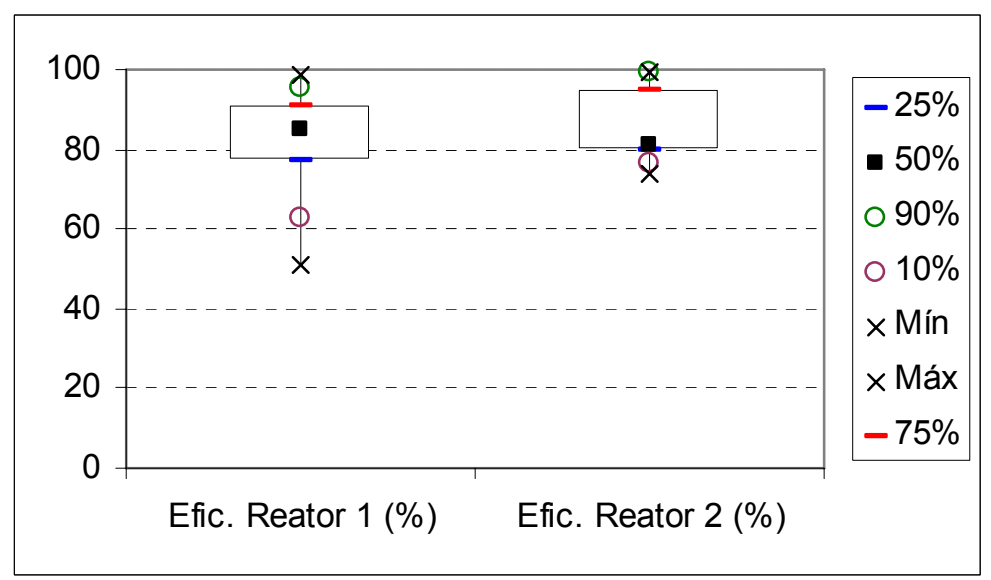

Figura 5.45- Diagrama "box-plot" da eficiência de remoção de nitrogênio amoniacal do esgoto bruto pela ETE Juquitiba, após o início do lançamento do lodo da ETA no sistema de esgotos

Nos diagramas das Figuras 5.44 e 5.45 verificou-se que houve a remoção de NKT e nitrogênio amoniacal do esgoto bruto pela ETE neste período, os quais apresentaram valores médios de $73 \%$ e $83 \%$ respectivamente (Tabela 5.19). Porém comparando com os dados de eficiência de remoção de $\mathrm{NKT}$ e $\mathrm{N}-\mathrm{NH}_{3}$ do período anterior (Tabela 5.12), verificou-se a diminuição média entre os dois reatores em $18 \%$ e 13\% respectivamente após o início do lançamento do lodo da ETA no sistema de esgotos. 


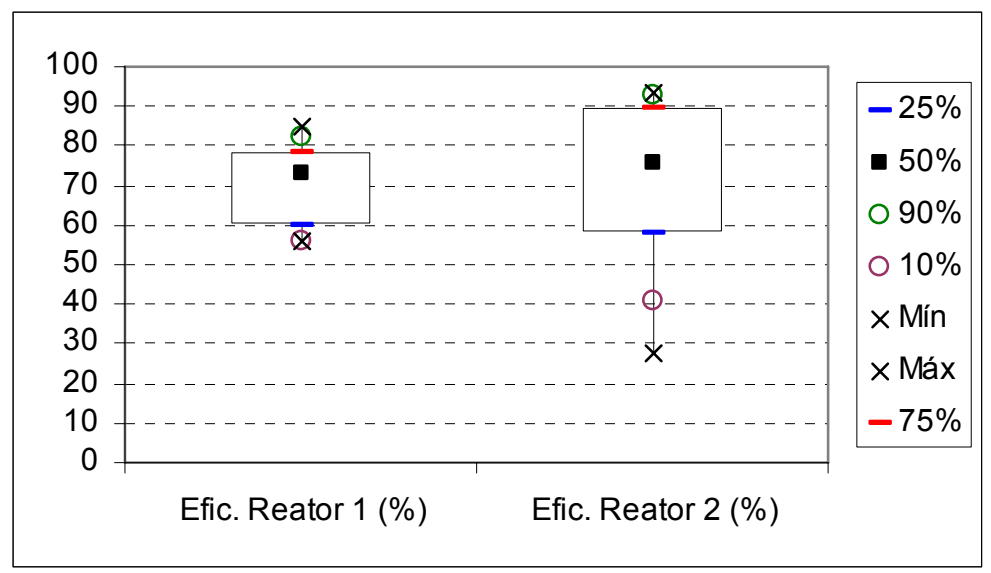

Figura 5.46 - Diagrama "box-plot" da eficiência de remoção de fósforo total do esgoto bruto pela ETE Juquitiba, após o início do lançamento do lodo da ETA no sistema de esgotos

Os resultados obtidos dos parâmetros fósforo total após o início do lançamento do lodo de ETA na ETE levaram à eficiência na remoção de $70 \%$ tanto para o reator 1 quanto para o reator 2 (Tabela 5.19). Quando comparado esta eficiência com aquelas obtidas antes do lançamento do lodo da ETA na ETE, 67\% e $52 \%$ de remoção de fósforo total para os re atores 1 e 2 respectivamente (Tabela 5.12), verificou-se um aumento na remoção de fósforo total em $6 \%$ para o reator 1 e $33 \%$ para o reator 2 .

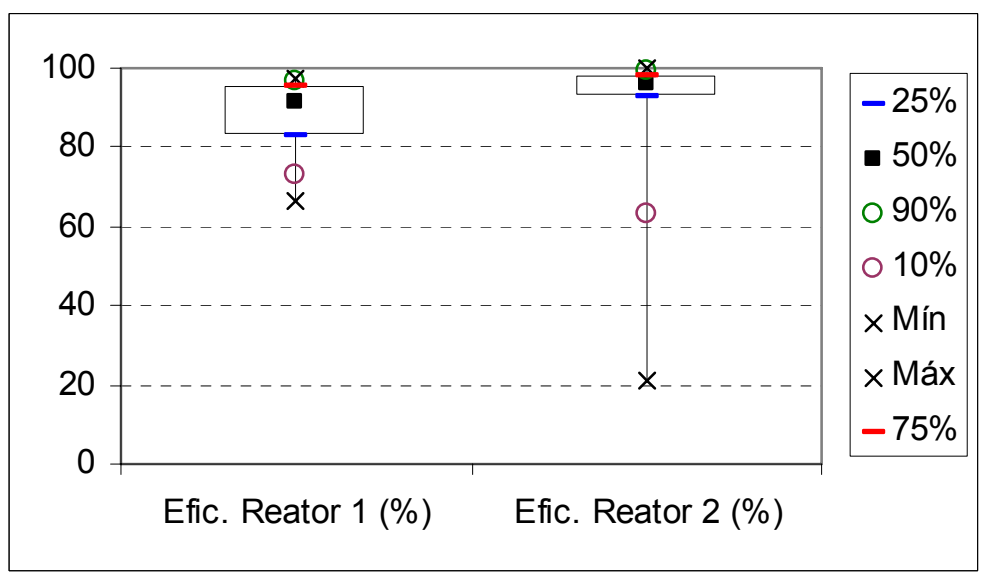

Figura 5.47 - Diagrama "box-plot" da eficiência de remoção de fósforo solúvel do esgoto bruto pela ETE Juquitiba, após o início do lançamento do lodo da ETA no sistema de esgotos

O parâmetro fósforo solúvel após o início do lançamento do lodo de ETA na ETE apresentou a eficiências na remoção de $86 \%$ para os reatores 1 e 2 (Tabela 5.19). Quando comparado este resultado com aqueles obtidos antes do lançamento 
do lodo da ETA na ETE, 66\% e 50 \% de remoção de fósforo solúvel para os reatores 1 e 2 respectivamente (Tabela 5.12), verificou-se um aumento na eficiência da remoção de fósforo total em $32 \%$ e $70 \%$ para os reatores 1 e 2 respectivamente. 


\section{6- Conclusões e recomendações}

1- A estação de tratamento de água objeto deste estudo atende a uma população quatro vezes maior que a estação de tratamento de esgoto. A ETA produz resíduos que resultariam em um acréscimo médio de $133 \mathrm{mg} / \mathrm{L}$ de sólidos no esgoto, porém, atingiu-se apenas um acréscimo médio de $74 \mathrm{mg} / \mathrm{L}$ de sólidos no esgoto devido à impossibilidade técnica de descarga total dos resíduos da ETA no sistema de esgotos. Ainda assim, tal contribuição representa, aproximadamente, uma situação em que o porte da ETA é o dobro da ETE receptora dos resíduos.

2- O processo de lodo ativado controlado pela idade do lodo de 25 dias trabalhava com a concentração média de $2600 \mathrm{mg} / \mathrm{L}$ de SST no reator 1 e $2850 \mathrm{mg} / \mathrm{L}$ de SST no reator 2 antes do aumento de iniciar o lançamento do lodo da ETA no sistema de esgotos. Após o início do lançamento do lodo da ETA no sistema de esgotos as concentrações de SST estabilizaram-se em 2850 e 3400 mg/L , respectivamente.

3- A produção de lodo de excesso no sistema de tratamento de esgoto aumentou em $40 \%$ em massa. Produzia-se $54,55 \mathrm{~kg}$ de sólidos por dia antes do lançamento do lodo da ETA no sistema de esgoto e, após, passou-se a produzir 77,1 $\mathrm{Kg}$ de sólidos por dia. Portanto, caso o porte da ETA fosse da mesma ordem de grandeza do porte da ETE, o acréscimo na produção de lodo a ser descartado seria de $20 \%$, aproximadamente.

4- As eficiências de remoção dos parâmetros DBO e DQO mostraram-se 4\%, em média, menores após o lançamento do lodo da ETA no sistema de esgotos.

5- As concentrações de sólidos em suspensão totais do efluente final sofreu um aumento de $73 \%$ após o início do lançamento do lodo da ETA no sistema de esgotos. Apesar de que apresentaram valores pequenos em ambas as situações: 41 mg.SST/L antes e $67 \mathrm{mg} . \mathrm{SST} / \mathrm{L}$ após o lançamento do lodo da ETA no sistema de esgotos. 
6- O lançamento do lodo da ETA no sistema de esgoto implicou na diminuição da remoção média de $\mathrm{NKT}$ em $18 \%$ e na remoção média de $\mathrm{N}-\mathrm{NH}_{3}$ em $13 \%$. Antes deste lançamento, o sistema removia $96 \%$ de amônia e passou a remover, após o lançamento $83 \%$.

7- A concentração de fósforo total no esgoto bruto apresentou uma diminuição de $20 \%$ e a concentração de fósforo solúvel, uma diminuição de $31 \%$ com o lançamento do lodo da ETA no sistema de esgotos. Além do efeito de diluição, pode ter ocorrido alguma forma de interação entre o lodo da ETA e o fósforo solúvel.

8- Ocorreu uma diminuição nas concentrações de fósforo total do efluente dos reatores 1 e 2 da situação antes para a situação depois do lançamento do lodo de ETA no sistema de esgotos (de $29 \%$ e $51 \%$, respectivamente).

9- Ocorreu uma diminuição nas concentrações de fósforo solúvel do efluente dos reatores 1 e 2 da situação antes para a situação depois do lançamento do lodo de ETA no sistema de esgotos (de $74 \%$ e $79 \%$, respectivamente).

10- Como conclusão final, pode ser dito que os sistemas de tratamento de esgotos pelo processo de lodo ativado com aeração prolongada operando sob o regime de bateladas seqüenciais são adequados para o recebimento de lodo proveniente de estações de tratamento de água, desde que seja projetada para atender a essa função complementar, especialmente no que se refere às unidades de desidratação de lodo.

Recomenda-se que estudos semelhantes sejam conduzidos com a descarga de lodo de estação de tratamento de água em estações de tratamento de esgoto por outros processos. Recomenda-se adicionalmente que os efeitos sobre as transformações do nitrogênio nos reatores biológicos e os efeitos sobre a remoção de fósforo sejam avaliados de forma mais pormenorizada. 


\section{REFERÊNCIAS}

ASSOCIAÇÃO BRASILEIRA DE NORMAS TÉCNICAS. NBR - 10.004. Resíduos Sólidos, ABNT, São Paulo, 1987.

AMERICAN PUBLIC HEALTH ASSOCIATION. American Water Works Association. Water Environment Federation. Standard methods for the examination of water and wastewater. 18. ed. Washington, DC: American Public Health Association, 1995. $1268 \mathrm{p}$.

AMERICAN SOCIETY OF CIVIL ENGINEERS. American Water Works Association. Management of water treatment plant residuals: technology transfer handbook. New York, N.Y.; Denver, CO: American Society of Civil Engineers: American Water Works Association, c1996. xxv, 294 p. (ASCE manuals and reports of engineering practice, n. 88).

AMERICAN WATER WORKS ASSOCIATION RESEARCH FOUNDATION. Slib, schlamm, sludge. Denver, CO; [Nieuwegein, Netherlands]: AWWA Research Foundation: Keuringsinstituut voor Waterleidingartikelen, 1990. vii, 308 p.

ANDREOLI, C. V. (Coord.). Resíduos sólidos do saneamento: processamento, reciclagem e disposição final. Rio de Janeiro: Rima, ABES, 2001. xxiv, 257 p. (Projeto PROSAB).

. Lodo de esgotos: tratamento e disposição final. Belo Horizonte; Curitiba: DESA/UFMG: SANEPAR, 2001. 483 p.

ASSOCIAÇÃO BRASILEIRA DE NORMAS TÉCNICAS. NBR 10.004: resíduos sólidos. São Paulo, 1987. 62 p.

BRASIL. Ministério do Meio Ambiente. Conselho Nacional do Meio Ambiente. Resolução no 357, de 17 de março de 2005. Dispõe sobre a classificação dos corpos de água e diretrizes ambientais para o seu enquadramento, bem como estabelece as condições e padrões de lançamento de efluentes, e dá outras providências. Diário Oficial da União, Brasília, 17 mar. 2005.

CARVALHO, E. H. de. Disposição de resíduos gerados nas estações de tratamento de água em estações de tratamento de esgoto com decantação primária. 2000. 171 f. Tese (Doutorado) - Escola de Engenharia de São Carlos, Universidade de São Paulo, São Carlos, 2000.

CINTRA FILHO, O. A. O gerenciamento de iodo de ETA no município de Franca. In: WORKSHOP: QUALIDADE DA ÁGUA E O GERENCIAMENTO DE LODO DE 
ETA'S, 3., 2004, São Paulo. Anais... São Paulo: Instituto de Pesquisas Energéticas e Nucleares, 2004.

COMPANHIA DE SANEAMENTO BÁSICO DE SÃO PAULO. Diretoria de Sistemas Regionais. Superintendência de Gestão e Desenvolvimento Operacional de Sistemas Regionais. Departamento de Controle Sanitário e Ambiental. Tratamento e disposição final do lodo de estação de tratamento de água. São Paulo, 2003.(Relatório interno).

CORDEIRO, J. S. O problema do lodo gerado em decantadores de estações de tratamento de água. 1993 Tese (Doutorado) - Escola Engenharia de São Carlos, Universidade de São Paulo, São Carlos, 1993.

CORNWELL, D. A. et al. Water treatment plant waste management. Denver, Co.: AWWA Research Foundation, 1987. xx, 459 p.

DI BERNARDO, L. Métodos e técnicas de tratamento de água. Rio de Janeiro: ABES, 1993. 2 v.

ENVIRONMENTAL PROTECTION AGENCY. Center for Environmental Research Information. Sequencing batch reactors: summary report. Cincinnati; EPA; 1986. 23 p. (EPA/625/8-86/011).

FERREIRA FILHO, S. S. Concepção de ETA e produção de lodo I. São Paulo: EPUSP, 2005. Material de aula. Departamento de Hidráulica e Sanitária da Escola Politécnica da Universidade de São Paulo.

; ALEM SOBRINHO, P. Considerações sobre o tratamento de despejos líquidos gerados em estações de tratamento de água. Engenharia Sanitária e Ambiental, Rio de Janeiro, v. 3, n. 3/4, p. 128-136, jul/dez. 1998.

JANUÁRIO, G. F. Planejamento e aspectos ambientais envolvidos na disposição final de lodos de estações de tratamento de água da região metropolitana de São Paulo. 2005. 222 f. Dissertação (Mestrado) - Escola Politécnica, Universidade de São Paulo, São Paulo, 2005.

JORDÃO, E. P.; PESSOA, C. A. Tratamento de esgotos domésticos. 4. ed. Rio de Janeiro: Associação Brasileira de Engenharia Sanitária e Ambiental, 2005. 932 p. 
MAGALHÃES, M. N. Noções de probabilidade e estatística. 6. ed. São Paulo: EDUSP, 2005. 392 p.

METCALF \& EDDY. Wastewater engineering: treatment and reuse. $4^{\text {th }}$ ed. Boston; London: McGraw-Hill, c2003. xxviii, 1819 p.

PARSEKIAN, M. P. S. Análise e proposta de formas de gerenciamento de estações de tratamento de água de abastecimento. 1998. 183 f. Dissertação (Mestrado) - Escola de Engenharia de São Carlos, Universidade de São Paulo, São Carlos, 1998.

PIVELI, R. P. Qualidade das águas e poluição: aspectos físico-químicos. São Paulo: ABES, 2005. 285 p.

REALI, M. A. P. (Coord.). Noções gerais de disposição final de lodo de estações de tratamento de água. Rio de Janeiro: PROSAB, c1999. xiv, 225 p.

REIS, E. L. T.; COTRIM, M. E.; FILHO, O. B.; SOUZA, A. L. F.; AMALFI, P. Z.; RODRIGUES, C.; PIRES, M. A. F. Sludge characterization from a water treatment plant on Ribeira do Iguape river by inductively coupled plasma optical emissiom Spectrometry Proceedings: $8^{\mathrm{TH}}$, Rio Symposium om Atomic Spectrometry, Parati, RJ. Ago, 2004.

REIS, E. L. T. Abordagem Sistêmica do Sistema de Tratamento de Água de Registro, São Paulo, com Ênfase na Avaliação do Impacto do Descarte dos Resíduos na Bacia Hidrográfica do Rio Ribeira de Iguape. Tese (Doutorado) IPEN/USP, 2005.

SCALIZE, P. S. Disposição de resíduos gerados em estações de tratamento de água em estações de tratamento de esgoto. 2003. $146 \mathrm{f}$. Tese (Doutorado) Escola de Engenharia de São Carlos, Universidade de São Paulo, São Carlos, 2003.

SISTEMA NACIONAL DE INFORMAÇÕES SOBRE SANEAMENTO. Visão geral da prestação de serviços de água e esgotos- 2002: um extrato do diagnóstico dos serviços de água e esgotos. Brasília: Programa de Modernização do Setor Saneamento, 2004. Disponível em: <http://www.snis.gov.br/visao 2002.htm>.

VAN HAANDEL, A.; MARAIS, G. O comportamento do sistema de lodo ativado: teoria e aplicações para projeto e operações. Campina Grande, PB: Universidade Federal da Paraíba, 1999. 472 p. 
VAZOLLER, R. F. Microbiologia de lodos ativados. São Paulo: CETESB, 1989. 23 p. (Série manuais. Secretaria do Meio Ambiente).

VON SPERLING, M. Introdução à qualidade das águas e ao tratamento de esgotos. 2. ed. rev. Belo Horizonte: DESA/UFMG, 1996. v. 1.

. Lodos ativados: princípios do tratamento biológico de águas residuárias. 2. ed. ampl. Belo Horizonte: DESA/UFMG, 2002. v. 4. 


\section{Anexo1 - Dados das caracterizações físico-quimicas}

\begin{tabular}{|c|c|c|c|}
\hline & $\overline{\mathrm{DBO}}$ & & \\
\hline Data & Afluente & Efluente R.1 & Efluente R.2 \\
\hline \multicolumn{4}{|l|}{$24 / 5 / 2006$} \\
\hline $31 / 5 / 2006$ & 551 & & 115 \\
\hline $7 / 6 / 2006$ & 420 & & 18 \\
\hline $14 / 6 / 2006$ & 491 & 44 & 21 \\
\hline $21 / 6 / 2006$ & 354 & & 71 \\
\hline $28 / 6 / 2006$ & 277 & 49 & 58 \\
\hline $5 / 7 / 2006$ & 364 & 41 & 70 \\
\hline $12 / 7 / 2006$ & 259 & 12 & 57 \\
\hline $19 / 7 / 2006$ & 312 & 17 & \\
\hline \multirow[t]{2}{*}{$26 / 7 / 2006$} & 296 & & 54 \\
\hline & DQO & & \\
\hline Data & Afluente & Efluente R.1 & Efluente R.2 \\
\hline $24 / 5 / 2006$ & 733 & 28 & 40 \\
\hline $31 / 5 / 2006$ & 700 & & 101 \\
\hline $7 / 6 / 2006$ & 900 & & 160 \\
\hline $14 / 6 / 2006$ & 875 & 65 & 61 \\
\hline $21 / 6 / 2006$ & 646 & & 93 \\
\hline $28 / 6 / 2006$ & 545 & 103 & 111 \\
\hline $5 / 7 / 2006$ & 893 & 58 & 166 \\
\hline $12 / 7 / 2006$ & 714 & 20 & 64 \\
\hline $19 / 7 / 2006$ & 634 & & \\
\hline $26 / 7 / 2006$ & 543 & & 48 \\
\hline
\end{tabular}




\begin{tabular}{ccc}
\hline \multicolumn{3}{c}{ OD } \\
\hline Data & Lodo R.1 & Lodo R.2 \\
$24 / 5 / 2006$ & & \\
$31 / 5 / 2006$ & & \\
$7 / 6 / 2006$ & & 1,2 \\
$14 / 6 / 2006$ & 0,79 & 2,91 \\
$21 / 6 / 2006$ & 2,2 & 3,2 \\
$28 / 6 / 2006$ & 2,8 & 5,12 \\
$5 / 7 / 2006$ & & \\
$12 / 7 / 2006$ & 1,61 & 2,49 \\
$19 / 7 / 2006$ & & \\
$26 / 7 / 2006$ & 1,9 & 1,15 \\
\hline
\end{tabular}

\begin{tabular}{|c|c|c|c|c|}
\hline \multicolumn{5}{|c|}{ Temperatura } \\
\hline Data & Afluente & Lodo 1 & Lodo 2 & Efluente R.1 \\
\hline \multicolumn{5}{|l|}{$24 / 5 / 2006$} \\
\hline \multicolumn{5}{|l|}{$31 / 5 / 2006$} \\
\hline \multicolumn{5}{|l|}{$7 / 6 / 2006$} \\
\hline $14 / 6 / 2006$ & & & 18,7 & 18,7 \\
\hline $21 / 6 / 2006$ & & 18,5 & 18 & 18,1 \\
\hline $28 / 6 / 2006$ & & 16 & 16,4 & 16,4 \\
\hline $5 / 7 / 2006$ & & 17 & 18 & 20 \\
\hline $12 / 7 / 2006$ & 19,5 & 19,5 & & 20 \\
\hline $19 / 7 / 2006$ & 18 & 18 & & \\
\hline $26 / 7 / 2006$ & 17 & & 18 & \\
\hline
\end{tabular}

$\mathrm{pH}$

\begin{tabular}{cccccc}
\hline $\begin{array}{c}\text { Data } \\
24 / 5 / 2006\end{array}$ & Afluente & Lodo 1 & Lodo 2 & Efluente R.1 & Efluente R.2 \\
$31 / 5 / 2006$ & 7,39 & 6,48 & 7,2 & 6,47 & 7,06 \\
$7 / 6 / 2006$ & & & & & \\
$14 / 6 / 2006$ & 7 & 6,28 & 5,7 & 6,9 & 6,62 \\
$21 / 6 / 2006$ & 7,1 & 6,2 & 6,61 & 6,7 & 6,67 \\
$28 / 6 / 2006$ & 7,01 & 6,1 & 6,42 & 6,8 & 6,9 \\
$5 / 7 / 2006$ & 7,23 & 6,88 & 6,74 & 6,77 & 6,76 \\
$12 / 7 / 2006$ & 6,74 & 6,97 & 6,9 & 6,68 & 6,6 \\
$19 / 7 / 2006$ & 6,9 & 6,5 & & & 7 \\
$26 / 7 / 2006$ & 7,08 & 6,9 & 6,6 & 6,91 & 6,92 \\
\hline
\end{tabular}




\begin{tabular}{cccc}
\hline \multicolumn{3}{c}{ Alcalinidade } & \\
\hline Data & Afluente & Efluente & Efluente R.2 \\
$24 / 5 / 2006$ & 188 & 21 & 39 \\
$31 / 5 / 2006$ & 167 & 99 & 148 \\
$7 / 6 / 2006$ & & & \\
$14 / 6 / 2006$ & 220 & 56 & 73 \\
$21 / 6 / 2006$ & 256 & 46 & 33 \\
$28 / 6 / 2006$ & 195 & 42 & 37 \\
$5 / 7 / 2006$ & 302 & 41 & 44 \\
$12 / 7 / 2006$ & 227 & 53 & 54 \\
$19 / 7 / 2006$ & & & \\
$26 / 7 / 2006$ & 140 & 57 & 55 \\
\hline
\end{tabular}

SST

\begin{tabular}{|c|c|c|c|c|c|}
\hline Data & Afluente & Lodo R.1 & Lodo R.2 & Efluente R.1 & Efluente R.2 \\
\hline $24 / 5 / 2006$ & 352 & & 2676 & 20 & 28 \\
\hline $31 / 5 / 2006$ & 240 & 2760 & & & 32 \\
\hline $7 / 6 / 2006$ & 332 & 1912 & & & 28 \\
\hline $14 / 6 / 2006$ & 360 & 2036 & & 32 & 16 \\
\hline $21 / 6 / 2006$ & 360 & 2148 & & & 60 \\
\hline $28 / 6 / 2006$ & & 3036 & 2796 & 120 & 68 \\
\hline $5 / 7 / 2006$ & 352 & 2768 & 2416 & 36 & 84 \\
\hline $12 / 7 / 2006$ & 200 & 3100 & 2940 & 16 & 44 \\
\hline $19 / 7 / 2006$ & 276 & 2964 & 3220 & 8 & \\
\hline \multirow[t]{2}{*}{$26 / 7 / 2006$} & 452 & 2700 & 3040 & & 44 \\
\hline & SSV & & & & \\
\hline Data & Afluente & Lodo R.1 & Lodo R.2 & Efluente R.1 & Efluente R.2 \\
\hline $24 / 5 / 2006$ & 300 & & 2016 & 20 & 24 \\
\hline $31 / 5 / 2006$ & 208 & 2040 & & & 32 \\
\hline $7 / 6 / 2006$ & 280 & 1444 & & & 28 \\
\hline $14 / 6 / 2006$ & 300 & 1548 & & 32 & 16 \\
\hline $21 / 6 / 2006$ & 300 & 1608 & & & 60 \\
\hline $28 / 6 / 2006$ & & 2032 & 2224 & 80 & 48 \\
\hline $5 / 7 / 2006$ & 296 & 1760 & 1932 & 32 & 76 \\
\hline $12 / 7 / 2006$ & 160 & 1760 & 2060 & 4 & 36 \\
\hline $19 / 7 / 2006$ & 224 & 1816 & 2196 & 8 & \\
\hline $26 / 7 / 2006$ & 308 & 1852 & 2148 & & 36 \\
\hline
\end{tabular}




\begin{tabular}{cccccc}
\hline Data & SSF & & & & \\
Afluente & Lodo R.1 & Lodo R.2 & Efluente R.1 Efluente R.2 \\
$24 / 5 / 2006$ & 52 & & 660 & 4 \\
$31 / 5 / 2006$ & 32 & 720 & & & \\
$7 / 6 / 2006$ & 52 & 468 & & & \\
$14 / 6 / 2006$ & 60 & 488 & & & \\
$21 / 6 / 2006$ & 60 & 540 & & & 8 \\
$28 / 6 / 2006$ & & 1004 & 572 & & 8 \\
$5 / 7 / 2006$ & 56 & 1008 & 484 & 4 & \\
$12 / 7 / 2006$ & 40 & 1340 & 880 & 12 & 8 \\
$19 / 7 / 2006$ & 52 & 1148 & 1024 & & \\
$26 / 7 / 2006$ & 144 & 848 & 892 & & \\
\hline
\end{tabular}

\begin{tabular}{|c|c|c|c|}
\hline & $\begin{array}{c}\text { Nitrogênio } \\
\text { Total }\end{array}$ & & \\
\hline Data & Afluente & Efluente R.1 & Efluente R.2 \\
\hline $24 / 5 / 2006$ & 75 & & \\
\hline $31 / 5 / 2006$ & 60,5 & & \\
\hline $7 / 6 / 2006$ & 84 & & \\
\hline $14 / 6 / 2006$ & 75,6 & 11,4 & \\
\hline $21 / 6 / 2006$ & 96,32 & & 8,96 \\
\hline $28 / 6 / 2006$ & 72,24 & 8,96 & 10,64 \\
\hline $5 / 7 / 2006$ & 109,2 & 7,28 & 11,2 \\
\hline $12 / 7 / 2006$ & 77,84 & 3,9 & 6,7 \\
\hline $19 / 7 / 2006$ & 67,76 & 2,24 & \\
\hline $26 / 7 / 2006$ & 56 & & 9,5 \\
\hline
\end{tabular}

\begin{tabular}{cccc}
\hline \multicolumn{4}{c}{ N-Amoniacal } \\
\hline Data & Afluente & Efluente R.1 & Efluente R.2 \\
$24 / 5 / 2006$ & 39 & 0 & 0 \\
$31 / 5 / 2006$ & 36,4 & 4,8 & \\
$7 / 6 / 2006$ & 52,64 & 9,52 & \\
$14 / 6 / 2006$ & 49,2 & 6,1 & \\
$21 / 6 / 2006$ & 61,6 & 6,36 & 0 \\
$28 / 6 / 2006$ & 46 & 0 & 1,12 \\
$5 / 7 / 2006$ & 78,4 & 3,78 & 3,36 \\
$12 / 7 / 2006$ & 52,64 & 0 & 0 \\
$19 / 7 / 2006$ & 38,64 & 0 & 0 \\
$26 / 7 / 2006$ & 35,8 & 0,28 & 3 \\
\hline
\end{tabular}




\begin{tabular}{cccc}
\hline \multicolumn{3}{c}{ Nitrato } & \\
\hline Data & Afluente & Efluente R.1 & Efluente R.2 \\
$24 / 5 / 2006$ & 0,526 & 5,14 & 4,6 \\
$31 / 5 / 2006$ & 0,33 & & 5,35 \\
$7 / 6 / 2006$ & & 4,11 & 1,91 \\
$14 / 6 / 2006$ & 0,41 & 7,98 & 8,7 \\
$21 / 6 / 2006$ & 0,02 & 5,77 & 4,77 \\
$28 / 6 / 2006$ & & & \\
$5 / 7 / 2006$ & & & \\
$12 / 7 / 2006$ & & & \\
$19 / 7 / 2006$ & & & \\
$26 / 7 / 2006$ & & & \\
\hline
\end{tabular}

\begin{tabular}{cccc}
\hline \multicolumn{3}{c}{$\begin{array}{c}\text { Fósforo } \\
\text { Total }\end{array}$} & \\
\hline Data & Afluente & Efluente R.1 Efluente R.2 \\
$24 / 5 / 2006$ & & & \\
$31 / 5 / 2006$ & 9,96 & & 4,78 \\
$7 / 6 / 2006$ & 9,14 & & \\
$14 / 6 / 2006$ & 10,37 & 3,47 & \\
$21 / 6 / 2006$ & 9,81 & & \\
$28 / 6 / 2006$ & 7,9 & 3,3 & \\
$5 / 7 / 2006$ & 10,22 & 4,58 & 6,06 \\
$12 / 7 / 2006$ & 8,28 & 0,95 & 1,33 \\
$19 / 7 / 2006$ & 7,62 & 2,71 & \\
$26 / 7 / 2006$ & 6,94 & & 4,67 \\
\hline
\end{tabular}

Fósforo

Solúvel

\begin{tabular}{cccc}
\hline Data & Afluente & Efluente R.1 & Efluente R.2 \\
$24 / 5 / 2006$ & & & \\
$31 / 5 / 2006$ & 5,79 & & 0,44 \\
$7 / 6 / 2006$ & 6,79 & & \\
$14 / 6 / 2006$ & 6,47 & 2,72 & \\
$21 / 6 / 2006$ & 6,78 & & \\
$28 / 6 / 2006$ & 5,12 & 1,46 & 3,4 \\
$5 / 7 / 2006$ & 8,61 & 3,83 & 4,51 \\
$12 / 7 / 2006$ & 6,16 & 0,65 & 1,41 \\
$19 / 7 / 2006$ & 4,7 & 2,09 & 3,51 \\
$26 / 7 / 2006$ & 3,09 & & \\
\hline
\end{tabular}




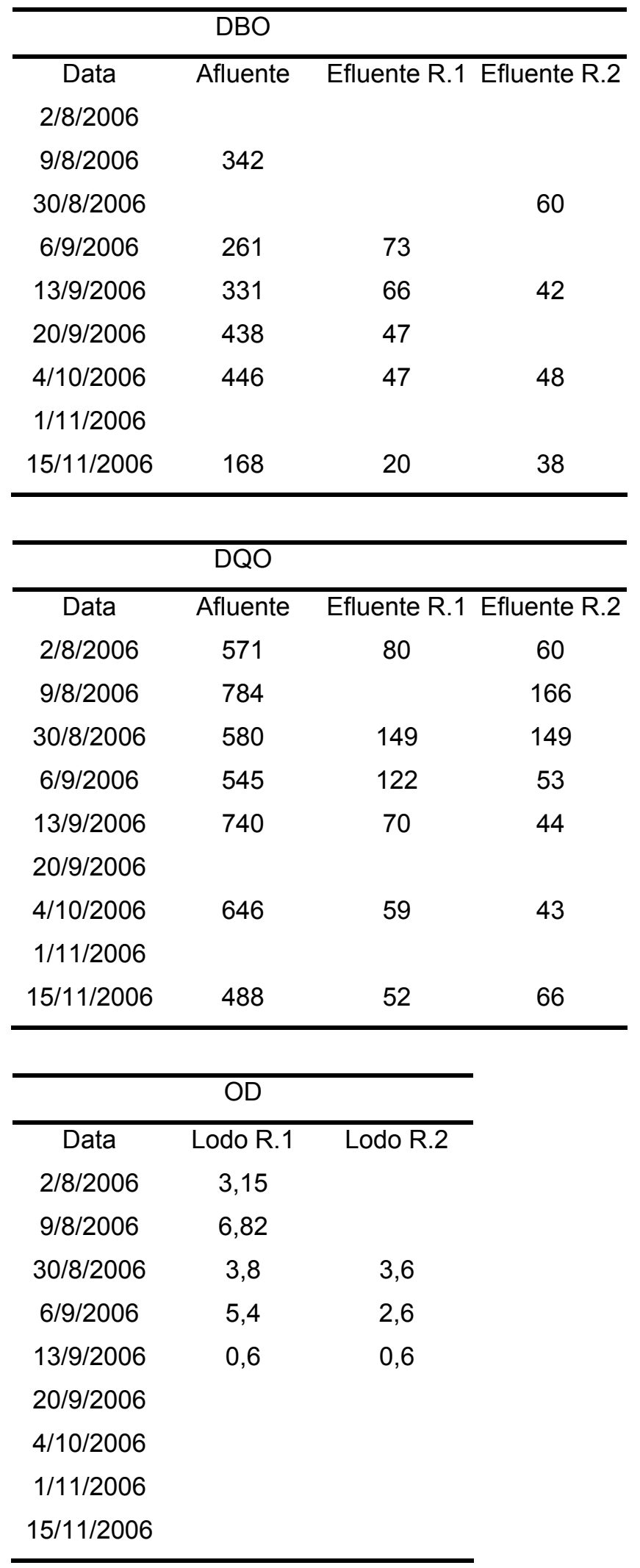




\begin{tabular}{|c|c|c|c|c|c|}
\hline & Temperatura & & & & \\
\hline Data & Afluente & Lodo R.1 & Lodo R.2 & Efluente R.1 & Efluente R.2 \\
\hline $2 / 8 / 2006$ & & 17 & & 17,5 & 18 \\
\hline \multicolumn{6}{|l|}{$9 / 8 / 2006$} \\
\hline $30 / 8 / 2006$ & 18 & 19 & 19 & 20 & 19 \\
\hline $6 / 9 / 2006$ & 16 & 18 & 18 & 18 & 18 \\
\hline 13/9/2006 & 22 & 22 & 24 & 22 & 22 \\
\hline $20 / 9 / 2006$ & & 22 & 22 & 23 & 22 \\
\hline $4 / 10 / 2006$ & & 23 & 23 & & \\
\hline \multicolumn{6}{|l|}{$1 / 11 / 2006$} \\
\hline $15 / 11 / 2006$ & 22 & & 21 & 22 & \\
\hline
\end{tabular}

\begin{tabular}{cccccc}
\hline \multicolumn{3}{c}{$\mathrm{pH}$} & \multicolumn{5}{c}{} \\
\hline Data & Afluente & Lodo R.1 & Lodo R.2 & Efluente R.1 & Efluente R.2 \\
$2 / 8 / 2006$ & 6,6 & & 6,98 & 6,7 & 6,57 \\
$9 / 8 / 2006$ & & & & & \\
$30 / 8 / 2006$ & 7,3 & 6,9 & 6,62 & 6,89 & 6,4 \\
$6 / 9 / 2006$ & 7,2 & 6,4 & 6,6 & 6,3 & 6,5 \\
$13 / 9 / 2006$ & 7,22 & 6,8 & & 6,8 & 6,8 \\
$20 / 9 / 2006$ & 7,2 & 6,7 & 6,8 & 6,71 & 7 \\
$4 / 10 / 2006$ & & 6,53 & 6,63 & & 6,7 \\
$1 / 11 / 2006$ & & & & & \\
$15 / 11 / 2006$ & 7,51 & & 7,26 & 6,95 & \\
\hline
\end{tabular}

\begin{tabular}{cccc}
\hline \multicolumn{3}{c}{ Alcalinidade } & \\
\hline Data & Afluente & Efluente & Efluente R.2 \\
R.1 & \\
$2 / 8 / 2006$ & 175 & 53 & 40 \\
$9 / 8 / 2006$ & & & \\
$30 / 8 / 2006$ & 159 & 110 & 65 \\
$6 / 9 / 2006$ & 170 & 66 & 56 \\
$13 / 9 / 2006$ & 225 & 95 & 103 \\
$20 / 9 / 2006$ & 171 & 5 & 9,2 \\
$4 / 10 / 2006$ & 193 & 67 & 84 \\
$1 / 11 / 2006$ & & & \\
$15 / 11 / 2006$ & 225 & 187 & 114 \\
\hline
\end{tabular}




\begin{tabular}{cccccc}
\hline \multicolumn{7}{c}{ SST } & \multicolumn{5}{c}{} \\
\hline Data & Afluente & Lodo R.1 & Lodo R.2 & Efluente R.1 & Efluente R.2 \\
$2 / 8 / 2006$ & 332 & 2260 & 3608 & 88 & 54 \\
$9 / 8 / 2006$ & & & & & \\
$30 / 8 / 2006$ & 212 & 2468 & 3024 & 132 & 140 \\
$6 / 9 / 2006$ & 376 & 2840 & 3448 & 72 & 28 \\
$13 / 9 / 2006$ & 276 & 2884 & 3220 & 40 & 10 \\
$20 / 9 / 2006$ & 656 & 3056 & 3352 & 52 & \\
$4 / 10 / 2006$ & 296 & 2948 & 3164 & 32 & 8 \\
$1 / 11 / 2006$ & 300 & 4236 & 3804 & 80 & 160 \\
$15 / 11 / 2006$ & 236 & 2136 & 3720 & 52 & \\
\hline
\end{tabular}

\begin{tabular}{cccccc}
\hline \multicolumn{7}{c}{ SSV } & \multicolumn{3}{c}{} \\
\hline Data & Afluente & Lodo R.1 & Lodo R.2 & Efluente R.1 & Efluente R.2 \\
$2 / 8 / 2006$ & 232 & 1448 & 2424 & 56 & 36 \\
$9 / 8 / 2006$ & & & & & \\
$30 / 8 / 2006$ & 172 & 1812 & 2156 & 96 & 100 \\
$6 / 9 / 2006$ & 208 & 1900 & 2208 & 60 & 24 \\
$13 / 9 / 2006$ & 228 & 2020 & 2196 & 32 & 10 \\
$20 / 9 / 2006$ & 428 & 2132 & 2224 & 52 & \\
$4 / 10 / 2006$ & 264 & 2020 & 2184 & 32 & 8 \\
$1 / 11 / 2006$ & 160 & 2724 & 2496 & 60 & 112 \\
$15 / 11 / 2006$ & 120 & 1424 & 2452 & 36 & \\
\hline
\end{tabular}

\begin{tabular}{cccccc}
\hline \multicolumn{7}{c}{ SSF } & \multicolumn{5}{c}{} \\
\hline Data & Afluente & Lodo R.1 & Lodo R.2 & Efluente R.1 & Efluente R.2 \\
$2 / 8 / 2006$ & 100 & 812 & 1184 & 32 & 18 \\
$9 / 8 / 2006$ & & & & & \\
$30 / 8 / 2006$ & 40 & 656 & 868 & 36 & 40 \\
$6 / 9 / 2006$ & 168 & 940 & 1240 & 12 & 4 \\
$13 / 9 / 2006$ & 48 & 864 & 1024 & 8 & 0 \\
$20 / 9 / 2006$ & 228 & 924 & 1128 & 0 & \\
$4 / 10 / 2006$ & 32 & 928 & 980 & 0 & 0 \\
$1 / 11 / 2006$ & 140 & 1512 & 1308 & 20 & 48 \\
$15 / 11 / 2006$ & 64 & 712 & 1268 & 16 & \\
\hline
\end{tabular}




\begin{tabular}{cccc}
\hline \multicolumn{4}{c}{ Nitrogênio } \\
Total & & \\
\hline Data & Afluente & Efluente R.1 & Efluente R.2 \\
$2 / 8 / 2006$ & 69,4 & 14 & 7,84 \\
$9 / 8 / 2006$ & & & \\
$30 / 8 / 2006$ & 67,2 & 33,6 & 20,16 \\
$6 / 9 / 2006$ & 65,52 & 22,4 & 5,6 \\
$13 / 9 / 2006$ & 71,12 & 16,24 & 15,68 \\
$20 / 9 / 2006$ & 73,92 & 7,2 & \\
$4 / 10 / 2006$ & 79,5 & 11,76 & \\
$1 / 11 / 2006$ & & & \\
$15 / 11 / 2006$ & 72,8 & 26,8 & 43,12 \\
\hline
\end{tabular}

\begin{tabular}{cccc}
\hline \multicolumn{4}{c}{ N-Amoniacal } \\
\hline Data & Afluente & Efluente R.1 & Efluente R.2 \\
$2 / 8 / 2006$ & 45,9 & 3,9 & 0,4 \\
$9 / 8 / 2006$ & & & \\
$30 / 8 / 2006$ & 43 & 21,14 & 7,98 \\
$6 / 9 / 2006$ & 43 & 10,64 & 0,28 \\
$13 / 9 / 2006$ & 60,48 & 11,06 & 11,76 \\
$20 / 9 / 2006$ & 37,52 & 0,42 & 9,8 \\
$4 / 10 / 2006$ & 53,2 & 6,4 & 10,9 \\
$1 / 11 / 2006$ & & & \\
$15 / 11 / 2006$ & 47 & & \\
\hline
\end{tabular}

\begin{tabular}{cccc}
\hline \multicolumn{4}{c}{ Fósforo } \\
Total & & \\
\hline Data & Afluente & Efluente R.1 & Efluente R.2 \\
$2 / 8 / 2006$ & 6,45 & 2,85 & 4,66 \\
$9 / 8 / 2006$ & & & \\
$30 / 8 / 2006$ & 6,15 & 2,72 & 2,84 \\
$6 / 9 / 2006$ & 5,67 & & 0,44 \\
$13 / 9 / 2006$ & 8,68 & 1,32 & 0,59 \\
$20 / 9 / 2006$ & 6,93 & 1,44 & \\
$4 / 10 / 2006$ & 8,84 & 2,57 & 1,73 \\
$1 / 11 / 2006$ & & & \\
$15 / 11 / 2006$ & 7,26 & 1,8 & 2,09 \\
\hline
\end{tabular}




\begin{tabular}{cccc}
\hline & $\begin{array}{c}\text { Fósforo } \\
\text { Solúvel }\end{array}$ & & \\
\hline Data & Afluente & Efluente R.1 & Efluente R.2 \\
$2 / 8 / 2006$ & 3,54 & 1,19 & 2,8 \\
$9 / 8 / 2006$ & & & \\
$30 / 8 / 2006$ & 3,86 & 0,09 & 0,16 \\
$6 / 9 / 2006$ & 2,72 & & 0,16 \\
$13 / 9 / 2006$ & 5,89 & 0,4 & 0,12 \\
$20 / 9 / 2006$ & 3,8 & 0,38 & 0,05 \\
$4 / 10 / 2006$ & 5,79 & 1,14 & 0,5 \\
$1 / 11 / 2006$ & & & \\
$15 / 11 / 2006$ & 3,05 & 0,12 & 0 \\
\hline
\end{tabular}

